\title{
WestVirginiaUniversity
}

THE RESEARCH REPOSITORY @ WVU

Graduate Theses, Dissertations, and Problem Reports

2021

\section{Innovations in Money and Banking Markets}

\author{
Eduardo Guimaraes Minuci \\ West Virginia University, egm0007@mix.wvu.edu
}

Follow this and additional works at: https://researchrepository.wvu.edu/etd

Part of the Finance Commons, and the Macroeconomics Commons

\section{Recommended Citation}

Guimaraes Minuci, Eduardo, "Innovations in Money and Banking Markets" (2021). Graduate Theses, Dissertations, and Problem Reports. 8103.

https://researchrepository.wvu.edu/etd/8103

This Dissertation is protected by copyright and/or related rights. It has been brought to you by the The Research Repository @ WVU with permission from the rights-holder(s). You are free to use this Dissertation in any way that is permitted by the copyright and related rights legislation that applies to your use. For other uses you must obtain permission from the rights-holder(s) directly, unless additional rights are indicated by a Creative Commons license in the record and/ or on the work itself. This Dissertation has been accepted for inclusion in WVU Graduate Theses, Dissertations, and Problem Reports collection by an authorized administrator of The Research Repository @ WVU.

For more information, please contact researchrepository@mail.wvu.edu. 
Graduate Theses, Dissertations, and Problem Reports

2021

Innovations in Money and Banking Markets

Eduardo Guimaraes Minuci

Follow this and additional works at: https://researchrepository.wvu.edu/etd

Part of the Finance Commons, and the Macroeconomics Commons 


\title{
Innovations in Money and Banking Markets
}

\section{Eduardo Guimarães Minuci}

\author{
Dissertation submitted to the \\ John Chambers College of Business and Economics \\ at West Virginia University \\ in partial fulfillment of the requirements for the degree of \\ Doctor of Philosophy \\ in \\ Economics
}

Scott Schuh, Ph.D., Committee Chairperson

Joshua Hall, Ph.D.

Arabinda Basistha, Ph.D.

Laura Ullrich, Ph.D.

Department of Economics

Morgantown, West Virginia

2021

Keywords: Banking, Money, Transaction Balances, Regional Banking, Community Banks, Cost Efficiency.

Copyright @ 2021 Eduardo Guimarães Minuci 


\title{
Abstract \\ Innovations in Money and Banking Markets
}

\author{
Eduardo Guimarães Minuci
}

The U.S. banking industry has experienced several technological and banking regulatory changes in the past two decades. This dissertation is composed of three papers that review and investigate how these banking and technological innovations have impacted depositors, bank provision of monetary assets, and bank performance. The order in which the papers are presented follows the order in which they were produced as the production of one paper helped spark ideas that led to the next.

Motivated by the fact that money has become more heterogeneous in terms of its returns, Chapter 1 focus on innovations in money markets by focusing on monetary assets that are used for payment of daily transaction in an economy, also called transaction balances. This chapter surveys and critically evaluates the historical regulatory, financial, and technological innovations that have occurred since the 1970s that have caused the definition of U.S. transaction balances to be a dynamic rather than a static process. The review concludes by analyzing the potential challenges this research field faces a head, with the main topic being the social welfare consequences of the developments of the current payment system in the United States.

Given the different types of deposit accounts banks can offer highlighted in the first chapter, this raises the question: do banks operating in different regions offer different deposit accounts? Chapter 2 explores this by examining differences in the composition and behavior of West Virginia banks. The focus on WV is motivated by the relatively weak economic growth the state has experienced. Many factors potentially contribute to this fact, but little research has examined the role of financial s ervices. This paper uses micro banking data to document how WV banks differ from their U.S. counterparts and assess whether differences can be explained by the composition of banks in the state. Despite experiencing faster banking consolidation, West Virginia still has more and smaller banks that are less efficient and p rofitable. WV banks also have customers that favor lower-risk, lower-return deposits, and managers who rely heavily on lower-risk, lower-return real estate loans (mostly 1-4 unit residential). Other states have banks with considerable heterogeneity in real estate loan shares, but most of these financial outcomes are not explained well by observable bank and regional characteristics. Other factors are needed to explain financial heterogeneity of banks across states; unusually high risk aversion may explain the economically distinct banking strategies and low returns of WV banks.

Motivated by the findings from Chapter 2 of the presence of interesting differences in financial behavior of banks across U.S. states, this paper more formally quantifies them by exploring differences in one dimension (cost efficiency) and showing where they emerge g eographically. Cost efficiency is explored due to its link to the ability of banks to survive and provide liquidity services to their clients (Assaf et al., 2019). This performance measurement is estimated at the bank-level 
using a parametric cost frontier methodology, which is then aggregated at the state-level to generate performance measures for U.S. state banking markets. Given the output quality homogeneity imposed by this methodology, this research focuses on U.S. community banks (CBs) only, which are local U.S. banks that specialize in relationship loans. When compared to the findings from two decades ago from Berger and Mester (1997), the bank-level results show a significant decrease in the average cost efficiency of U.S. banks relative to the best-practice bank in that respective period. At the state-level, a wide gap between top and poorly performing local banking markets is found. This is a result subsequent work will continue to investigate, given that it has the potential to partially explain differences in economic growth and labor market outcomes across U.S. states. 


\section{Acknowledgments}

I want to take a moment to express my special appreciation to family, friends, and professionals who were essential in my life during this $\mathrm{PhD}$ program. Most importantly, I want to thank my wife Tiffany and Charlee as they have been my rock every day. They give me strength to face the tough parts of life as they are constantly reminding me the blessing that life with them is, and for that I will always be thankful to them.

I also want to thank my parents, my brother, Tuca, my grandparents, the Greeleys, the Laments, and all my other beloved family members in Brazil. This $\mathrm{PhD}$ has taught me a lot about the value of family in one's life and I wanted to thank them for always supporting me and being there for me.

I definitely want to highlight how thankful I also am to all my amazing friends for always supporting and motivating me during the moments of uncertainty in life. I am always amazed of how lucky I am to have such amazing friends. They are a huge part of why I can keep a positive mindset and I definitely would not be the person I am today without them being there for me during this process.

A person who I specially want to take a moment to thank is my advisor, Dr. Scott Schuh, for guiding and mentoring me during this entire process. I truly thank him for not only teaching me how to be a researcher, but for also showing me how to balance self-care and family life while still having a successful career. I truly appreciate him taking so much of his time to teach me and for believing in my potential. I hope to one day be able to be as influential on a student's life as he is in mine.

Lastly, I want to take a moment to also thank Joshua Hall, Arabinda Basistha, Laura Ullrich, Bryan McCannon, Zachary Rodriguez, Alexandre Scarcioffolo, Candon Johnson, Margaret Bock, Ben Blemmings, and many others who were present during the presentations of the preliminary results of this study. Their feedback and discussions were a big component in the production of this $\mathrm{PhD}$ dissertation and in my professional development. 


\section{Contents}

$\begin{array}{ll}\text { Abstract } & \text { ii }\end{array}$

Acknowledgments $\quad$ iv

List of Figures $\quad$ viii

$\begin{array}{lc}\text { List of Tables } & \mathbf{x} \\ \end{array}$

1 U.S. Transaction Balances in the New Millennia 1

1.1 Introduction $\ldots \ldots \ldots \ldots \ldots \ldots$

1.2 Money and Transaction Balances in the United States . . . . . . . . . . . . 3

1.3 The Impact of Regulations . . . . . . . . . . . . . . . . 7

1.4 Financial Innovations in the Past 50 Years . . . . . . . . . . . . . . . . . 10

1.5 What's Ahead $\ldots \ldots \ldots \ldots \ldots$

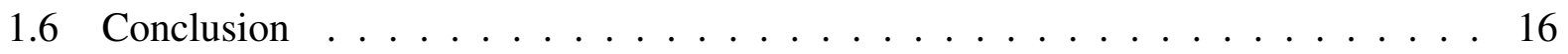

2 How Are West Virginia Banks Different? 20

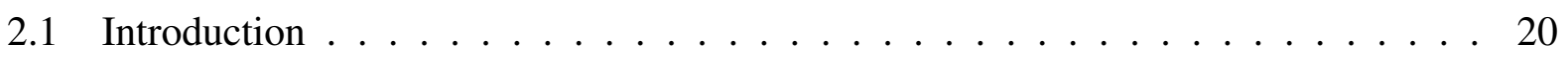

2.2 Literature Review . . . . . . . . . . . . . . . . . . . . 23

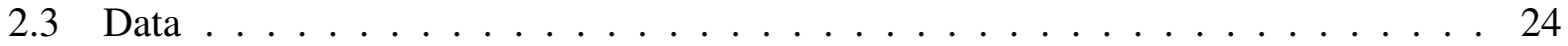

2.4 Banks and Their Markets . . . . . . . . . . . . . . . . . 25

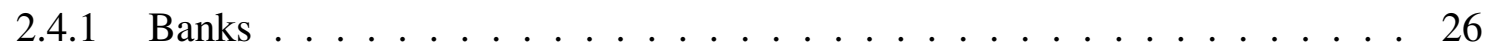


2.4 .2 Definitions . . . . . . . . . . . . . . . . 27

2.4 .3 Market Composition $\ldots \ldots \ldots \ldots \ldots \ldots$

2.5 Aggregate Banking Activity $\ldots \ldots \ldots \ldots \ldots \ldots$

2.5.1 Empirical Methodology _. . . . . . . . . . . . . . . 30

2.5 .2 Aggregate Evidence $\ldots \ldots \ldots \ldots \ldots \ldots \ldots \ldots$

2.5 .3 Evidence by Market $\ldots \ldots \ldots \ldots$

2.5 .4 Return on Assets . . . . . . . . . . . . . . . . . . 36

2.6 Econometric Models . . . . . . . . . . . . . . . . . . . 37

2.6.1 Regression Specifications _ . . . . . . . . . . . . . . . 37

2.6 .2 Estimation . . . . . . . . . . . . . . . 39

2.7 Results . . . . . . . . . . . . . . . . . . . . . 41

2.7.1 Fixed-effects Models . . . . . . . . . . . . . . . . . . . 41

2.7.2 Mixed-effects Models . . . . . . . . . . . . . . . . . . . 45

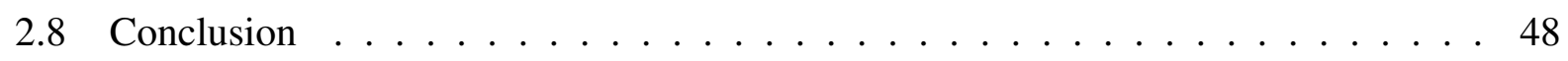

3 A State-Level Analysis of the Cost Efficiency of U.S. Community Banks $\quad 80$

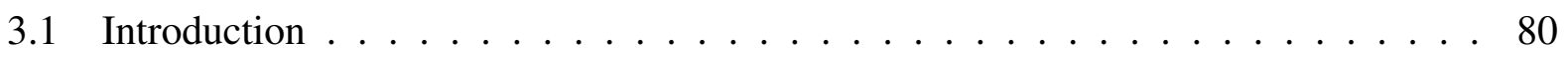

3.2 Literature Review . . . . . . . . . . . . . . . . . . . 83

3.2.1 Cost Efficiency: Banking Application . . . . . . . . . . . . . 83

3.2.2 The Importance of Regional Banking $\ldots \ldots \ldots$

3.3 Data . . . . . . . . . . . . . . . . . 86

3.4 Methodology . . . . . . . . . . . . . . . . . . . . 87

3.4.1 Cost Efficiency Estimation for Banks _ . . . . . . . . . . . . 87

3.5 Results . . . . . . . . . . . . . . . . . . . . . 92

3.5.1 Bank-Level Cost Efficiency Results . . . . . . . . . . . . . . . . 92

3.5.2 Empirical Investigation of Potential Correlates with Cost Efficiency . . . 93

3.5 .3 State-Level Analysis . . . . . . . . . . . . . . . . . 96

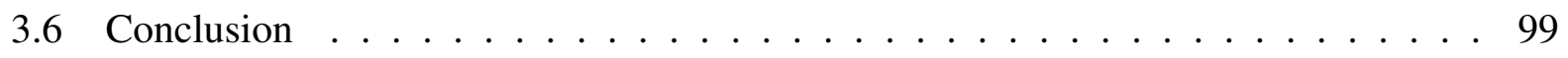


Appendix

G Additional Tables and Figures for Chapter $2 \ldots \ldots$. . . . . . . . . . 120 


\section{List of Figures}

2.1 Number of Banks . . . . . . . . . . . . . . . . . . . . . . 51

2.2 Banks per Capita by Charter, $2017 \ldots \ldots \ldots$

2.3 Distribution of Branches by Asset Size, 2017 . . . . . . . . . . . . . 53

2.4 Composition of WV Banking Industry, $2017 \ldots \ldots \ldots$

2.5 SMB Deposit Shares by State, $2017 \ldots \ldots$. . . . . . . . . . . . . . 55

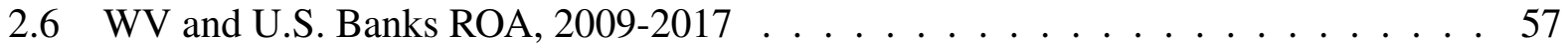

2.7 WV and US* Bank Liabilities by Market, $2017 \ldots \ldots \ldots$

2.8 WV and US* Bank Non-transaction Accounts by Market, 2017 . . . . . . . . . . 59

2.9 WV and US* Bank Assets by Market, $2017 \ldots \ldots$

2.10 WV and US* Bank Revenues by Market, 2017 . . . . . . . . . . . . . . 61

2.11 WV and US* Bank Noninterest Income by Market, 2017 . . . . . . . . . . . 62

2.12 WV and US* Bank ROA by Market, 2009-2017 . . . . . . . . . . . . . 63

2.13 Share of Real Estate Loans by State of Bank HQ, 2017 . . . . . . . . . . . . 75

2.14 Mixed-effects Model Estimates of Real Estate Loan Shares, 2017 . . . . . . . . . 76

2.15 Model Errors in Real Estate Loan Shares, 2017 . . . . . . . . . . . . . . . 77

2.16 Estimated Fixed- and Random-Effects for Real Estate Loans, 2017 . . . . . . . . 78

2.17 Decomposition of Random Effects for Real Estate Loans, 2017 . . . . . . . . . 79

3.1 Histograms of Cost Efficiency of U.S. Community Banks ～. . . . . . . . 105

3.2 State Weighted Average of Cost Efficiency of Community Banks by State . . . . 108 
G.1 WV and US* Bank Expenses by Market, 2017 . . . . . . . . . . . . . . . 120

G.2 WV and US* Interest Rates on Deposits . . . . . . . . . . . . . . 121

G.3 WV and US* Interest Rates on Loans . . . . . . . . . . . . . . . . . . . . 122 


\section{List of Tables}

1.1 Money Demand Literature Papers $\ldots \ldots \ldots$

1.2 Types of Money in the United States $\ldots \ldots \ldots$

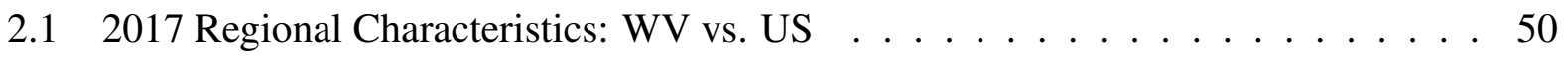

2.2 Financial Statements for U.S. and WV Banks, $2017 \ldots \ldots \ldots$

2.3 Liabilites and Equity $\ldots \ldots \ldots \ldots$

2.4 Domestic Deposits . . . . . . . . . . . . . . . . . . 65

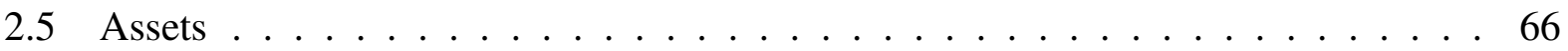

2.6 Real Estate Loans . . . . . . . . . . . . . . . . . . . . . . . . . 68

2.7 Income: Interest and Noninterest . . . . . . . . . . . . . . . . . 69

2.8 Noninterest Income . . . . . . . . . . . . . . . . . . . . . . 71

2.9 Expenses: Interest and Noninterest $\ldots \ldots \ldots \ldots$

2.10 Interest Expenses $\ldots \ldots \ldots \ldots \ldots \ldots$

3.1 Banking Market State-Level Characteristics _ . . . . . . . . . . . . . . 101

3.2 Descriptive Statistics of the Cost Function Main Variables _ . . . . . . . . 102

3.3 Panel Bank-Level Regression Estimates _ . . . . . . . . . . . . . . . . 103

3.4 Cost Efficiency of U.S. Community Banks _ . . . . . . . . . . . . . 104

3.5 Banking and Regional Characteristics of U.S. Community Banks _ . . . . . . 106

3.6 Micro-Level Cost Efficiency of U.S. Banks ～. . . . . . . . . . . . . . . 107

3.7 State-Level Correlation Matrix . . . . . . . . . . . . . . . . . . . . . . 109 
G.1 WV Top 10 Banks by WV Deposits, $2017 \ldots \ldots$. . . . . . . . . . . 123

G.2 Top 10 Banks in the United States by Deposits, 2017 . . . . . . . . . . . . . 124

G.3 Top 10 Banks in WV by Assets, $2017 \ldots \ldots$. . . . . . . . . . . . . . . . . .

G.4 Top 10 Banks in the United States by Assets, 2017 . . . . . . . . . . . . 126

G.1 Data Description . . . . . . . . . . . . . . . . . 127 


\section{Chapter 1}

\section{U.S. Transaction Balances in the New}

\section{Millennia}

\subsection{Introduction}

Transaction balances are the sum of the stock of monetary assets that represent the total day-to-day transactions in an economy. Before the 1970s, according to the critical literature review papers on money demand in Table 1.1, assets used for transaction purposes were traditionally represented by cash and demand deposits. In addition, they were also known for their important role in the formulation of effective monetary policy in the United States. Nonetheless, given financial innovations and regulatory changes experienced by the financial industry, contradicting results were reported by different authors (from Table 1.1) on the effectiveness of measurements are useful monetary policy parameters. As pointed out by Lucas Jr. and Nicolini (2015) and Ball (2012), however, an explanation for these contradicting results comes from differences across studies in defining which monetary assets serve the function of means of payment in the U.S. economy.

This review complements the literature surveys provided by Dalziel (2000) and Lagos et al. (2017). Paul Dalziel surveys the impact of the development of practices of the banking industry has had on monetary theory and policy, while Ricardo Lagos, Guillaume Rocheteau, and Randall 
Wright provide a critical literature review on how to explicitly model liquidity and the acceptability of monetary assets into the exchange process of different economic agents. This paper contributes to the literature by describing which innovations (regulatory, financial or technological) have occurred since the 1970s that have caused the components of the U.S. transaction balances to change.

It is remarkable how much technology has evolved in the past five decades and, thus, not surprising that these advancements have reached financial markets. Certain financial innovations, combined with technological advances, have affected the monetary characteristics of monetary assets by either allowing and improving transfers (monetary and non-monetary) between agents or allowing more illiquid assets or new monetary assets to serve similar function of extremely liquid ones. For instance, developments in payment methods have altered the acceptability of monetary assets between sellers and buyers and, hence, increased their ability to serve the function of medium of exchange. Furthermore, changes in the regulatory environment and emergence of new financial instruments have altered the convenience and costs of transferring funds across different types of deposit accounts. Thus, allowing for interest-bearing assets, such as MMDAs, to serve the purpose of paying for daily transactions.

The definition of transaction balances is a dynamic rather than a static process. Monetary assets used to make day-to-day payments have changed over time due to changes in regulations and financial/technological innovations. Given that these developments tend to have an asymmetric impact on the liquidity characteristics of different monetary assets, they require individuals to reevaluate their wealth portfolio allocation. When aggregated over time, changes in individuals' portfolio allocation of wealth may require a reassessment of which monetary assets should be considered when defining the main types of money being used for transactions in the economy. Thus, this review also highlights the need to update the variable used to identify monetary assets used for transaction purposes in models that include money, such as money-in-utility (MIU), cashin-advance (CIA), and New Monetarist Economics (NME).

This review adds to the strain of literature on money and payment methods by critically evaluating which and how technological, financial, or regulatory innovations in the past five decades 
have altered the definition of transaction balances in the U.S. economy today. The content of this paper addresses the shortcomings of the literature in defining money used for day-to-day transactions, which have arisen from the inability of the components included in the U.S. monetary base to catch up to the pace of technological innovations in financial markets. This review concludes by analyzing the potential challenges this research field faces ahead. The main topics being the social welfare consequences of the developments of the current payment system in the US.

The following section of this review covers the definition of money and transaction balances. Moreover, it also covers the evolution from commodity to fiat money in the United States and explains how monetary aggregates are not able to define transaction balances in the United States anymore. Section 3 explores the regulatory changes which allowed new types of money to emerge and the impact of these developments on the asset portfolio allocation in the US. Section 4 focus on the technological and financial innovations that altered the acceptability and medium of exchange function of traditionally illiquid types of money. Section 5 discusses future important topics for research in this field, and section 6 concludes.

\subsection{Money and Transaction Balances in the United States}

Since transaction balances are a subcategory of money and liquidity, it is important to define these terms. This sections begins exploring the definition of money and ends discussing liquidity.

As introductory economics classes teach, money is an asset that serves three main functions: medium of exchange, unit of account, and store of value. Its most important characteristic is to facilitate the exchange process among economic agents (Lagos et al., 2017). As highlighted by Tobin (1992), money facilitates trade and, hence, allows individuals to achieve a higher standard of living. This can be illustrated by the traditional double coincidence of wants problem, which can be improved when a commonly adopted medium of exchange is introduced. This review will specifically focus on monies which main function is to serve as a medium of exchange for day-today expenses in the US. 
The monetary assets that have served the function of money in the U.S. economy have changed over time. Commodity money was the earliest type of money that emerged in the United States used for day-to-day transactions (Lagos et al., 2017). One of the drawbacks of commodity money is that its value is derived from the intrinsic value of the underlying commodity composing it (e.g., gold, silver, and other precious metals) making it costly to produce and susceptible to large fluctuations in supply or demand. In addition, given that the supply of commodity money is dependent on the quantity of its underlying commodity, this type of money limits the monetary authority of a central bank over determining the quantity of money in circulation in the economy.

During the Great Depression the drawbacks of commodity money became evident resulting in the emergence of fiat money. This took place when Congress, in 1933, declared all coin and currency issued by the Federal Reserve to be a legal tender in the US. Hence, over the next five decades, the value of the U.S. dollars transitioned from being tied to the value of gold to simply being tied to the belief of market participants on the ability of the U.S. dollar money to maintain its purchasing power in the near future. Thus, the economy slowly transitioned from using commodity to fiat money, a type of medium of exchange which is intrinsically useless and inconvertible (Wallace, 2018).

Different from value origination, distinguishing money based on its form does not limit the ability of an asset to serve for transaction purposes. For instance, in terms of form, U.S. transaction balances are composed of both physical and electronic monetary assets. Physical money has the main four functions of money and can be physically held by its possessor. On the other hand, electronic money (also called virtual money or e-money) also possesses these four functions, but it exists only virtually. Electronic money can be either be sovereign or privately issued.

Private e-monies are issued by private companies, which is different from sovereign money since its created by a central bank. The acceptability and relevance of private monies is exacerbated for less developed economies due to the lack of trust of its economic agents in the ability of the country's sovereign currency to hold maintain value over time, which leads them to opt for the use of a relatively more stable private currency. For instance, Jack et al. (2010) and Ahmad et al. 
(2020) report the emergence of MPESA, a private money, as the dominantly used currency in Kenya. Given the lack of data on the share of U.S. transactions that use cryptocurrencies as a medium of exchange and the share of U.S. sellers which accept them as a method of payment, this is an area of study future research must address. In the past, the definition of transaction balances in the United States was linked to the definition of U.S. monetary aggregates. Walter (1989) provides explanations to the origin and evolution of monetary aggregates in the US. In 1944, the Federal Reserve began published information on the total stock of money called M1, with the intent to provide information to the U.S. private sector on the total supply of money in the economy. Traditionally, M1 was representative of the total U.S. transaction balances since it is composed of noninterest-bearing monetary assets (such currency, ${ }^{1}$ demand deposits at commercial banks, and traveler's checks) and interest-bearing accounts which do not impose restrictions on depositors on the number transactions they are allowed to do in a given time period (such as NOW accounts). Nonetheless, over time monetary assets not included in M1 began to gain the ability to also serve transaction purposes.

In addition to M1, the Federal Reserve also began publishing data on a monetary aggregate called M2 in 1971 (Walter, 1989). ${ }^{2}$ This new monetary aggregate arose especially due to the growing importance for monetary policy analysis of less liquid monetary assets that served the function of store of value in the United States (Adrian and Shin, 2009). M2 is defined by the sum of M1, savings deposits (including money market deposit accounts), and small-denomination time deposits, with some exceptions. M2 components not in M1 include were traditionally relatively less liquid but offered higher returns, thus, serving well the function of store of value of money. Over time, however, developments in payment methods and technology have altered liquidity and acceptability characteristics of some of these monetary assets. This study contributes to the literature on money and payment methods by reviewing what has changed in the past five decades

\footnotetext{
${ }^{1}$ Currency here refers to currency that is specifically outside the U.S. Treasury, Federal Reserve Banks, and the vaults of depository institutions.

${ }^{2}$ The Federal Reserve also publishes data on additional monetary aggregates such as M3 and M4; however, given the focus of this review on transaction balances, only the two narrowest U.S. monetary aggregates, M1 and M2, are discussed in this review.
} 
that has led M1 to not fully capture total transaction balances in the U.S. economy as it did in the 1970s.

To determine which monetary assets should be considered part of the U.S. transaction balances this paper uses a benchmark based on how close of a substitute a monetary asset is to cash and demand deposits. This seems like a feasible benchmark given that these assets have been the most used type of monies for transaction purposes in the United States according to data from the Survey of Consumer Payments Choice (Foster et al., 2020). Two important dimensions of comparison in this benchmark are (1) its acceptability among buyers and sellers as method of payment, and (2) the liquidity characteristics of a monetary asset. Acceptability will be further discussed in section 4 with the development of new payment methods. The remaining of this section focus on describing liquidity and its importance in the wealth portfolio allocation of depositors.

Lagos et al. (2017) and Burdett et al. (2017), by modeling the exchange process across economic agents explicitly, show that the monetary characteristics of an asset are dimensions necessary to evaluate the comparability of different monetary instruments. They define liquidity to be an essential parameter for this analysis. Liquidity describes how easy an asset can be converted into cash and therefore has a direct effect on the ability of monetary assets to serve as the source of funds for daily transactions (Greenbaum et al., 2019). Demand deposits and currency are the most liquid types of money in the United States since they can be instantly converted into cash at par.

The incentive to hold relatively illiquid monetary assets comes from their ability to generate positive returns over time. A trade-off is usually observed between the return on a monetary asset and its liquidity characteristics. To earn higher returns, banks impose certain requirements that reduce the easiness (the speed) of converting such assets into cash. If the requirements set by the bank over an account are broken, a fee or loss in interest earned is levied. For instance, savings accounts and Money Market Deposit Accounts (MMDAs), which are offered by banks, tend to limit depositors to a maximum of six transactions per month before facing a penalty fee for moving funds "in excess." Other requirements faced by depositors holding these more illiquid types of accounts include a minimum balance necessary to the keep in the account, and the requirement of 
providing the bank with at least a week (or 30 days) pre-notice prior to withdrawing a significant amount of funds from the account. It is important to highlight that these types of monies are very heterogeneous across different banks despite having similar names; thus, restrictions vary across accounts and banks. Table 1.2 lists the main monetary assets in circulation which are used for transaction purposes in the U.S. economy. Moreover, the table also reports information which monetary aggregate each asset belongs to, and what restrictions explain their imperfect substitutability with cash. For a list of all monetary assets in the U.S. economy, including monetary assets not used for transactions, please refer to Barnett et al. (1992).

\subsection{The Impact of Regulations}

One of the time-variant parameters that have impacted what we define as money in circulation in the United States is the institutional environment faced by the banking industry. For instance, over the past five decades there have been several major policy changes, which led and allowed financial institutions to grow and develop new monetary assets for its customers. Hence, these regulatory changes deserve special attention since they either directly or indirectly have impacted the creation and the ability of different monetary assets to function as a medium of exchange and to store value over time.

The impact that policy has on defining what is the commonly accepted money in an economy is not an innovation of the current economic system. In the early 1700s in England, the master of the mint unintentionally enabled a policy which pushed the gold to new highs, forcing silver coins out of circulation, and lead the British to the gold standard (Tobin, 1992). Nonetheless, the more recent impact of regulations on the U.S. monetary base has been slower and less emphasized by policymakers. For instance, the first policy with major impact on U.S. monetary assets was the Depository Institutions Deregulation and Monetary Control Act of 1980 (Sherman, 2009). This act signed by President Jimmy Carter called for a phase-out of interest rate ceilings on deposit accounts, which was done over a period of six years. Prior to 1980, savings accounts interest rates 
were capped by law, hence most investors had to search for alternative investment opportunities in the market. This act allowed banks to offer higher returns on savings accounts, which aimed to incentivize savings in the economy and altered the store of value characteristics of interest-bearing bank deposit accounts.

This deregulatory pressure which started with the stagflation period experienced in the late 1970s also led to the creation of new monetary assets. To reduce the opportunity cost of holding cash under a period of high interest rates, President Reagan signed the Garn-St. Germain Depository Institutions Act in 1982. This regulatory change allowed commercial banks and thrifts to create and offer Money Market Deposit Accounts (MMDAs) and NOW accounts to its clients. These are deposit accounts, which insured by the FDIC, pay a "money market" rate making them competitive with other investment opportunities such as treasury bills. Despite the higher return, these accounts have restrictions on depositor withdrawal activity that are stricter than the ones imposed by traditional savings accounts. Furthermore, this regulation also allowed bank holding companies to offer discounts on brokerage services, which allowed customers to more easily shift funds from money to money like (less liquid monetary asset) instruments.

Now that banks were allowed to further develop interest-bearing deposit accounts, they only needed opportunities to grow. These opportunities came with the Fed decisions related to Section 20 Subsidiaries in 1987, the Riegle-Neal Interstate Banking and Branching Efficiency Act of 1994, the reinterpretations of the Glass-Steagall Act in 1996, and the Gramm-Leach-Bliley Act of 1999. These polices not only impacted the average size of banks and the competition they faced in the markets they operated, but also their ability to financially innovate (Frame and White, 2004).

Hannan and McDowell $(1984,1987)$ using the conditional probability of a bank adopting automated teller machines (ATM) as a proxy for a bank's financial innovation, show that bank size, bank holding company affiliation, bank product mix, and local competition (whether rival bank in area has adopted ATM) influence the development/adoption of new technologies. Hence, regulatory changes that incentivize/allow banks to grow and expand are positively indirectly linked with the ability of banks to financially innovate. Given that these innovations have asymmetrically 
altered the liquidity characteristics of monetary assets and their ability to serve as a direct medium of exchange to depositors, they have consequently impacted the main types of monetary assets in circulation in the U.S. economy.

So the question is how did these regulatory changes allowed banks to grow faster? The Fed decisions in 1987, for instance, allowed BHCs to start underwriting corporate and other nongovernment securities for banks. This policy affected both the size of security markets and the ability of banks to diversify their investments and grow. Moreover, the Riegle-Neal Act eliminated previous restrictions on interstate banking and branching allowing banks to expand geographically. This regulatory change led to a change in the market composition of the banking industry since markets now faced the presence of both large multi-market ${ }^{3}$ banks and smaller single-market banks. The reinterpretations of the Glass-Steagall Act also deserve attention since they enabled banks to provide investment services and attract more depositors. These began in 1996 and ended with the complete phase-out of this Act in 1999 with the Gramm-Leach-Bliley Act.

Lastly, there was the repeal of the Regulation Q in 2011. Regulation Q was a Federal Reserve Board rule that prohibited banks from paying interest on demand deposits. The Regulation $\mathrm{Q}$ was passed with the Glass-Steagall Act of 1933 with the goal to decrease loan sharking, consequently reducing bank risk, and to motivate consumers to move funds into money market funds. Regulation Q was repealed by the Dodd-Frank Wall Street Reform and Consumer Protection Act of 2010, which removed remaining restrictions on banks offering interest on demand deposits; nonetheless, it still kept restrictions on number of transfers depositors are allowed to have per month in their interest-bearing accounts. This policy intended to control credit illiquidity and promote an increase in reserves. One of its outcomes, however, was an increase in the ability of some of the most liquid U.S. monetary assets to better function as a store of value.

The regulatory changes highlighted in this section made banks to be more likely to innovate and altered both the medium of exchange and store of value characteristics of different monetary assets. They impacted both the ability of banks and financial institutions to create new monetary assets

\footnotetext{
${ }^{3}$ Multi-market here refers to a bank which operates in more than one state.
} 
and make their liquid assets available as a direct medium of exchange through the developments of new payment methods and mobile banking platforms. As stated by Humphrey et al. (2001), the larger variety of monetary instruments allow investors to better allocate their financial resources and, thus, potentially achieve higher utility levels.

The following section of this paper will further define and describe the financial innovations that marked this period. Moreover, it will also summarize the most recent empirical results on the U.S. consumer payment choices which are directly linked to the definition of the components of the U.S. monetary base elaborated in this study.

\subsection{Financial Innovations in the Past 50 Years}

In this paper the term financial innovation "represents something new that reduces costs, reduces risks, or provides an improved product/service/instrument that better satisfies participants' [bank customers'] demands" (Frame and White, 2004). The first financial innovation which deserves attention since the 1970s is the development of automated teller machines (ATMs). This innovation reduced the cost of production for financial institutions over time (Humphrey et al., 2001) and, similar to checks, incentivized individuals to hold less cash in their wallets (Berger, 2003). Depositors now faced lower transaction costs to withdraw money from their deposit accounts since the availability of ATMs increased the likelihood of one being near his/her bank branch or an ATM machine when needing to withdraw money (Frame and White, 2004). This innovation was extremely important before the 2000s when debit cards were not commonly accepted by sellers. Nonetheless, as technology evolved in the United States over time and banking and seller payment systems became more dependent on computers, this environment did not last long.

The most relevant technological innovations were the development of the Internet in the early 2000s and the development of the electronics such as computers and mobile phones. Both had a huge impact in the convenience of using different payment methods for consumers. For instance, the Internet fueled globalization which increased communication and increased labor productivity 
generating more opportunities to firms, including technological and financial, to research and innovate. Moreover, the Internet and computerization of the banking industry increased the provision of internet services (electronic bill payment), direct deposit options, and an increase in the speed of transfers of money (Berger, 2003). Other types of electronic transactions that already existed include FedWire and Automated Clearing House services. However, the Internet significantly lowered the costs of transaction related to using such services. Hence, as computers and cell phones became more accessible and sophisticated, financial innovation led to the emergence of mobile banking services. ${ }^{4}$

The development of mobile banking services was extremely important since it increased the convenience for depositors to manage their funds and transfer money across their own accounts, which could now be done remotely. In addition, they also facilitated/incentivized investment and savings by lowering the cost of gathering information and creating platforms where investors could choose from different investment tools from the comfort of their homes (Ouma et al., 2017). Combined with a regulatory environment that allowed banks to grow and expand, these technological innovations led financial institutions to develop new payment methods to attract more depositors and aim to reduce banks' expenses. Recently, the Fed has been working on creating a faster payments system called FedNow for retail payments that is essentially instantaneous (within day clearing and settlement). ${ }^{5}$

The development of new payment methods can have a similar impact on the wealth portfolio allocation of individuals if the new payment methods lead to a reallocation of funds across different deposit accounts. This is due to the effects these innovations have on the convenience and incentives/costs for consumers and sellers to use different forms of funds to pay for daily transactions, which as highlighted by Schuh and Stavins (2010) are the most important determinants of payment use.

\footnotetext{
${ }^{4}$ Other technological developments similar to mobile banking include Venmo, Zelle, Cash App, among other platforms. Nonetheless, these platforms are not technically allowed to be used for transactions, only transfer of funds among different individuals; hence, since it does not alter the money in circulation in the United States it will not be a focus of this study.

${ }^{5}$ For more info on FedNow please refer to https://www.federalreserve.gov/newsevents/pressreleases/ other20190805a.htm
} 
It is important to properly distinguish between monies and payment methods (Tobin, 1992), which is a concept some economists do not recognize yet. Fujiki and Tanaka (2009) and Singh (1999, 2004), for instance, consider ATM payments and Electronic Funds Transfer at Point of Sale (EFTPOS), such as debit cards, as money. They do not recognize that both are instruments to access an agent's checkable deposit account and should be considered a form of electronic payment method, instead. Other forms of payment methods that can be confused with types of money are checks, money orders, online banking bill pay, and credit cards. ${ }^{6}$ The distinction between money and payment methods is important since technological innovations can affect them differently.

The most important payment methods used by consumers in the past decades are cash payments, checks, debit cards, and credit cards (Schuh and Stavins, 2010). Nonetheless, debit and credit cards have gained a considerable share of the market for payment methods in the most recent decade as shown by the report provided by Foster et al. (2020). These authors provide a summary of consumer behavior based on data from the Survey of Consumer and Payment Methods. Ching and Hayashi (2010), Simon et al. (2010), Carbó-Valverde and Liñares-Zegarra (2011), Arango et al. (2015), and David et al. (2016) show that once card payments are generally accepted by sellers, there is a general negative impact of consumer debit and credit cards usage on the demand for cash.

The benefit of the use of debit cards come from an increase in security over one's deposits, which comes from one not necessarily having to carry large amounts of cash for daily purchases. Both debit and credit cards also provide a certain level of security by requiring cardholders to enter their PIN number (password) or sign a proof of receipt when a transaction is placed using such payment method. In addition, both debit and credit cards facilitate the ability of buyers and sellers to engage in non-in-person (online or mobile) transactions. Thus, the online shopping market (ecommerce) deserves attention in this study given the fast recent growth this market in the past 10 years, as reported by the U.S. Census Bureau in the quarterly retail e-commerce sales of $2020 .^{7}$ Online payment methods dominate the transactions on ecommerce due to a certain "oligopoly"

\footnotetext{
${ }^{6}$ Credit cards deserve special attention given that they are forms of debt (Schuh and Stavins, 2010).

${ }^{7}$ All U.S. Census retail e-commerce reports can be found at http://www.census.gov/retail.
} 
they have over such market. This is because the alternative payment method would be to send a cash or check through the mail, which does not provide the same level of security to neither borrowers nor sellers.

Nonetheless, online payment instruments also gained importance on in-person transactions due to the price incentives offered specially to credit cardholders. Banks have incentivized individuals to use electronic types of payments since they often cost only a third to one-half of the cost of paperbased transactions (Humphrey et al., 2001). Thus, this increase in acceptance of these payment methods by sellers are a result of both nonprice and price incentives offered by banks, such as convenience and marketing for sellers, ${ }^{8}$ and cash back rewards for consumers Arango et al. (2015).

Credit cards are a type of payment used by consumers which has gained popularity given opportunity monetary "rewards" they provide and the emergence of mobile transfer platforms. The technological and financial innovations experienced by the banking industry also generated technologies which facilitated the exchange of information between borrowers and sellers. For instance, "information exchange" were created, which "are intermediaries through which banks and other creditors share data relevant to the creditworthiness of loan applicants" (Berger, 2003). These informational exchange innovations helped fuel the growth of the credit card loan industry, which to attract more customers began offering rewards and incentives for customers who adopted such payment methods (Schuh et al., 2013).

Nonetheless, not all credit cardholders have the ability to take advantage of these rewards since the access to these services depends on one's credit ratings and financial information. Assuming one is approved to get a credit line that can earn rewards, as one uses their credit card to pay for daily expenses one would earn cash back, airfair miles, travel rewards, among others. ${ }^{9}$ The overall monetary compensation received by each cardholder is then based on the type of the credit line and the type, number, and magnitude of the transactions placed by the cardholder during a billing

\footnotetext{
8 "Nonprice attributes are very important and concern increasing the availability of credit and debit card terminals at the point of sale, expanding the number of firms that can accept electronic bill payments, convincing employees to have their wages deposited electronically, and establishing dispute resolution policies for preauthorized direct debits to compensate for loss of user control over when a debit occurs" (Humphrey et al., 2001).

${ }^{9}$ These include points reward system that allow consumers to trade points for discount on hotels, vacations, restaurants, etc.
} 
cycle.

These credit card price incentives altered the customer cost of using credit cards for daily transactions, but, more importantly, they gave consumers the option to increase the returns on their deposits. Traditionally, due to the instant loss of funds upon the purchase of a good/service and the withdraw restrictions imposed on savings accounts, individuals generally allocated a certain amount of their wealth towards extremely liquid (M1) monies for daily purchases. Nonetheless, different from debit cardholders, credit cardholders do not instantly lose access to funds in their personal banking accounts once they engage in a transaction, rather customers are billed monthly by their credit card company. Hence, this has allowed depositors to reallocate part of their noninterest-bearing monetary assets towards interest-bearing assets, since theoretically consumers would only need to transfer money from less liquid accounts once per month to pay for their credit card bill.

Consumers could, thus, not only take advantage of the credit card rewards based on their expenditures but could also take advantage of the interest-bearing products (MMDAs and other savings accounts) offered by banks. Combined with innovations in forms of direct payment from nontraditional types of money, ${ }^{10}$ this reallocation of more liquid (M1) to less liquid (M2) type of accounts helps explain why the definition of the U.S. transaction balances has become blurry in recent decades. M1 funds do not represent the total money in circulation anymore since customers may be storing funds being used for daily expenses on M2 deposits. Nonetheless, considering total M2 (which includes M1) does not seem appropriate since not all M2 funds are used for daily transactions as highlighted by literature papers in Table 1.1.

New monetary assets and new payment methods are part of the technological innovations that have altered the incentives towards using different monetary assets for transaction purposes in the United States. This is due to financial innovations being continuous, which translates to continuous changes in the incentives behind the two-sided nature of retail payment systems in the United States over time. This section summarized what and how technological and financial innovations in the

\footnotetext{
${ }^{10}$ An example of non-traditional types of money include MMDAs and home equity lines of credit (HELOC), which have checks and/or debit cards that can be used to make payments.
} 
past five decades have altered the liquidity and acceptability of different monetary instruments leading to changes in the types of monetary assets for daily transactions in the U.S. economy.

\subsection{What's Ahead?}

This survey highlights the need of future research to consider the impact that financial and technological innovations have had on money and its characteristics when evaluating the stability of money velocity in the United States. This is because to properly calculate the velocity of money in an economy, one must properly define total money in circulation being used for transactions.

Furthermore, future research should continue to explore the unclear long-run social welfare consequences of these innovations. For instance, the opportunity to take advantage of these technological innovations tend to be more available to individuals who have a higher level of education attainment and income, are older, and who live in more concentrated areas (Frame and White, 2004; Schuh et al., 2013). One of the reasons for this fact is the existence of minimum restrictions necessary to qualify for certain higher interest-earning deposit accounts, which reduce access of low-income earners to such savings tools. These restrictions include potential annual fees, minimum balance required for the account and/or to open one, limit on number of monthly transactions, overdraft fees, and pre-notice of withdrawal of funds by the depositor, which are specified for each monetary asset of M2 described in Table 1.2.

Humphrey et al. (2001) and Schuh et al. (2013) also warn how this new payment system involving debit and credit cards also induces a regressive transfer from low-income to high-income households. For instance, financial institutions charge sellers fees every time a debit or credit card transaction is performed, which leads retailer to merge such expense "into the overhead component of the prices he[/she] charges" (Humphrey et al., 2001). Given that sellers tend to not price discriminate based on payment method, consumers spending with cash (generally lower-income earners) end up paying more for goods/services, while credit card spenders are cross-subsidized by them through their "rewards" program. 
Since these payment methods do not seem to be going away anytime soon, it is essential that future research continue to evaluate concerns regarding whether these new financial innovations are imposing a regressive transfer of wealth from lower- to higher-income earners. The implications of the asymmetric impact of these banking industry innovations across individuals of different socioeconomic classes are of even greater relevance to less developed countries as highlighted by Demombynes and Thegeya (2012).

\subsection{Conclusion}

The content of this paper addresses the shortcomings of the literature in defining transaction balances for the U.S. economy by surveying and critically evaluating the financial and technological innovations that have caused the components of U.S. transaction balances to not be static over time. The survey contributes to the literature by emphasizing that since these innovations are continuous, so should be the process of defining the composition of U.S. transaction balances. In addition, it highlights the importance of understanding how these innovations impact the liquidity and acceptability of different monetary assets. Furthermore, given that most empirical papers on this topic use data from the 2000s, the relevance of this topic is very likely to grow since future studies that include recent data are expected to find results that further strengthen the implications discussed in this survey.

A policy implication this paper derives, which does not dive into the social welfare consequences discussed in the section above, is the potential benefit of further investing on improving and expanding the frequency of data collection of the Survey of Consumer and Payment Choices, which is conducted by the Federal Reserve Bank of Atlanta. Improvements in data collection would not only improve the ability of regulators and researchers to properly estimate US transaction balances and money velocity, but also allow for a better investigation of short- and long-run social welfare consequences of the financial and regulatory innovations the economy experience. 
Table 1.1: Money Demand Literature Papers

\begin{tabular}{|l|l|}
\hline \multicolumn{1}{|c|}{ Authors: } & Topic Covered: \\
\hline Judd and Scadding (1982) & $\begin{array}{l}\text { Analyzes the episode of "Missing Money" in the 1970s. It also } \\
\text { discusses factors that can shift money demand, which could } \\
\text { have potentially caused money demand to become unstable. }\end{array}$ \\
\hline Leventakis and Brissimis (1991) & $\begin{array}{l}\text { Discusses "Missing Money" and "The Great Velocity Decline" } \\
\text { episodes of the 1970s and 1980s, respectively. It extends } \\
\text { Judd and Scadding (1982) by including a larger data set and } \\
\text { for considering international factors that can shift money demand } \\
\text { and could have contributed to the money demand instability } \\
\text { empirical findings. }\end{array}$ \\
\hline Barnett et al. (1992) & $\begin{array}{l}\text { Surveys the importance of the use of nonlinear economic theory } \\
\text { in modeling the demand for money. The paper also focuses "on } \\
\text { highlighting that the simple-sum index should be abandoned both } \\
\text { as a source of research data and as an intermediate target or } \\
\text { indicator for monetary policy." }\end{array}$ \\
\hline Arestis and Mihailov (2011) & $\begin{array}{l}\text { Reviews the entire modern money demand era. }{ }^{a} \text { They provide a } \\
\text { structured classification of different field of studies of Monetary } \\
\text { Economics and qualifying money demand studies as monetary } \\
\text { theory. The classification of these sub-fields is based on the main } \\
\text { issues of inquiry and key techniques used. }\end{array}$ \\
\hline Lagos et al. (2017) & $\begin{array}{l}\text { Investigates the foundation of both classical and quantity theories } \\
\text { of money. This research mainly focusses on pre-modern era studies } \\
\text { and differences between Cantillon's and Hume's views on monetary } \\
\text { theory and policy. Cantillon is referred to as one of the originators } \\
\text { of the classical view, while Hume is argued to originate the quantity } \\
\text { theory view. }\end{array}$ \\
\hline $\begin{array}{l}\text { The survey of the post-modern era which defines liquidity and its } \\
\text { importance. It does not focus its discussion on money demand } \\
\text { stability; rather, they survey how to explicitly model liquidity into } \\
\text { the exchange process of different economic agents. }\end{array}$ \\
\hline (2014)
\end{tabular}

Note: Knell and Stix (2005) also belong to this group. Nonetheless, this research paper does not focus on the critically analyzing their findings.

${ }^{a}$ In this case, the modern era refers to the time range from the post Great Depression period to the end of the 20th century.

${ }^{b}$ Other general classifications are called Monetary Policy and Public Finance. 
Table 1.2: Types of Money in the United States

\begin{tabular}{|c|c|c|c|}
\hline $\begin{array}{l}\text { Types } \\
\text { of money }\end{array}$ & $\begin{array}{l}\text { Traditional } \\
\text { monetary } \\
\text { base }\end{array}$ & $\begin{array}{l}\text { Restrictions that make it } \\
\text { less comparable to cash }\end{array}$ & $\begin{array}{l}\text { What changed over these } \\
\text { past } 50 \text { years? }\end{array}$ \\
\hline Cash & M1 & NA & $\begin{array}{l}\text { Has been less used due to } \\
\text { emergence of new payment } \\
\text { methods and financial } \\
\text { innovations which allowed } \\
\text { individuals to better store } \\
\text { the value of their wealth } \\
\text { over time. It still } \\
\text { represents most of the } \\
\text { U.S. customer payments. }\end{array}$ \\
\hline $\begin{array}{l}\text { Checking } \\
\text { Accounts }\end{array}$ & M1 & $\begin{array}{l}\text { As other types of US sovereign electronic } \\
\text { monies, these funds do not allow for } \\
\text { consumer privacy. However, they provide } \\
\text { higher security of funds due to the FDIC } \\
\text { deposit insurance program. Since } 2011 \text {, } \\
\text { some of these accounts started to offer } \\
\text { positive returns, but they may require } \\
\text { cardholder to pay an annual fee. }\end{array}$ & $\begin{array}{l}\text { Has been less used due to } \\
\text { emergence of new payment } \\
\text { methods and financial } \\
\text { innovations which allowed } \\
\text { individuals to better store } \\
\text { the value of their wealth } \\
\text { over time. It still represents } \\
\text { most of the U.S. customer } \\
\text { payments. }\end{array}$ \\
\hline $\begin{array}{l}\text { Traveler's } \\
\text { Checks }\end{array}$ & M1 & $\begin{array}{l}\text { Safer than cash since it requires a } \\
\text { signature of the consumer upon purchase } \\
\text { of a good/service. }\end{array}$ & $\begin{array}{l}\text { High transaction costs } \\
\text { relative to other monetary } \\
\text { assets. Has not been a very } \\
\text { popular payment method } \\
\text { since the electronification } \\
\text { (technological evolution) } \\
\text { of the banking industry. }\end{array}$ \\
\hline NOW Accounts & M1 & $\begin{array}{l}\text { NOW accounts stands for "negotiable } \\
\text { order of withdrawal." They do not limit } \\
\text { account holders on the number of } \\
\text { transactions and transfers of funds per } \\
\text { month. These accounts are interest- } \\
\text { bearing assets with lower returns than } \\
\text { savings accounts and MMDAs. But, } \\
\text { they do impose restrictions on the } \\
\text { account minimum balance required } \\
\text { and can potentially require a minimum } \\
\text { deposit to open the account. }\end{array}$ & $\begin{array}{l}\text { The emergence of mobile } \\
\text { banking and the higher } \\
\text { usage of credit cards } \\
\text { as payment methods } \\
\text { increased the ability of } \\
\text { individuals to allocate } \\
\text { share of their transaction } \\
\text { (very liquid) deposits } \\
\text { towards interest-bearing } \\
\text { less liquids types of } \\
\text { money such as NOW } \\
\text { accounts. }\end{array}$ \\
\hline
\end{tabular}


Table 1.2 (Cont.): Types of Money in the United States

\begin{tabular}{|c|c|c|c|}
\hline $\begin{array}{l}\text { Types } \\
\text { of money }\end{array}$ & $\begin{array}{l}\text { Traditional } \\
\text { monetary } \\
\text { base }\end{array}$ & $\begin{array}{l}\text { Restrictions that make it } \\
\text { less comparable to cash }\end{array}$ & $\begin{array}{l}\text { What changed over these } \\
\text { past } 50 \text { years? }\end{array}$ \\
\hline ATS & M1 & $\begin{array}{l}\text { Competitive with NOW accounts. } \\
\text { It has lost market to NOW accounts. }\end{array}$ & $\begin{array}{l}\text { The emergence of mobile } \\
\text { banking and the higher } \\
\text { usage of credit cards as } \\
\text { payment methods increased } \\
\text { the ability of individuals to } \\
\text { allocate share of their } \\
\text { transaction (very liquid) } \\
\text { deposits towards interest- } \\
\text { bearing less liquids } \\
\text { types of money such } \\
\text { as ATS accounts. }\end{array}$ \\
\hline $\begin{array}{l}\text { Savings } \\
\text { Accounts }\end{array}$ & M2 & $\begin{array}{l}\text { Traditionally, they offer lower returns } \\
\text { than both MMDAs and NOW accounts. } \\
\text { This type of accounts does not always } \\
\text { require a minimum balance, but when } \\
\text { it does, it tends to be low (usually less } \\
\text { than } \$ 500 \text { ). Savings accounts are very } \\
\text { heterogeneous. Some banks also offer } \\
\text { special high-yield savings accounts, } \\
\text { but these accounts generally include a } \\
\text { high minimum deposit (thousands of } \\
\text { dollars) and higher minimum balance } \\
\text { requirements than even MMDAs. }\end{array}$ & $\begin{array}{l}\text { The emergence of mobile } \\
\text { banking and the higher } \\
\text { usage of credit cards as } \\
\text { payment methods } \\
\text { increased the ability of } \\
\text { individuals to allocate } \\
\text { share of their transaction } \\
\text { (very liquid) deposits } \\
\text { towards interest-bearing } \\
\text { less liquids types of } \\
\text { money such as savings } \\
\text { accounts. }\end{array}$ \\
\hline MMDAs & M2 & $\begin{array}{l}\text { MMDAs can offer relatively high } \\
\text { interest rates since banks can } \\
\text { invest these funds in certificates of } \\
\text { deposit (CDs), government securities } \\
\text { and commercial paper, which low- } \\
\text { yield savings and NOW accounts } \\
\text { cannot do. However, they impose } \\
\text { higher restrictions related to a } \\
\text { minimum balance required in } \\
\text { the account. Federal Reserve } \\
\text { Regulation D limits MMDA account } \\
\text { holders to six monthly transfers } \\
\text { and/or electronic payments out of } \\
\text { the funds of their accounts. }\end{array}$ & $\begin{array}{l}\text { The emergence of mobile } \\
\text { banking and the higher } \\
\text { usage of credit cards as } \\
\text { payment methods } \\
\text { increased the ability of } \\
\text { individuals to allocate } \\
\text { share of their transaction } \\
\text { (very liquid) deposits } \\
\text { towards interest-bearing } \\
\text { less liquids types of } \\
\text { money such as MMDAs. }\end{array}$ \\
\hline $\begin{array}{l}\text { Cryptocurrencies } \\
\text { and other } \\
\text { private monies }\end{array}$ & $\begin{array}{l}\text { Not } \\
\text { included }\end{array}$ & $\begin{array}{l}\text { Not commonly accepted by sellers. } \\
\text { Not issued by the Federal Reserve, }\end{array}$ & $\begin{array}{l}\text { Mobile banking, lack of } \\
\text { stability of sovereign } \\
\text { currencies, and lack of } \\
\text { trust in central banks } \\
\text { around the world have } \\
\text { incentivized the development } \\
\text { of these private types of } \\
\text { money. }\end{array}$ \\
\hline
\end{tabular}




\section{Chapter 2}

\section{How Are West Virginia Banks Different?}

\section{Co-authored with Scott Schuh.}

\subsection{Introduction}

Even before the 2016 presidential election, the economic challenges facing Appalachia, and specifically West Virginia, during recent decades were well known (McCarthy, 2014; Stephens et al., 2013). Table 2.1 illustrates some the challenges by comparing summary statistics for West Virginia (WV) and the United States (US). In 2017, West Virginia's population ranked 39th in the nation at 1.8 million ( 0.5 percent of total population), was shrinking ( -2.0 versus 3.2 percent for five years), and had a relatively high proportion of residents ages 65 and older. Real per-capita income in West Virginia was $\$ 41,600,16$ percent lower than the rest of the nation, and the median WV home price $(\$ 112,000)$-a key part of household wealth—was 42 percent below other U.S. homes. The unemployment rate (5.2 percent) was one full percentage point above other states, and the labor-force participation rate was 53.3 percent- 10.5 percentage points below the rest of the nation. Nevertheless, WV boasted an 11 percentage point higher rate of home ownership at 75.1 percent. ${ }^{1}$

Recognition of economic malaise in West Virginia and Appalchia is widely document from

\footnotetext{
${ }^{1}$ The qualitative nature of this WV-US economic comparison is essentially the same for several years before and after 2017.
} 
newspaper headlines (Badger, 2021) to scholarly research (Isserman and Rephann, 1995; Lewis and Billings, 1997; Herath et al., 2013; Appalachian Regional Commission, 2015). There are many diverse and important factors contributing to weak economic growth. Stephens and Deskins (2018) and Stephens and Partridge (2011), for instance, report, respectively, that the labor force participation and entrepreneurship activity are factors that can partially explain the relatively poor economic performance of WV and the Appalachian region. Other concerns cited are the decline in coal mining, high rates of disability in the workforce, poor education, and opiod or other drug addictions. However, little research has examined the role of financial markets in the economic growth of this area.

This paper investigates whether the nature of state-level banking, the most basic element of financial services, might help explain economic outcomes in the Appalachian region. As a first step, we ask and answer the question: how are WV banks different from those in the rest of the United States? Although banking challenges are unlikely to be responsible for all or most of the poor economic performance of the region, there are good reasons to suspect that banking is an important factor in economic growth (see Danisewicz et al. (2018), Zingales (2015), Berger and Black (2020), Berger et al. (2020), Brown et al. (2019), Khan and Ozel (2016), Nguyen (2019), Berger and Sedunov (2017), among others). Thus, differences between WV banks and those in regions with stronger economic growth may reveal areas where WV banks might be able to adopt reforms and innovations that would increase the contribution of the banking sector to economic growth.

Our research strategy is three-fold. First, we define and classify WV banks and their market, comparing and contrasting them with other banks and markets. Second, we use financial statements to measure and characterize differences in the business strategies of individual banks in WV versus the rest of the nation. Third, we use regression analysis to control for observable characteristics of banks and states and test whether differences in the composition of bank types across states can explain the differences in business strategies of WV and other states' banks. In all of these analyses, we use standard bank-level data from the Reports of Condition and Income, or Call 
Reports (CR), and Summary of Deposits (SOD) for 2017 to focus on cross-section differences, leaving time series analysis for future research.

We find that the WV banking market is broadly similar to that in other states except for the number and size of banks (and branches). In all states, the number of banks has been declining and the average size of banks increasing due to the emergence of interstate banking and technological advances that encourage economies of scale and favor mergers and acquisitions, consolidation, and reduced reliances on branches. In West Virginia, this trend has been similar to, but faster than, the rest of the nation. Also, WV has more and smaller banks (and branches) per capita, which may reflect production or cost inefficiencies. However, the WV banking market does not appear to exhibit materially less competition than the rest of the nation.

We also construct financial statements for banks and find that WV banks exhibit interesting differences in their business strategies from other U.S. banks. In terms of sources of funds, WV banks have a different mix of interest expenses stemming from differences in bank account holdings (liabilities). Interest expenses for WV banks are higher for transaction accounts and for time deposits, but lower for savings accounts, especially money market deposit accounts with higher returns (and risk). In terms of uses of funds, WV bank managers hold notably less diversified and lower risk portfolios of assets. Specifically, WV banks hold 56 percent of their assets in real estate loans, roughly twice as much as other U.S. banks. Naturally, this strategy leads to a greater flow of income from real estate interest. WV banks also generate different proportions of non-interest income: the sale of assets accounts for three times as much income ( 24 percent), with lower proportions in most other categories. A bank's revenue composition deserves attention since it has been shown to be important in predicting bank failures (Berger et al. (2016), Williams (2016)). Together, these findings suggest that characteristics such as risk aversion could differentiate WV banks.

Our regression analysis examines the extent to which heterogeneity in individual bank characterstics and state-level economic variables can explain observed differences in the financial behavior of banks across states. In a standard estimated fixed-effects model, differences between 
WV and other U.S. banks remain statistically and economically significant despite controls for bank heterogeneity. We then broaden the analysis to include individual effects for all states and estimate a two-level mixed-effects model of real estate loans with state-level real GDP per capita and population growth. Although state-level variables improve model fit, neither they nor the bank characteristics can explain the broad heterogeneity in real estate loan shares of banks across states.

The results reveal that financial intermediation differs regionally not because states have different types of banks but because states have banks that make different economic and financial decisions from those in other states. Explaining why banks in one state might hold a much higher share of real estate loans in its asset portfolio than banks in another state is beyond the scope of this paper. To explain cross-state difference in financial intermediation it will be necessary to build and estimate profit-maximizing models of financial intermediation. Based on the evidence reported here, those models need to capture investment decisions that lead to heteroegeneous asset portfolios and competition for deposits that leads to heterogeneous sources of funds.

\subsection{Literature Review}

This study adds to the the strain of literature which studies geographic components of the U.S. banking industry. Most research papers in this literature have focused on studying the geography of the banking industry and on how distance to lenders have impacted the behavior of banks over time. These changes in geographical components are a product of a combination of technological advancements, deregulation, and consolidation of the U.S. banking industry. Alessandrini et al. (2009) presents a great summary of the literature on this topic. Moreover, Radecki (1998) deserves special attention since it studies what is the best geographic measurement that in general can define a bank's market. He defines state borders to be the best approximation to "the true marketplace for banking services." Nguyen (2019) reports a localized and persistent negative effect on small business loan originations from local bank branch closures, which highlights the importance of proximity and market composition. Other studies such as Goetz et al. (2016) focus on the geo- 
graphic expansions of bank holding companies. Nonetheless, our study fits in a smaller niche of this literature, which has a lot of room to grow.

This research focuses on how banks in different geographic regions might differ from banks in other regions, more specifically West Virginia. Investigating differences across regional banking industries can help us better understand the real impact of the banking industry across different regions in the US. The closest study to ours is from Barth et al. (2016) who compare and contrast banks in Alabama. Other studies such as Tokle and Tokle (2000) and Hannan (1979) focuses on studying the competition in the banking industries of Idaho and Montana, and Pennsylvania, respectively. However, only Barth et al. (2016) compare the studied regional banking industry to the remaining of the US.

Barth et al. (2016) also focus on a state, Alabama, which has faced slower economic growth relative to other states. They find that the Alabama banks' returns (ROA) are lower than most U.S. banks, ranked 40th in 2015. In addition, their study explored the impact of the regional banking industry on the real regional economy through a county-level correlation analysis. The study finds that the higher bank loans in a country, higher the county income. In addition, a positive correlation is found between county average weekly wages and both county bank loans and county bank salaries. Overall, their paper support the idea that "banks play an important role in promoting economic growth and development of counties throughout the state" (Barth et al., 2016). Our paper extend their econometric approach including econometric regression methods. Moreover, we also take a first step in trying to identify whether characteristics of a regional banking industry can be explained by observable bank characteristics and whether these are driven by the socioeconomic characteristics of the market these banks operate in.

\subsection{Data}

To investigate our research question, we obtained micro data on all banks in the United States that are insured by the FDIC. This sample constitutes a large part of the U.S. retail banking market but 
does not include credit unions, which are regulated by the NCUA. We also collected data on the socioeconomic characteristics of each state.

The data on depository institutions comes from three main sources: the Summary of Depository Institutions (SDI), the regulatory Call Reports Data (CRD), and the Summary of Deposits (SOD). All these datasets are provided by the the FDIC and based on financial reports filled by banks on a quarterly basis and by its branches on a yearly basis. The financial data available include both the income statement and the balance sheet information of each bank. The data also include geographical location of the branches of each bank.

State regional characteristics come from three sources: the U.S. Bureau of Economic Analysis, the Bureau of Labor Statistics, and the U.S. Census Bureau.

We focus on comparing the characteristics of WV banks with other U.S. banks; the label "US" will refer to the entire United States and US* to the United States excluding West Virginia. In this draft of the paper, we use data for 2017 , for which the latest data were available when the project began. Our strategy is to gain a firm understanding of the answer to our research question for the recent cross-section of banks first. Then we willl examine the dynamics of these differences over time in later versions of this paper or in subsequent research.

\subsection{Banks and Their Markets}

This section describes the types of banks studied and the markets in which they operate. It begins with an initial assessment of the number and size of banks overall and then defines bank types and markets. We provide a basic assessment of the composition and concentration in banking in each market, but not a formal analysis of competition among banks in those markets. ${ }^{2}$

\footnotetext{
${ }^{2}$ Competitive analysis of banking markets is complex and beyond the scope of this initial inquiry, hence deferred for future research.
} 


\subsubsection{Banks}

The U.S. banking industry has been undergoing a comprehensive restructuring, as shown in Figure 2.1. Since the 1980s, the number of banks headquartered in the United States and West Virginia has been declining steadily and rapidly primarily due to consolidation-mergers and acquisitions stemming from the relaxation of regulations against interstate banking-and to technological changes (Aguirregabiria et al. (2016) and Alessandrini et al. (2009), respectively). Although the process of consolidation among banks in West Virginia has been qualitatively similar to the United States overall, consolidation has been greater and faster in West Virginia (larger vertical change in the log scale).

Despite experiencing greater relative banking consolidation, West Virginia still has more and smaller banks than the rest of the nation, as shown in Figure 2.2, which plots the number of banks per capita in West Virginia versus other states (US* = U.S. less WV) by type of charter (federal and state). Remarkably, West Virginia has nearly twice as many banks as other states (32 versus 18 per one million residents). However, the number of banks in operation may be related to the average size of individual banks, so Figure 2.3 plots the distributions of WV and US* bank branches by the size of their banks' total assets. ${ }^{3}$ Nearly four out of five WV branches belongs to a relatively small bank ( $\$ 10$ billion or less in assets), compared with fewer than half in other states.

Striking differences in the rate of consolidation, and in the number and size of WV banks, raise questions about the ability of WV banks to provide services efficiently and profitably. Of course, it is possible that WV residents and businesses have fundamentally different demands for banking services that require more and small banks and branches for some reason(s). If not, however, digging deeper into the composition, behavior, and performance of WV banks may reveal explanations for these differences.

\footnotetext{
${ }^{3}$ The switch from banks in Figure 2.2 to branches in Figure 2.3 is innocuous and for expositional convenience. The distributions of banks by asset size are qualitatively similar to branches but difficult to depict graphically because there are so few very large banks, even in the entire United States. The number of branches in a bank is positively correlated with bank size.
} 


\subsubsection{Definitions}

Not all banks are alike, of course. In addition to characteristics that distinguish all types of firms, such as age and size, banks exhibit other differences related to the nature of financial intermediation. One simple answer to this paper's research question is that the composition of heterogenous banks varies across geographic regions such as West Virginia. However, that answer begs another potentially important question: why does a geographic region have different types of banks? To ensure proper comparison of WV banks with those in other states, it is necessary to define bank types and their markets.

A "bank" is defined as a depository institutions classified as either a commercial bank or saving institutions (savings banks and savings associations). ${ }^{4}$ FDIC-insured branches of foreign banks are dropped for simplicity and lack of consolidated data on their foreign banks. Banks also may be classified by three other characteristics: 1) charter (federal or state); 2) primary regulator (FDIC, Federal Reserve, or OCC); and 3) Federal Reserve membership (national member, state member, or non-member). The FDIC combines these three characteristics into a single "bank class" variable (BKCLASS) in the SOD database.

The market in which a bank operates is more challenging to define for at least two reasons. First, since the passage of Riegle-Neal Act of 1994 allowed interstate banking, the ability to use geographic boundaries to define banking markets has become more diverse and complex. Second, the emergence of technology that enables online banking and the potential for branchless banking (Alessandrini et al., 2009), which causes the definition of markets to become even more complex. This technological change has made it possible for virtually any bank to attract customers from across the nation instead of relying only on customers in their geographic location.

In this paper, a "banking market" is defined as a state as advocated by Radecki (1998). Before interstate banking, state boundaries were a sensible definition, although banks in large states may

\footnotetext{
${ }^{4}$ Credit unions are depository institutions that offer similar services. However, we exclude them from the present analysis because of their different profit status (non-profit instead of for-profit) and the additional work needed to acquire their data come from a separate source and integrate them with the banking data described in Section 2.3 . Given the differences in banks across states reported in this paper, it would be interesting to include credit unions in future research.
} 
not have operated in all cities or counties of the state. Now, however, a bank that operates branches in multiple states may have a diverse presence across states, some of which may not even be geographically contiguous. And banks may locate their headquarters in a state due to tax policies or other factors rather than primarily due to banking conditions in that state. Nevertheless, state borders still reflect important differences in population density, state banking regulations, business practices, and household behaviors that pertain to general economic differences across states. Where feasible and sensible, we conduct some analyses that takes into account the geographic composition of multi-state banks at the county level using information on branches from the SOD database.

Combining the bank and market concepts, we define "WV banks" as those headquartered in West Virginia. Banks headquartered in other states comprise other U.S. (US*) banks. Banks that operate branches only in one state are called single-market banks (SMB), while banks that operate branches in multiple states are called multi-market banks (MMB). ${ }^{5}$ The latter type is further divided into two groups based on total market size by number of states (markets): small MMBs operate branches in fewer than five states, and large MMBs operate branches in five or more states.

\subsubsection{Market Composition}

Figure 2.4 illustrates the composition of banks using a WV map and definitions from the previous subsection. In 2017, there were 5,777 total U.S. banks. Only 57 banks were headquartered in West Virginia, of which 40 were SMBs and 17 were small MMBs compared with 5,044 and 582 US* banks, respectively, that do not have any branches in West Virginia. Thus, among these relatively comparable market categories, West Virginia has a notably lower percentage of SMBs (70 percent versus 90 percent). Another 94 banks are primarily large US* MMBs divided into two categories: 17 that operate branches in West Virginia and 77 that do not; US* banks operating in West Virginia

\footnotetext{
${ }^{5}$ This classification is similar to the one used by Park and Pennacchi (2008). An alternative classification is based on the definition of community banking found in FDIC (2012) and used by Minuci (2021) However, some community banks operate in multiple states and thus this classification does not allow mutually exclusive definitions of geographic markets.
} 
are roughly evenly divided into small and large MMBs. ${ }^{6}$ This grouping enables comparison of all banks operating in West Viriginia (74) distinguished by whether they are headquartered inside (57) or outside (17) the state that may reveal the effects of geography-specific management strategies.

Despite popular perception, West Virginia does not appear to lack access to modern national banking and financial markets. One measure of access to national banking markets is the state share of deposits in SMBs depicted in Figure 2.5. States with relatively high shares of SMB deposits may reflect a lack of adequate access to national banking services. However, the share of SMB deposits in West Virginia actually is relatively low so WV bank customers have a relatively large share of their deposits in banks that operate in regional or national banking markets.

Alternatively, the relatively low share of SMB deposits could signal a disproportionate influence of large national MMBs in the state banking market. Among the nation's four very largest commercial banks, only JPMorgan Chase has branches operating in West Virginia and its WV deposits only accounted for 6 percent of the state total. ${ }^{7}$ One simple measure of competition in banking markets is the share of a state's deposits held by its largest banks. The top four banks operating in West Virginia held 44.5 percent of state deposits in 2017 compared with 36.1 percent for the top four banks in the United States. Thus, the WV banking market exhibits somewhat more concentration than the U.S. national banking market. ${ }^{8}$ For more details, see the tables of top 10 banks in West Virginia and in the United States by assets and by deposits found in the Appendix.

\footnotetext{
${ }^{6}$ The US* in WV grouping is therefore heterogeneous, containing some banks that belong in either the US* small MMBs or large MMBs categories. The latter is heavily influenced by the largest bank operating in West Virginia, JP Morgan Chase.

${ }^{7}$ The other three banks are Bank of America, Wells Fargo, and Citibank. All four megabanks have more than $\$ 1.4$ trillion in assets, with Chase the largest at \$2.2 trillion in 2017. The next largest bank operating in West Virginia is the pending merger of BB\&T and SunTrust, which would be only $\$ 418$ billion in combined assets.

${ }^{8} \mathrm{~A}$ more formal measure of concentration is the Herfindahl-Hirschman Index (HHI) applied to state deposit shares. The 4-bank HHI for West Virginia banks is 674.2, slightly higher than the estimate of 400.4 for all U.S. banks. The HHI is a relatively simple measure of competition in a market, which is typically applied to the shares of sales or revenue rather than deposits as in banking. An HHI of less than 1,500 is often considered indicative of a competition market, so by this measure there do not appear to be first-order concerns about market power in banking at the WV state or national level.
} 


\subsection{Aggregate Banking Activity}

This section begins to analyze economic differences across banks at the aggregate U.S. level and at the WV state level in 2017. ${ }^{9}$ The first step is to use the data described in Section 2.3 to construct cross-section estimates of corporate financial statements for banks in 2017. Bank-level financial statements can be aggregated across all banks to the U.S. level, which serves as the benchmark for comparing differences in banking activity across states in the next Section, or across banks within a state. The financial statements are converted from values (\$) to shares (\%) to enable comparisons across banks with enormous differences in assets.

\subsubsection{Empirical Methodology}

Financial statements reflect the outcomes of firms' underlying economic behavior and illustrate differences in business strategies, productive efficiency, customer demand, profitability, and market value. ${ }^{10}$ We report data for banks' two main financial statements. The balance sheet of bank $i=\{1,2, \ldots, N\}$ contains assets, $A_{i}$, and liabilities, $L_{i}$, related by the identity

$$
A_{i}=L_{i}+E_{i}
$$

where $E$ is shareholders' equity or bank capital. The income statement contains revenues, $R_{i}$, and operating expenses (costs), $C_{i}$, related by the identity

$$
R_{i}-C_{i}=Y_{i}
$$

where $Y_{i}$ is the bank's net income (or profits). Each component of the balance sheet $\left(A_{i}, L_{i}\right)$ and income statement $\left(R_{i}, C_{i}\right)$ has $j=\left\{1, \ldots, J^{k}\right\}$ line items, where $k=\{A, L, R, C\}$. Aggregate com-

\footnotetext{
${ }^{9}$ While analyzing difference across time is potentially interesting as well, we focus on the cross-section analysis in this paper first and leave time-series analysis for future research. Our results are qualitatively and quantitatively similar for the years closely surrounding 2017 so the findings are not sensitive to changes over short periods of time.

${ }^{10}$ For more details about financial statements, see the introduction at the U.S. Securities and Exchange Commission: https://www.sec.gov/reportspubs/investor-publications/investorpubsbegfinstmtguidehtm.html.
} 
ponents are the sum over all line items:

$$
A_{i}=\sum_{j=1}^{J^{A}} A_{j i} \quad L_{i}=\sum_{j=1}^{J^{L}} L_{j i} \quad R_{i}=\sum_{j=1}^{J^{R}} R_{j i} \quad C_{i}=\sum_{j=1}^{J^{X}} C_{j i}
$$

Dividing each line item of the financial statements by its component aggregate value yields the percentage-share vectors of interest. For example,

$$
\overrightarrow{A_{i}}=\left[a_{1 i}, a_{2 i}, \ldots, a_{J^{A}, i}\right]
$$

where $a_{i 1}=\left(A_{i 1} / A_{i}\right) \times 100$, and likewise for the other three components. Finally, aggregate assets are obtained by summing across all banks (U.S.) or banks within a state $s=\{1,2, \ldots, 51\}$ (including the District of Columbia):

$$
A=\sum_{i=1}^{N} A_{i} \text { and } A_{s}=\sum_{i \in s} A_{i s}
$$

Asset-share vectors $\vec{A}$ and $\overrightarrow{A_{s}}$ are calculated analogously. Note that the U.S.- and state-level financial statement shares represent the weighted-average of all banks in the nation or state and thus can be interpreted as the average or representative agent share.

\subsubsection{Aggregate Evidence}

Table 2.2 compares financial statements for U.S. and WV banks in 2017. In the balance, about three-quarters of U.S. bank liabilities are customer deposits (76.8 percent), which represent the main source of funds for banks. About three-quarters of deposits are non-transation (56.7 percent), or savings, more than half (30.4 percent) of which are money market deposit accounts (MMDA). Another 11.9 percent of liabilities were in miscellaneous categories and U.S. bank capital was 11.3 percent. On the asset side, loans accounted for the largest use of funds (54.7 percent) by U.S. banks followed by Treasury securities (20.9 percent). About half of loans are real estate (27.4 percent), with commercial and industrial (C\&I) and consumer loans accounting for most of the rest. Cash 
(currency, reserves, and other types of cash) and Other assets each accounted for about 11 percent of assets.

The income statement shows that about two-thirds of U.S. bank revenue (67.2 percent) comes from interest and the other third from non-interest income (32.2 percent). Given U.S. banks' asset portfolio allocation, it is not surprising that the largest component of interest income from real estate loans, but foreign loans also produce substantial interest (18.6 percent). U.S. banks' noninterest income comes from a variety of services, none of which represents a large portion of revenue. In contrast to revenues, U.S. banks' expenses are much more concentrated in non-interest categories, nearly half (41.7 percent) of which go to salaries.

Although the financial statements of WV and U.S. banks are broadly similar, Table 2.2 reveals several statistically and economically significant differences. In terms of liabilities (sources of funds), WV banks have a notably different composition of deposits. Transactions deposits are about 50 percent higher (18.9 versus 12.3 percent) and non-transaction deposits slightly higher (60.2 versus 56.7 percent) mainly because WV banks have no deposits held in foreign offices (0.0 versus 7.8 percent). Perhaps more importantly, customers of WV banks tend to hold nontransaction (saving) deposits much more in time deposits (21.2 percent versus 9.6 percent) than in MMDAs (21.3 percent versus 30.4 percent). This difference suggests that WV bank customers may be more risk averse-MMDA interest rates fluctuate-or rely more heavily on bank accounts for longer term savings than other U.S. bank customers. WV bank capital is about the same as U.S. banks (12.0 versus 11.3 percent).

In terms of assets (uses of funds), WV banks' appear to hold considerably more conservative asset portfolio than other banks. WV banks invest more in loans (69.8 versus 54.7 percent) than other risker assets (securities, repos, and other). Particularly striking is WV banks' much larger holdings of real estate loans (56.2 versus 27.4), which is evident in both residential and non-residential categories. Real estate loans are secured and thus less risky with lower interest rates. In light of the deposit behavior of WV bank customers, this result raises questions about WV bank managers' investment decisions. In particular, do WV bank managers choose relatively 
conservative in asset portfolios because they reflect their customers preferences, or are the WV bank managers simply more risk averse because they mainly come from the same population as their customers? Or is there some other reason?

Another clue about differences in WV banks is evident from the income statement. WV banks earn a much higher proportion of their revenues (78.7 versus 67.2) from interest than non-interest income (19.9 versus 32.2 percent). Interestingly, the difference in revenue composition does not stem from deposit account fees (6.0 versus 4.5 percent) but rather from less intensive activity in more investment activities that go beyond basic banking services: fiduciary activities, trading, investment, servicing, and a host of other activities (for example, see DeYoung et al., 2015). This result raises complementary questions about the practices of WV bank managers. Is there relatively conservative approach to higher risk banking services a reflection of their customers or the managers' own risk aversion? It does not appear that WV banks cost structure explains much of the differences, as the expenses of WV banks is quite similar to those of all U.S. banks.

To summarize thus far, WV banks have a notably different depositor base and rely relatively more on loans, especially real estate. These differences may be revealing insights about how WV banking activity is related real economic growth in the state. Possible explanations may include risk aversion (by customers and bank managers), lower incomes and wealth of WV bank customers, and lower skills or productivity levels of WV bank managers. Whatever the reason(s), WV banks are less profitable, as can be seen from the asset-weighted rate of return on assets (ROA) plotted in Figure 2.6 from 2009-2017 for WV and U.S. banks. The ROA of U.S. banks was higher than WV banks by about .10 percentage points on average since 2012 . Thus, the different financial choices of WV banks appear to have moderate negative consequences for their profitability. Interestingly, however, WV banks fared much better than U.S. banks during the Financial Crisis and Great Recession of 2007-2009. Despite holding about twice as high a share of real estate loans, the ROA of WV banks declined only about .50 percentage points compared to more than 1.25 percentage points for U.S. banks. ${ }^{11}$

\footnotetext{
${ }^{11}$ This striking time series evidence is related to the literature connecting loan portfolios to bank stability, such as Shim (2019) and Tabak et al. (2011). This line of research merits further investigation but is beyond the scope of this
} 


\subsubsection{Evidence by Market}

This subsection provides a deeper look at differences in WV banks by disaggregating the results from the previous subsection into the six markets defined in Section 2.4. This analysis begins with a stricter distinction between WV and U.S. banks. Rather than aggregating across all U.S. banks, which would include WV banks, we define US* banks as all U.S. banks excluding WV banks (i.e., those headquartered in West Virginia). However, because some US* banks operate branches in West Virginia, they can be considered part of the WV banking market and thus should be included in answers to the paper title.

Due to the large amount of numeric results, this subsection provides evidence on bank financial statements by market using graphs rather than tables for faster and easier comprehension. Each figure contains six panels of graphs with two rows:

1. WV banks: a) WV SMBs; b) WV MMBs; and c) US* in WV MMBs

2. US* banks not in WV: a) US* SMBs; b) US* small MMBs; and c) US* large MMBs.

US* MMBs are divided into small and large groups according to the number of markets; small MMBs operate in up to five states, large MMBs in more than five states. The size definition was chosen to approximate the scope of WV MMBs, so comparing two graphs vertically provides a roughly apples-to-apples assessment of WV and US* markets.

\subsubsection{Sources of Funds: Liabilities}

Like the aggregate analysis, the overall structure of liabilities in WV and US* banks is broadly similar across markets, as shown in Figure 2.7. Interest-bearing deposits are by far the largest item (more than half), followed by non-interest-bearing deposits and capital. There is a modest difference across banking markets—interest bearing deposits have the highest share for SMBs and decline as banks increase in size. However, there is little difference between WV and US* banks in this pattern.

paper and thus left for future research. 
Non-transaction (saving) accounts exhibit notably more differences between WV and US* banks and across markets, as highlighted in Figure 2.8. Most striking is that WV SMBs hold far less MMDA deposits (11 percent) than other banks, including other WV banks and even other US* SMBs. Instead, WV SMBs have high amounts of other saving deposits (35 percent, including traditional passbook saving) and time deposits of all maturities, accounts that are safer and lower cost to banks (lower return to bank customers). Interestingly, US* MMBs operating in West Virginia have by far the highest share of MMDA deposits (66 percent). This finding reveals that at least some WV bank customers can obtain higher return deposits from in-person brick-and-morter branches without having to go to online banking. ${ }^{12}$ This result does not appear to stem from large differences in the interest rates offered by WV versus US* banks, as shown in the Appendix.

\subsubsection{Uses of Funds: Assets}

The relative dominance of real estate loans in the aggregate WV asset portfolios exhibits a more nuanced pattern across banking markets, as shown in Figure 2.9. Most notably, US* banks operating in WV hold only 23 percent of assets in real estate loans compared with more than 50 percent for banks headquartered in West Virginia. Further, the asset portfolio of US* banks in WV is similar to the large US* banks not operating in WV. Thus, it appears that banks do not specialize in real estate loans just because they operate in West Virginia; rather managers of banks headquartered in West Virgina decide to specialize in real estate loans for some reason(s). This result also is evident from the higher shares of real estate assets in WV SMBs and MMBs relative to their US* cohorts.

The tendency of smaller banks to specialize in real estate loans is considerably more pronounced in West Virginia (52 versus 31 percent), where as US* SMBS have more consumer and other loans. We notice WV banks seem to have a conservative approach towards its loan activities. For instance, they seem to hold a lower share of riskier (no collateral) loans such as credit cards and business loans, and instead hold more real estate loans.

\footnotetext{
${ }^{12}$ Of course, this conclusion requires data on the customers of banks in West Virginia and further analysis of how types of households choose banking relationships. Future research on the joint customer-bank relationships are likely to enhance understanding of how WV banks are different.
} 


\subsubsection{Revenues: Income}

Not surprisingly, WV and US* banks' revenues shares in each market, shown in Figure 2.10, are similar to their asset portfolio shares in Figure 2.9. Banks headquartered in West Virginia have a higher share of interest income from real estate loans, naturally. As in the aggregate data, WV banks a much lower share of non-interest income, but only banks headquartered in West Virginia. US* banks operating in West Virginia actually have the highest share of non-interest income (43 percent) in any market. Once again, the data indicate that operating in West Virginia is not the reason for differences; rather, managers of banks headquarted in WV choose a different business strategy than managers of banks coming into West Virginia. This result is potentially important because low shares of non-interest income have been shown to indicate higher probability of bank failure (Berger et al. (2016); DeYoung and Torna (2013); and Williams (2016)). The further decomposition of noninterest income is reported in Figure 2.11.

\subsubsection{Costs: Expenses}

Unlike other aspects of the financial statements, the cost structure of WV banks exhibits very little difference from other U.S. banks in any banking market. A figure of components of expenses in the income statement by banking market can be found in the Appendix. Average interest rates paid by WV banks for deposit accounts exhibit two modest differences from US* banks: 1) WV banks tend to offer lower interest on savings accounts; and 2) multi-market banks operating in WV tend to offer on average lower interest on interest-bearing deposit accounts and time deposits. A figure of deposit rates by banking market also can be found in the Appendix.

\subsubsection{Return on Assets}

Turning again to ROA as a summary statistic of the implications of financial differences in WV banks, Figure 2.12 shows important heterogeneity among banking markets. During the expansion (2012-2017), all US* banks had higher ROA than their WV bank counterparts but the difference 
is greater more for banks headquartered in West Virginia. The gap is largest for WV SMBs, which had an average ROA about $1 / 3$ percentage point less than US* SMBs. On the other hand, it is these lower performing banks headquartered in West Virginia that experienced by far the least decline in ROA during 2007-2010. In contrast, US* banks operating in West Virginia, which is dominated by JP Morgan Chase, experienced a similar decline in ROA to other U.S. banks. Notably, even US* SMBs experienced a very large, though milder, decline in ROA unlike WV SMBs.

\subsection{Econometric Models}

Section 2.5 documents potentially interesting and important differences between WV and US* banks in financial activity at aggregate and banking market levels. The evidence in Sections 2.4 and 2.5.1 suggests the reason is that West Virginia has different types of banks. This section reports tests of this hypothesis that composition of bank types explains observed differences between WV and US* banks. The tests are based on estimates of reduced-form, cross-section models of financial shares at the individual bank level that control for exogenous variables defining bank type and regional (state-level) economic activity. If differences remain after the controls, they likely reflect endogenous economic choices and business strategies that will require structural modeling to explain.

\subsubsection{Regression Specifications}

The baseline regression model is specified as follows. Let $y_{j i s}^{k}$ denote the endogenous variable of interest for bank $i=\{1, \ldots, 5777\}$ headquarted in state $s=\{1, \ldots, 51\}$ from the financial statement shares $\left\{\overrightarrow{A_{i s}}, \overrightarrow{L_{i s}}, \overrightarrow{R_{i s}}, \overrightarrow{E_{i s}}\right\}$ as defined in Section 2.5. For each financial share, the fixed-effects model is

$$
y_{j i s}=\alpha_{j s}^{k}+\beta_{j}^{k} X_{i s}+\varepsilon_{j i s}^{k} \forall j \in J^{k} \text { and } k=\{A, L, R, C\}
$$

where $\alpha_{s}^{k}$ is the state fixed effect and $X_{i s}=B A N K_{i s}$ is a vector of bank-specific explanatory variables that include class, ownership structure, government regulator, age, size, and scope of the bank 
as described in the Appendix in Table G.1. Except for size and scope, all explanatory variables are categorical with one category excluded from the regression. All data are at the consolidated bank level and banks are assigned to the state in which it is headquartered.

There are four continuous variables of bank size and scope, which are presumed exogenous for the purpose of time $t$ financial decisions. Two variables represent bank size: 1) log average value of deposits (nominal dollars); and 2) share of total deposits (percentage of U.S. deposits). Because MMBs operate in more than one state, two other variables represent bank scope (market defined by states): 1) share of states in which the bank operates (percentage out of 51); and 2) share of population of the states in which it operates (percentage of national population). Although these explanatory bank variables are endogenously determined in the long run, they can probably be taken by the bank at least as predetermined, and possibly exogenous, in the short run when making endogenous decisions about the asset and liability management.

Because the financial shares sum to 100 , the regression models in equation (2.1) form a system of equations. For example, the system of equations for asset shares is

$$
\begin{aligned}
a_{1 i s} & =\alpha_{1 s}^{A}+\beta_{1}^{A} X_{i s}+\varepsilon_{1 i s}^{A} \\
a_{2 i s} & =\alpha_{2 s}^{A}+\beta_{2}^{A} X_{i s}+\varepsilon_{2 i s}^{A} \\
\vdots & =\vdots \\
a_{J_{i}^{A} s} & =\alpha_{J_{s}^{A}}^{A}+\beta_{J^{A}}^{A} X_{i s}+\varepsilon_{J_{i}^{A} s}^{A}
\end{aligned}
$$

The asset shares, $a_{j i s}$, are linearly dependent. However, the full system can be estimated equationby-equation because the explanatory variables all have the same explanatory variables; see Theil (1971) for more details and Schuh and Stavins (2010) for an example of this econometric approach applied to shares of payments made by consumers using payment instruments.

Although the baseline fixed-effect model can identify state-level differences in financial shares, there is evidence-including Table 2.1—of variation in state-level economic activity that also may contribute to differences in banking behavior across states. Moulton (1990) shows that adding 
macro (aggregate) variables, such as state real GDP, to micro (bank-level) regressions (2.1) induces downward bias in standard errors, which requires an ex post correction to obtain proper estimates of parameter uncertainty. The problem stems from a lack of variation in the macro variables across micro units, which imparts an error to the state fixed effect: $\alpha_{s}=\alpha_{0}+\eta_{s}$, where $\eta$ is a statelevel error that is correlated with $X_{i s}$ and thus violates one of the key Gauss-Markov assumptions underlying the fixed-effects regression (For more detailed info see Hausman and Taylor (1981) and Bafumi and Gelman (2006)).

To address this problem, we use a multi-level mixed-effects model that explicitly specifies the varying intercept in (2.1). ${ }^{13}$ Suppresssing the $j$ and $k$ notation, the random state effect can be written as

$$
\alpha_{s}=\alpha_{0}+\gamma_{z} Z_{s}+\gamma_{x} \bar{X}_{s}+\eta_{s}
$$

where $Z_{s}$ is a vector of state-level economic variables, $\bar{X}_{s}=\sum_{i \in S} X_{i s}$ is a vector of average of bank characteristics within a state, and $\eta_{s}$ is the random error. Equations (2.1) and (2.2) represent the mixed-effects model, which can be combined and written as

$$
y_{i s}=\left[\alpha_{0}+\gamma_{z} Z_{s}+\gamma_{x} \bar{X}_{s}\right]+\beta X_{i s}+\varepsilon_{i s}^{\prime}
$$

where $\varepsilon_{i s}^{\prime}=\left(\varepsilon_{i s}+\eta_{s}\right)$. For properly chosen $Z_{s}$ and $\bar{X}_{s}, E\left[X_{i s} \varepsilon_{i s}^{\prime}\right]=0$ and there is no longer a violation of the Gauss-Markov assumption.

\subsubsection{Estimation}

The baseline fixed-effects model (2.1) is estimated with OLS for each financial share. For comparison with Section 2.5.2, we estimate just two state effects $\left(\alpha_{W V}\right.$ and $\left.\alpha_{U S^{*}}\right)$ to quantify differences in the average financial shares of WV banks after controlling for individual bank characteristics $\left(X_{i s}\right) .{ }^{14}$ The null hypothesis tested is $H_{0}: \alpha_{W V}=\alpha_{U S^{*}}$, a standard coefficient restriction that pro-

\footnotetext{
${ }^{13}$ We thank Marcin Hitzcenko for introducing us to this methodology. See Gelman et al. (2008) for an application to modeling of regional variation in U.S. presidential voting.

${ }^{14}$ This approach was popularized in the international trade literature by Bernard and Jensen (1999).
} 
duces an F-statistic. ${ }^{15}$ Rejection of the null hypothesis indicates that WV banks behave differently than other banks for reasons other than differences in the composition of bank types in the state. The estimated fixed effects will be roughly comparable in magnitude to the empirical estimates in Section 2.5.1 (as they should be) but not exactly the same due to the presence of controls $\left(\beta X_{i s}\right)$. For this reason, the results include estimates of the state fixed effects without the controls.

The multi-level mixed-effects model (2.1) and (2.2) is estimated with maximum likelihood for selected financial shares that exhibit the most economic relevance. ${ }^{16}$ To investigate the potential uniqueness of all states, we estimate the mixed-effects model with 51 separate state random effects. Although the random effects (2.2) are not estimated directly, we capture their best linear unbiased predictions (BLUP), $\hat{\alpha}_{s}$, for further analysis. Absent a structural model, it is difficult to form strong prior beliefs about the most suitable state-level variables, $Z_{s}$. After some exploration, we settled on two common measures of aggregate economic activity: 1) log of real state income per capita; and 2) five-year population growth rate. ${ }^{17}$ Options for $\bar{X}_{S}$ variables are limited by the fact that most are dummy variables, hence only the continuous variables are eligible (three measures of bank and market size plus the log average branch deposit value).

Both econometric models make two simplifying assumptions. First, despite the evidence of variation across banking market in Section 2.5.3, the regression coefficients do not vary between SMBs and MMBs. In part, this assumption is necessary because the total number of banks headquartered in West Virginia is small (57), so further disaggregation would reduce precision. Second, we assume that the effects of observable bank characteristics on financial activity $(\beta)$ are the same for all banks regardless of geography and thus estimate only random-intercept models, not randomslope models. For example, this restriction assumes bank size is correlated with financial shares similarly for WV and all US* banks. This assumption seems like a reasonable starting point absent an obvious economic reason to expect otherwise, but may be worth exploring in future research.

Details of the regression data and sample are as follows. All data used in estimation are for

\footnotetext{
${ }^{15}$ Although the regressions are weighted by bank size, we still use the "white.adjust" option of the linearHypothesis command in $\mathrm{R}$ for a heteroskedasticity-robust F-test.

${ }^{16}$ This model can be estimated with the R command lmer or the STATA command xtmixed.

${ }^{17}$ Alternative random effects explored are listed in the $Z$ Variables section in the Appendix in Table G.1.
} 
2017:Q2. Regressions are weighted by banks' shares of total U.S. bank assets except for the regression components of real estate loans, which are weighted by a bank's share of total U.S. real estate loans. Each regression uses the full sample of U.S. banks described in Section 2.3. Controls for bank size and market size are defined by the state in which a bank is headquartered. While this definition is fine for SMBs, the market for a large MMB operating in many states is much larger than the state in which it is headquartered. In fact, the state in which an MMB is headquartered may have been chosen for certain purposes such as favorable tax treatments and may be very differerent from the other states in which the MMB operates. Thus, for robustness, we also estimated the econometric models with a subsample of only SMBs to identify potential influences stemming from multi-market banking. The results were qualitatively and quantitatively similar to the full sample estimates. ${ }^{18}$

\subsection{Results}

This section reports the results of estimating the econometric models in Section 2.6. For each model, the dependent variables are financial statement shares measured in percent.

\subsubsection{Fixed-effects Models}

Estimation results for the fixed-effects models appear in Tables 2.3 through 2.10 , organized by financial statement. Each table reports the fixed-effects coefficients first, followed by the controls. The bottom of each table reports regression diagnostic statistics. For comparison with the data portrayed in the figures of Section 2.5.3, the first two lines report fixed-effect estimates from separate regressions that exclude the controls. The statistic labeled "F.E. (fixed-effects) contribution" is the ratio of adjusted $R^{2}$ for the regression without controls to that of the full regression. The p-value of the hypothesis test for differences between WV and US* is of central interest; values below .10 indicate likely significant differences in West Virginia banks.

\footnotetext{
${ }^{18}$ Results for estimation with the SMB subsample are available on request.
} 


\subsubsection{Sources of Funds: Liabilities}

After controlling for bank characteristics, WV bank are remarkably similar to other banks except for the distribution of interest-bearing accounts. Table 2.3 shows that only two high-level categories of liabilities—non-interest bearing deposits (slightly lower) and Federal Reserve reverse repos (slightly higher)—are statistically significantly different from US* banks, but both are 2 percentage points or less apart.

Digging deeper into interest-bearing accounts reveals that WV banks exhibit economically significant differences in deposits. Table 2.4 shows statistically significant differences in WV banks' small time deposits, where categories less than $\$ 250,000$ are about 3 percentage points higher each than in US* banks (12.4 versus 8.8 percent and 12.3 versus 9.5 percent, respectively). Although not statistically significant, WV banks' share of money market deposit accounts (MMDA) is almost 11 percentage points lower (24.3 versus 34.8 percent); likewise, WV banks' share of transaction deposits is almost 5 percentage points higher than US* banks. Although statistically weak, these point estimates affirm the earlier observation that WV depositors tend to favor safer deposit accounts with lower returns than other US* depositors for some reason.

\subsubsection{Uses of Funds: Assets}

After controlling for bank characteristics, WV banks' asset portfolios remain notably different from other U.S. banks. Table 2.5 shows that all WV bank loan shares except other consumer loans are statistically significantly different from US* banks' shares. In particular, WV real estate loans are nearly 12 percentage points higher (58.4 versus 46.9 percent) than US*, an economically large differential. In contrast, the WV shares of C\&I, credit card, and other non-consumer loans are all statistically significantly lower than corresponding US* banks' shares. For these loan categories, the controls have important economic effects, especially for C\&I loans where the WV and US* fixed effects dropped from 8.2 and 12 percentage points, respectively, to .5 and 3.6 percentage points. For all non-loan assets, however, WV shares are insignificantly different from other US* banks. 
Digging deeper into real estate loans reveals that WV banks' specialization primarily reflects a heavy emphasis on lending for smaller residential properties. Table 2.6 shows that WV banks have 14 percentage points more (53.2 versus 39.3 percent) real estate loans for 1-4 unit residential properties than US* banks. The bulk of this difference is accounted for by US* banks' greater shares of lending for non-residential, non-farm (i.e., commercial) real estate (33.9 versus 25.5 percent) and agricultural real estate (4.9 versus -0.2 percent). Interestingly, WV banks do not lend significantly less for either contruction development or for larger family units (5+) such as apartment and condominium complexes.

\subsubsection{Revenues: Income}

Controlling for bank characteristics, the sources of income for WV banks is essentially the same as other U.S. banks except for differences in loan interest that largely mirrors the asset-portifolio differences discussed earlier. Table 2.7 shows that WV banks have much higher shares of income from real estate loans (59.7 versus 47.6 percent) and proportionately lower shares of income from business and other loans. This result is a natural and unsurprising consequence of WV banks' relative specialization in real estate assets. More surprising is that large differences in non-interest income between WV and US* banks at the aggregate level (19 and 32 percent, respectively, in Table 2.2) essentially disappear after controlling for bank characteristics (1.7 versus 2.7 percent). Thus, in the case of non-interest income, the composition of WV banks accounts for observed differences; higher WV shares of state member banks, saving associations, and bank holding companies are key contributors.

Digging deeper into non-interest income reveals many components with economically large differences between WV and US* banks but few that are statistically significant. Table 2.8 shows only two significant differences. WV banks' shares are about 3-4 percentage points lower than US* banks for other investment income (5.6 versus 9.2 percent) and service-fee income, including fees on real estate loans (1.7 versus 4.8 percent). Large but statistically insignificant differences in point estimates arise for two categories that account for about half of non-interest income: sales 
of assets and other non-interest income. WV banks have higher shares of asset sales (24.5 versus 7.8 percent) and lower shares other non-interest income (20.7 versus 40.4 percent). Also not statistically significant but economically intriguing are WV banks' greater shares of income from fiduciary activity (10.6 versus 5.0 percent) and deposit account fees (34.9 versus 29.9 percent).

\subsubsection{Costs: Expenses}

After controlling for bank characteristics, the cost structure of WV banks is only moderately different from other US* banks. Table 2.9 shows that interest expenses, which account for less than one-fifth of all banks expenses, are insignificantly different for WV and US* banks but the labor and physical capital components of non-interest expenses are significantly different. WV banks' share of share of salaries and benefits is about 5 percentage points lower than in US* banks (43.7 versus 48.9 percent) and WV banks' share of net physical capital (structures and fixed assets) expenses and other non-interest expenses are higher by a similar proportion, although the latter is not statistically significantly so.

Digging deeper into the relatively smaller component of interest expenses reveals larger and economically significant cost differentials that reflect the patterns of deposit shares discussed earlier. Table 2.10 shows that WV banks have nearly one-third as much interest expenses on savings accounts (11.1 versus 28.3 percent), which include MMDAs, as do US* banks. ${ }^{19}$ On the other hand, WV banks have nearly twice as much interest expenses for transaction accounts (11.0 versus 6.0 percent) and, not surprisingly, about 10 pecentage points more for time deposit accounts (50.3 versus 40.1 percent), although the latter is not statistically significant.

\subsubsection{Summary of Fixed-effects Results}

The main finding from the fixed-effects model estimation is that the composition of bank types does not fully explain economically significant differences in financial behavior between WV and US* banks. Two key differences remain between WV and US* banks. First, WV banks receive deposit

\footnotetext{
${ }^{19}$ In separate calculations not reported here, we find that WV banks do not pay significantly different interest rates on deposits so the difference in interest costs must result from higher average saving account balances in US* banks.
} 
portfolios that rely more heavily on transaction accounts and on less risky non-transation accounts that offer safer, lower returns. Heteregeneity in the customer base of WV banks may play a role in explaining this difference. Second, WV banks also invest in asset portfolios that rely heavily on real estate loans, especially those for small (1-4 unit) residential mortgages. Heterogeneity in the bank managers of WV banks may play a role in explaining this difference. To the extent that WV bank managers are also part of the population of WV bank customers, there may be common factors in the characteristics of the managers and customers. Heterogeneity in the economic profile of West Virginia likely plays a role in explaining differences as well, potentially influencing both deposit and bank management decisions.

\subsubsection{Mixed-effects Models}

This subsection reports results for the mixed-effects mode, narrowing the focus to real estate loan shares because they are the most economically important difference between WV* and US* banks. We do not report estimates for the bank characteristics $(\beta)$ because they are essentially the same as in the fixed-effects models. ${ }^{20}$ Instead, this section analyzes all 51 state effects to expand the scope beyond West Virginia and explore the role of regional economic conditions in bank financial behavior. For comparison, $\hat{\alpha}_{0}$ is 39.1 (1.84 standard error) for the fixed-effects model with 50 states (CO excluded because it is closest to the constant) and 40.1 (2.10) for the mixed-effects model.

The heat map in Figure 2.13 shows no clear regional pattern in the actual data on real estate loan shares by the state of banks' headquarters. Banks in most states west of the Mississippi River have relatively low shares, especially NV, UT, and SD, but there are many exceptions. States in the northwest corner (WA and OR), northern border (MO, ND, and MN), and southwest corner (AR and LA) of that area have high shares. East of the Mississippi River, real estate shares vary widely across states. States with high shares in the Mid-Atlantic (WV, MD, NJ), New England (VT, NH, $\mathrm{ME}$ ), and Southwest (SC, FL) are separated by states with relatively low shares (e.g., MA, VA, and

\footnotetext{
${ }^{20}$ Indeed, the estimated coefficients in the mixed-effects model are typically within one significant digit (integer or one decimal place) of the fixed-effects estimates, as they should be. A full set of regression results for the mixed-effects model is available upon request.
} 
$\mathrm{NC}) .^{21}$

Fitted state-level estimates of real estate loan shares from the mixed-effects model (orange bars) are plotted in Figure 2.13 along with the data (black bars) and states appearing in ascending order. Most states have actual loan shares of roughly 35 to 55 percent but some have much larger or smaller shares. Five states have loan shares greater than 60 percent and four of them are in New England (NJ is the fifth). Eight states have loan shares less than 35 percent with no geographic pattern; the two lowest are less than 15 percent and contiguous (NV and UT) but the other six are spread out.

Figure 2.13 includes two types of fitted values $\left(\hat{y}_{s}\right)$. The top panel contains fitted values using only the intercept and estimated bank characteristics, $\hat{\alpha}_{0}+\hat{\beta} X_{i t}$. These fitted values are essentially flat for all but about three of the relatively low shares (SD, OH, and NC). Thus, bank characteristics alone systematically overpredict low shares and underpredict high shares, although there is a bit more cross-state variation in the fitted values for lower shares than higher shares. This result confirms that variation in the composition of bank types across banks does not explain real estate shares well.

The bottom panel of Figure 2.13 contains fitted values from the full mixed-effects model. Adding random state-effects clearly improves the fit of the full model (relative to bank characteristics only) by generally raising estimates for higher loan shares and lowering them for lower loan shares. Indeed, the cross-state standard deviation of errors for the full model is about 17 percent lower (12.17 versus 10.13) than for the model with bank characteristics only. However, the errors from the full model are still sufficiently large to be economically significant; in fact, some fitted values of the full model make larger errors than the restricted model with bank characteristics only. Thus, the addition of regional variables does not change the basic conclusion that observable characteristics — at the bank or state-level—do not explain variation in real estate loan shares across states.

\footnotetext{
${ }^{21}$ The real estate shares have somewhat different regional patterns when disaggregated by banking market (SMB, MMB small, and MMB large). The difference is most pronounced for SMBs, where some states have few if any of those banks. However, even in that case the correlation of real estate shares between SMBs and all banks (depicted in Figure 2.13) is still .76 and there is still no clear regional pattern.
} 
Model errors $\left(y_{s}-\hat{y}_{s}\right)$ for both the full mixed-effects model and the standard fixed-effects model with 50 state effects are plotted in Figure 2.14 (orange and green, respectively). Two results are particularly striking:

- Average absolute errors are notably smaller (roughly 1 percentage point) for the half of states with loan shares more than about 43 percent. This group includes West Virginia, so WV banks are not especially different when it comes to explaining relatively high shares of real estate loans. However, errors in states with higher loan shares can be 5 percentage points or more, which are economically large and merit further explanation.

- Average absolute errors are considerably larger (roughly 8 percentage points) in states with shares less than 42 percent. Four states (NV, VA, SD, and MA) have absolute errors of more than 20 percentage points and about a half dozen more have errors of 10-20 percentage points. Thus, with respect to real estate loans, the most unusual states are actually those with unusually low shares, not states like West Virginia with high shares. Investigating why some states have banks that hold unusually low real estate shares may be an illuminating path for future research to discover the economic reasons why banks differ across states.

The magnitudes and patterns of these model errors reinforce the important conclusion that observable state and bank characteristics do not explain economically important differences in banks' real estate loan investment decisions. Instead, other factors must be influencing these decisions.

Another important finding from Figure 2.14 is that the two models' errors are quite similar for all states (means and cross-state standard deviations almost numerically identical). Thus, the addition of state-level variables and introduction of random effects depending on real GDP per capita and population growth does not make a significant contribution to the overall fit of loan shares, although the interpretation of the state effects is enhanced somewhat (more below). The modest differences between the model errors can be seen more clearly in Figure 2.16, which contains a scatter plot of the fixed and random state effects contributions (relative to the CO state effect, which was the closest to the intercept). The contributions are highly positively correlated, lying close to 
the 45-degree line. However, the fixed-effects contributions tend to be consistently and increasingly larger than the random effects contributions when both are positive. This result suggests that regional economic variables are explaining part of the data, especially for states with higher shares.

Finally, we can decompose the relative contributions of the two state-level variables to the random effects, as shown in Figure 2.17. Note that unlike previous figures, these contributions are not plotted in ascending order of state loan shares but rather are organized by geographic region. The vertical lines represent the Census Bureau's four regions (solid black) and nine divisions (gray). ${ }^{22}$ Overall, state real GDP per-capita is the most important regional effect explaining banks' real estate shares across states and in most states it is by far the dominant component. The population component is non-trivial in some states but close to zero in many others. Interestingly, the state-level variables tend to make mostly negative contributions to state effects for the West and Midwest regions, and mostly positive contributions in the Northeast and South regions. Exploring alternative state-level economic variables and investigating the role of regional economic factors is an important task for future research.

\subsection{Conclusion}

This paper investigates differences in financial and economic behavior among banks of different states. The original motivation was to ask and answer the question whether West Virginia banks are different from other banks in the United States and investigate whether those differences might be related to differential economic growth in West Virginia. The results suggest that, yes, WV banks are different in two important ways: 1) their customers make significantly different deposit decisions than other banks; and 2) their bank managers make significantly different decisions about asset portfolio allocations, primarily banks headquartered in West Virginia and not banks from outside the state operating in West Virginia. In both cases, then, the residents of West Virginia

\footnotetext{
${ }^{22}$ The states are listed geographically roughly from from left to right and clockwise, with the following order of the nine Census regions: Pacific (\#9, four states); Mountain (\#8, eight); West North Central (\#4, seven); East North Central (\#3, five); Middle Atlantic (\#2, three); New England (\#1, six); South Atlantic (\#5, nine); East South Central (\#6, four); and West South Central (\#7, four).
} 
and the surrounding region likely have different characteristics that drive their deposit and asset management behavior. Investigating this possibility seems like a fruitful direction of research.

Other states also have banks with interesting financial and economic difference as well. This paper only investigates heterogeneity in banks' real estate loan shares across states, but it reports interesting features. West Virginia is not the only state with banks specializing in real estate loans, as some have more than 60 percent of their assets invested (compared to 57 percent in West Virginia). However, the most economically different states have banks with less than half the share of WV banks (25 percent less). These states have banks that specialize in assets different from real estate loans.

We find that differences in banks' financial and economic behavior across states is not well explained by differences in the composition of bank types across states. While there are important differences in bank types across states, those differences do not explain why banks have different depositor and bank manager behaviors. An important implication of this result is the need for more research to model banks' profit maximizing behavior. Strategies to attract certain types of deposits are jointly determined with strategies to invest loanable funds in bank assets. Understanding this optimization problem better is necessary to explain cross-state differences in bank behavior and how they related to real economic growth. Until then, it is premature to draw conclusions about how differences in state banking markets contribute to state economic conditions. 
Table 2.1: 2017 Regional Characteristics: WV vs. US

\begin{tabular}{|lcccc|}
\hline & WV & US & US-WV & WV/US \\
\hline Population (millions) & 1.8 & 366.3 & 364.5 & 0.0050 \\
Population growth (\% 5 years) & -2.0 & 3.2 & 5.2 & \\
Age (share >65, \%) & 18.3 & 15.6 & -2.7 & \\
Real income per capita $(\$ 1,000)$ & 42.0 & 49.0 & 7.0 & 0.86 \\
Unemployment rate $(\%)$ & 5.2 & 4.4 & -0.8 & \\
LF participation rate $(\%)$ & 53.3 & 62.8 & 9.5 & \\
Home ownership rate $(\%)$ & 75.1 & 63.9 & -11.2 & \\
Median existing home price $(\$ 1,000)$ & 112 & 194 & 82 & 0.58 \\
\hline
\end{tabular}


Figure 2.1: Number of Banks

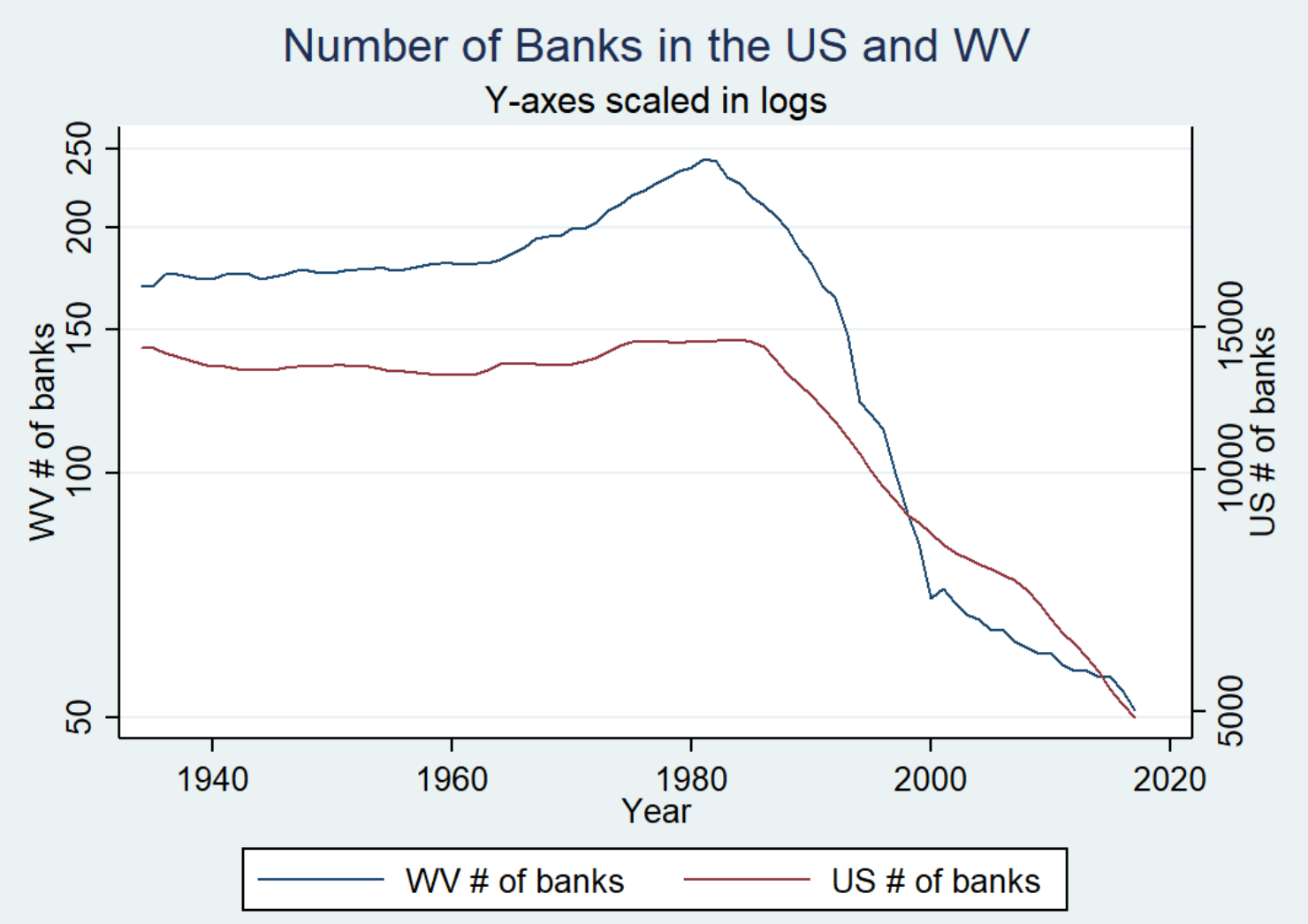


Figure 2.2: Banks per Capita by Charter, 2017

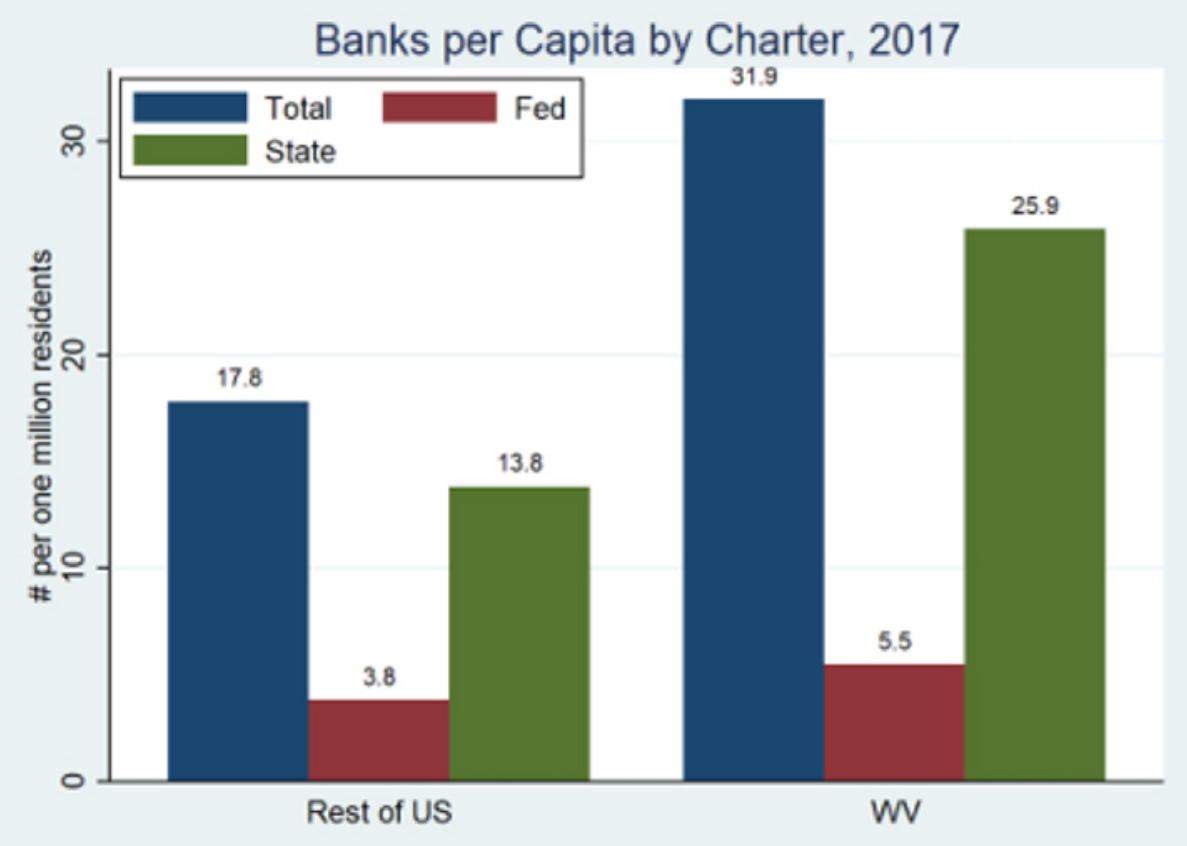


Figure 2.3: Distribution of Branches by Asset Size, 2017

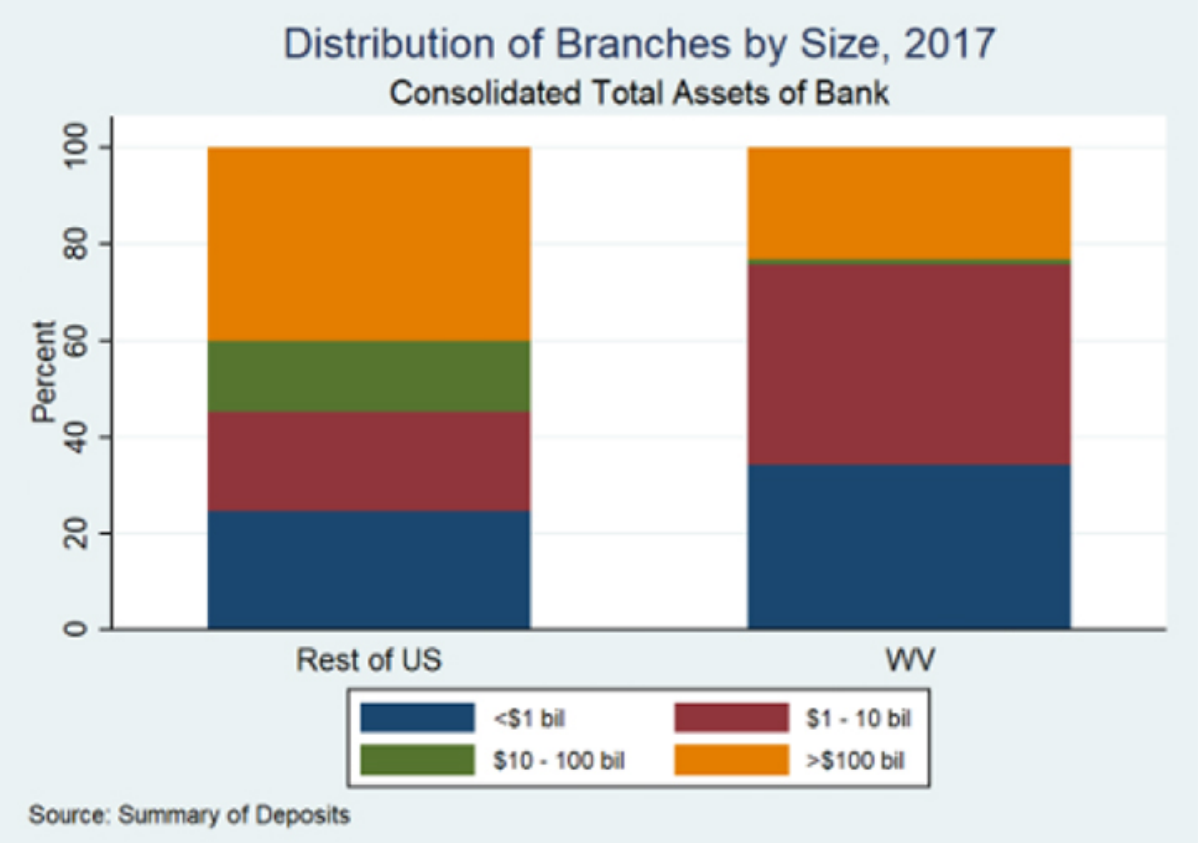


Figure 2.4: Composition of WV Banking Industry, 2017

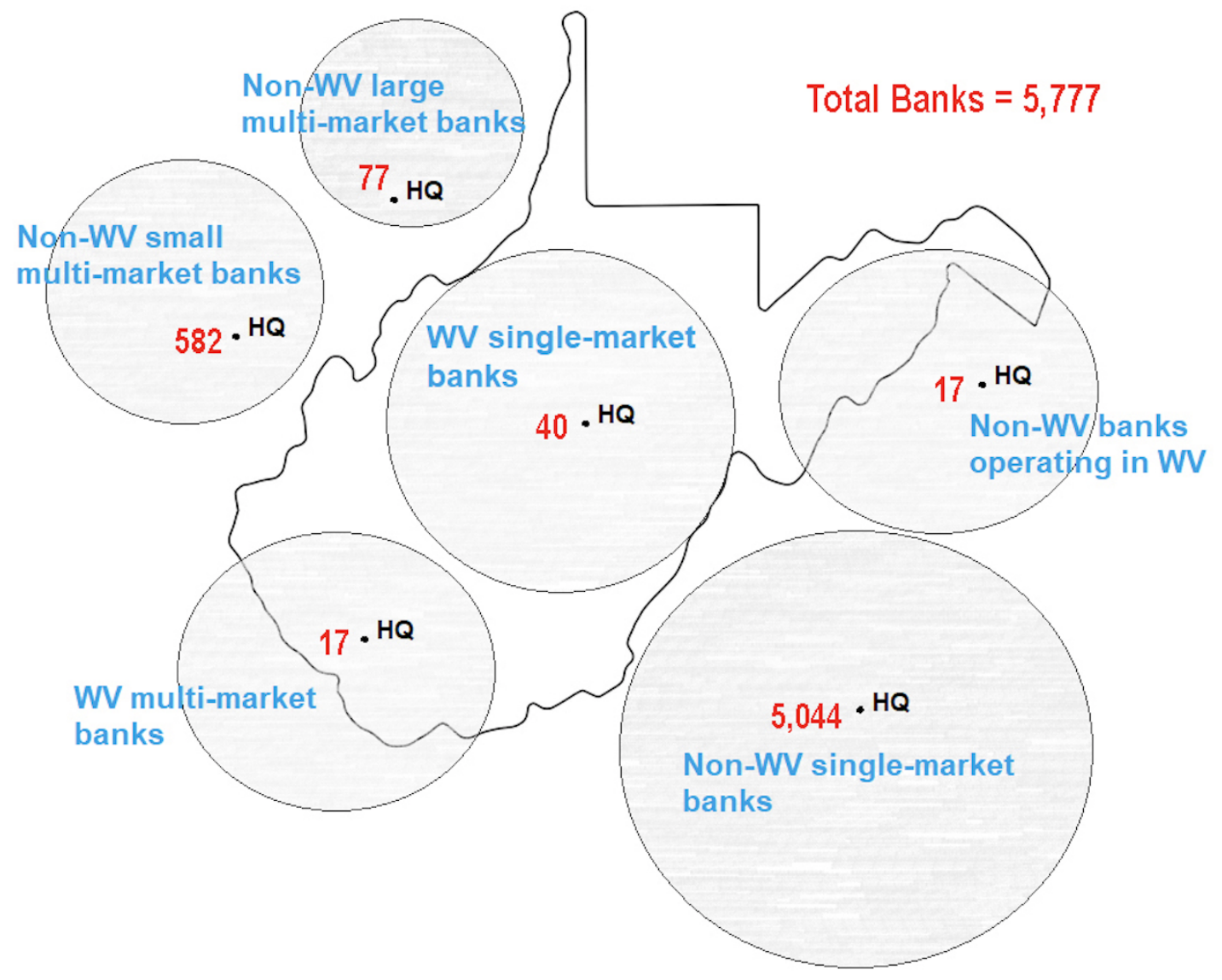


Figure 2.5: SMB Deposit Shares by State, 2017

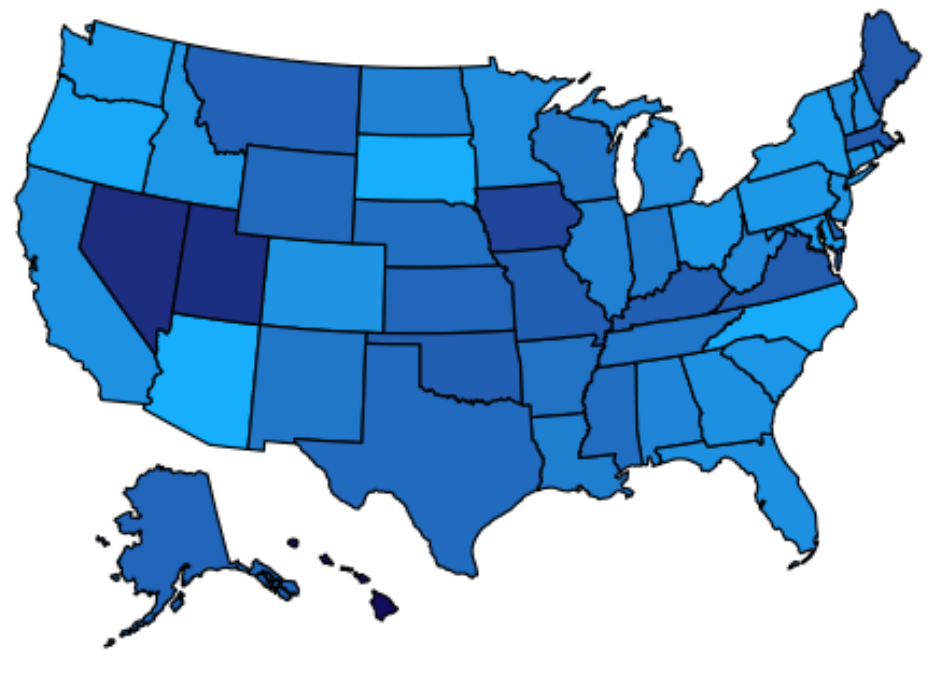

Deposits Share of Single-Market Banks by State (2017)

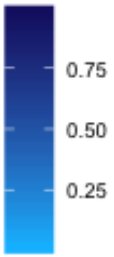


Table 2.2: Financial Statements for U.S. and WV Banks, 2017

BALANCE SHEET

ASSETS

Cash and Balances Due

Currency

Reserves

Other

Securities

Loans

Real estate

Residential

Non-residential

C\&I

Consumer

Credit cards

Other consumer

Other loans

Net of earned income

Allowance for Loan Losses

Repos sold to Fed

Other assets

TOTAL

$\begin{array}{rr}\text { US\% } & \text { WV\% } \\ \mathbf{1 1 . 0} & \mathbf{4 . 3} \\ 0.4 & 0.5 \\ 6.9 & 1.4 \\ 3.6 & 2.5 \\ \mathbf{2 0 . 9} & \mathbf{1 8 . 1} \\ \mathbf{5 4 . 7} & \mathbf{6 9 . 8} \\ 27.4 & 56.2 \\ 16.6 & 31.3 \\ 10.8 & 24.9 \\ 11.6 & 8.2 \\ 9.2 & 4.1 \\ 4.6 & 0.1 \\ 4.6 & 4.0 \\ 7.1 & 2.0 \\ 0.0 & 0.0 \\ 0.7 & 0.7 \\ \mathbf{2 . 4} & \mathbf{0 . 4} \\ \mathbf{1 1 . 1} & \mathbf{7 . 4} \\ \mathbf{1 0 0 . 0} & \mathbf{1 0 0 . 0}\end{array}$

TOTAL

Addenda

Interest-bearing accounts

Non-interest bearing accounts

\begin{tabular}{rrc}
\multicolumn{1}{c}{ US\% } & WV\% & EXPENSES \\
$\mathbf{6 7 . 2}$ & $\mathbf{7 8 . 7}$ & Interest Expense \\
53.0 & 68.0 & Deposit Accounts \\
22.9 & 55.4 & Transaction Accounts \\
8.7 & 8.1 & Nontransaction Accounts \\
16.6 & 4.4 & Saving Accounts \\
4.9 & 0.1 & Time Deposits \\
9.9 & 9.6 & Purchased Fed Repos \\
4.2 & 1.0 & US Treasuries Securities \\
32.2 & 19.9 & Other \\
4.3 & 2.7 & Noninterest Expense \\
4.5 & 6.0 & Salaries \\
3.3 & 0.0 & Assets \\
2.1 & 0.8 & Other \\
1.6 & 0.1 & \\
0.2 & 0.0 & \\
1.9 & 3.0 & \\
14.4 & 7.3 & \\
99.4 & 98.7 & TOTAL
\end{tabular}

$99.4 \quad 98.7$

\begin{tabular}{rr}
\multicolumn{1}{c}{ US\% } & \multicolumn{1}{c}{ WV\% } \\
$\mathbf{7 6 . 8}$ & $\mathbf{7 9 . 2}$ \\
12.3 & 18.9 \\
56.7 & 60.2 \\
30.4 & 21.3 \\
16.6 & 17.7 \\
9.6 & 21.2 \\
6.2 & 18.6 \\
3.4 & 2.7 \\
7.8 & 0.0 \\
$\mathbf{1 . 5}$ & $\mathbf{2 . 9}$ \\
$\mathbf{6 . 4}$ & $\mathbf{5 . 1}$ \\
$\mathbf{4 . 0}$ & $\mathbf{0 . 8}$ \\
& \\
$\mathbf{1 1 . 3}$ & $\mathbf{1 2 . 0}$
\end{tabular}

100.0

100.0

$57.0 \quad 61.1$

$19.7 \quad 18.1$

US\% WV\%

$12.3 \quad 13.6$

$6.7 \quad 10.5$

$0.6 \quad 1.3$

$6.1 \quad 9.2$

$2.8 \quad 2.2$

$3.4 \quad 7.0$

$0.3 \quad 1.0$

$3.6 \quad 1.8$

$1.7 \quad 0.3$

$87.7 \quad 86.4$

$41.7 \quad 43.9$

$9.4 \quad 11.2$

$36.6 \quad 31.3$

Investment

Servicing Fees

Securization

Sales of Assets

Other

TOTAL

100.0

100.0 
Figure 2.6: WV and U.S. Banks ROA, 2009-2017

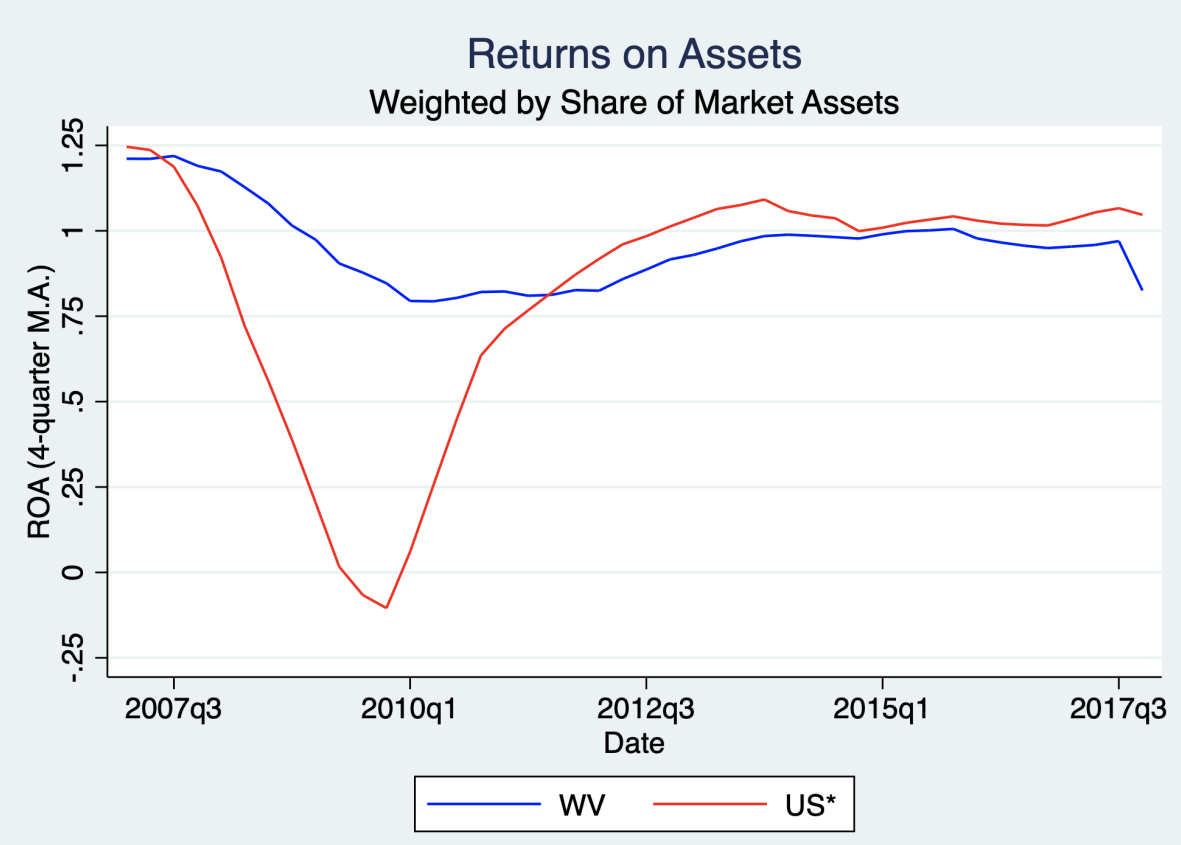


Figure 2.7: WV and US* Bank Liabilities by Market, 2017

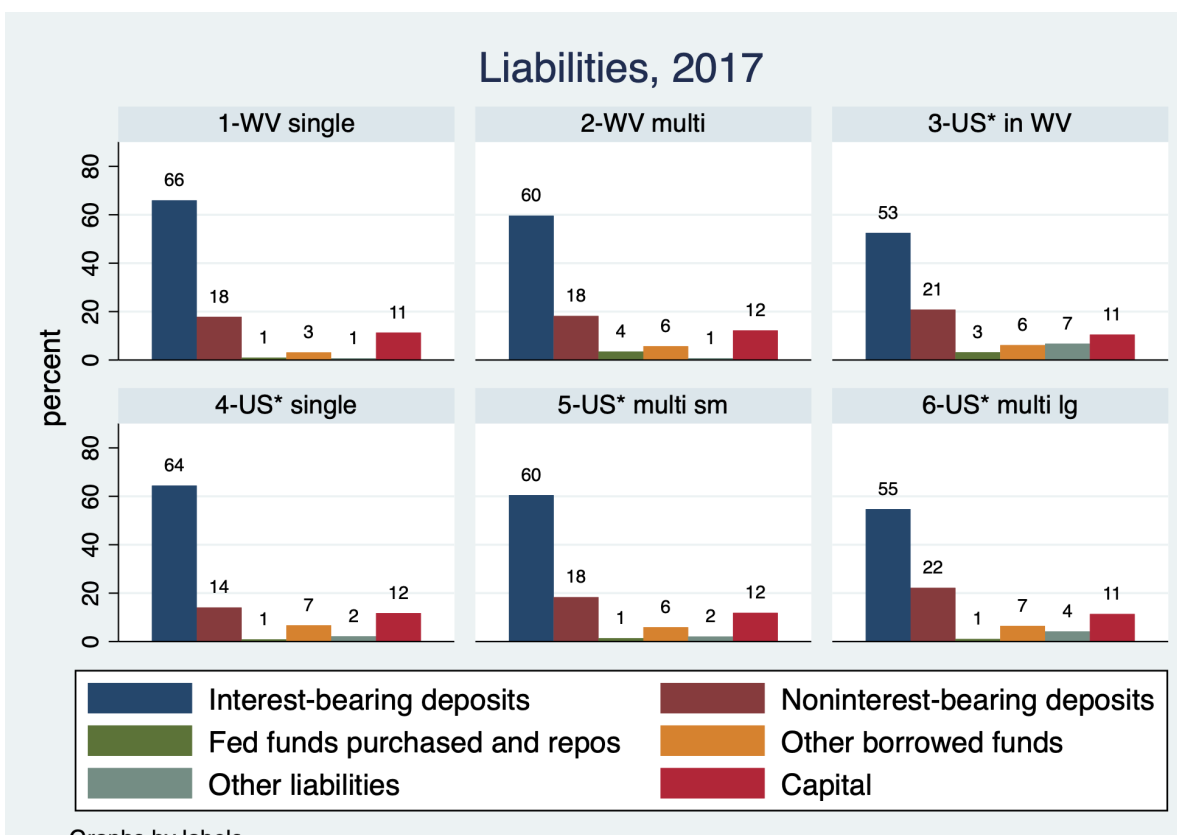


Figure 2.8: WV and US* Bank Non-transaction Accounts by Market, 2017

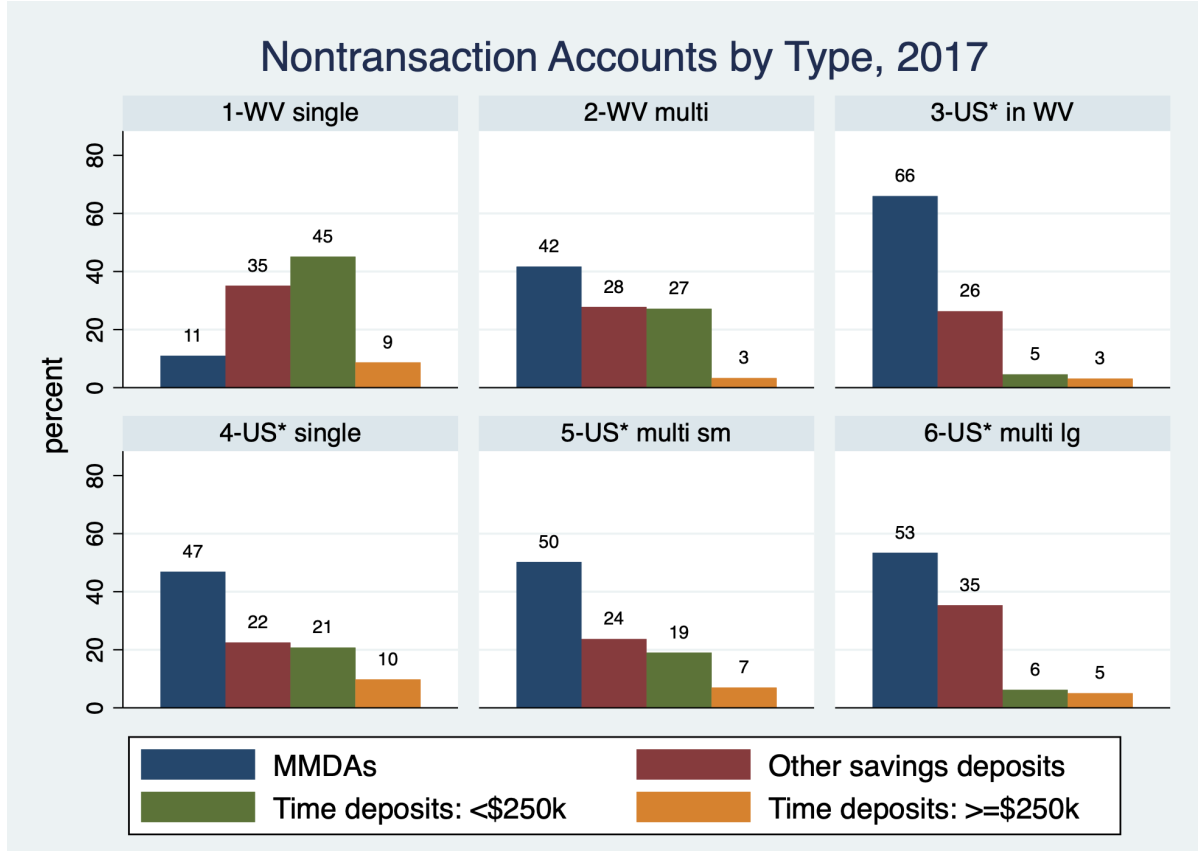


Figure 2.9: WV and US* Bank Assets by Market, 2017

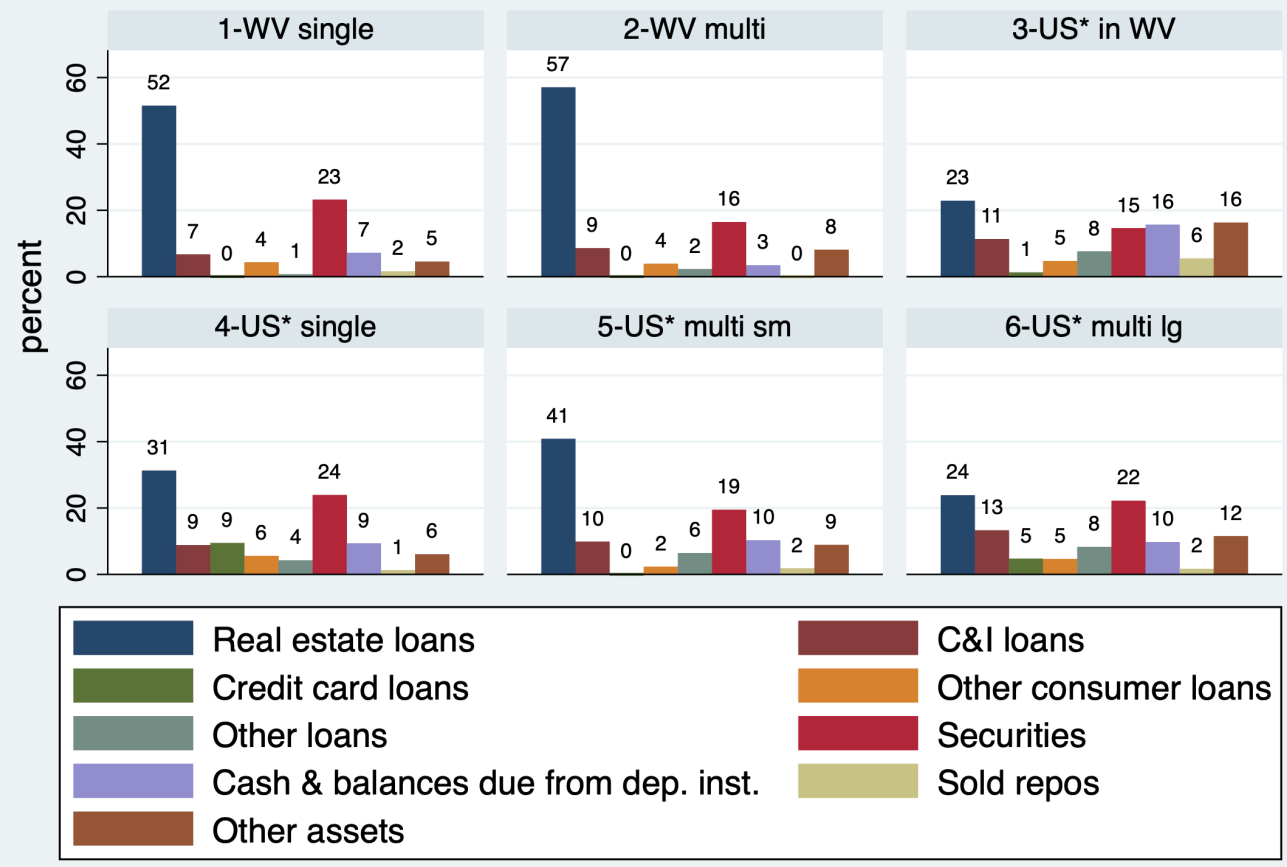

Graphs by labels 
Figure 2.10: WV and US* Bank Revenues by Market, 2017

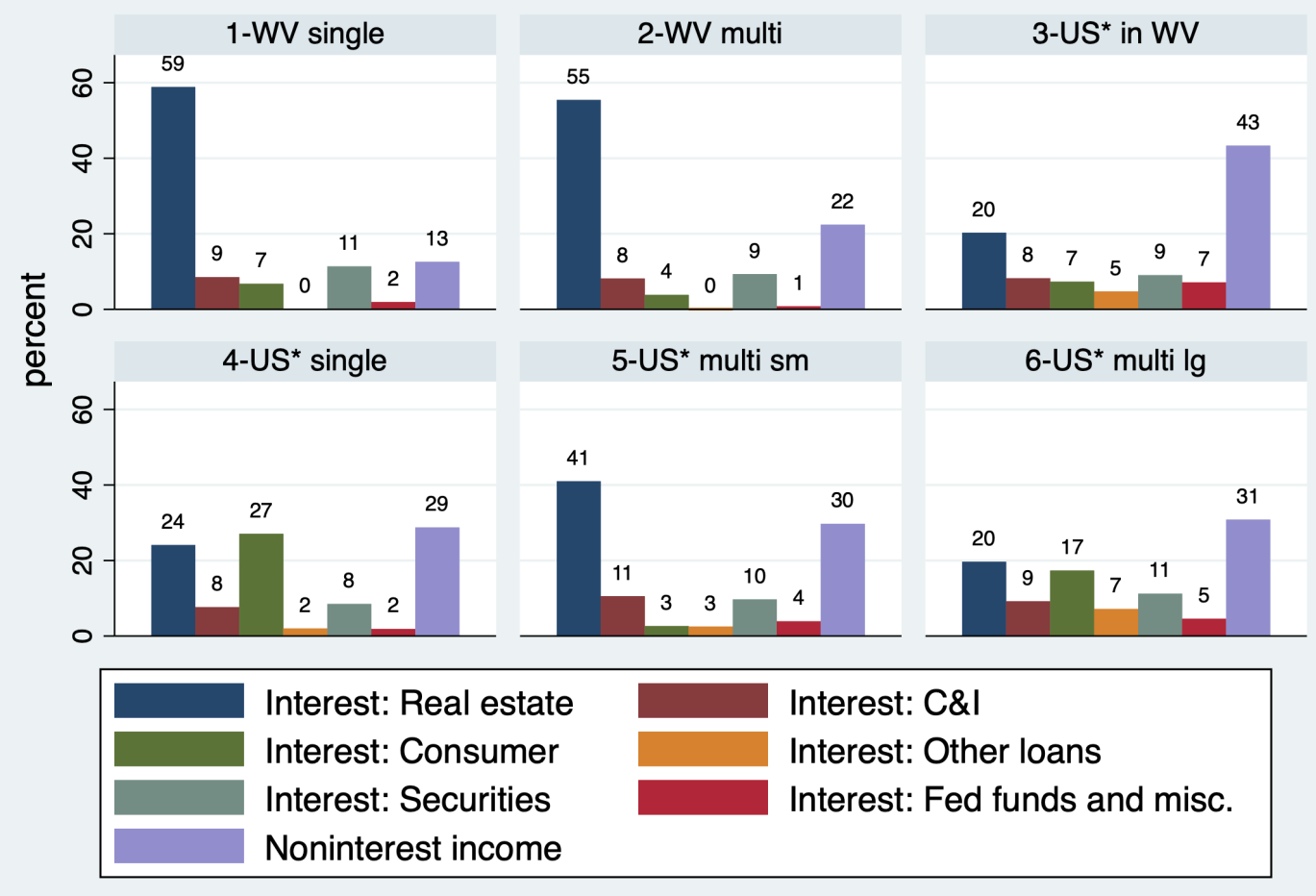

Graphs by labels 
Figure 2.11: WV and US* Bank Noninterest Income by Market, 2017

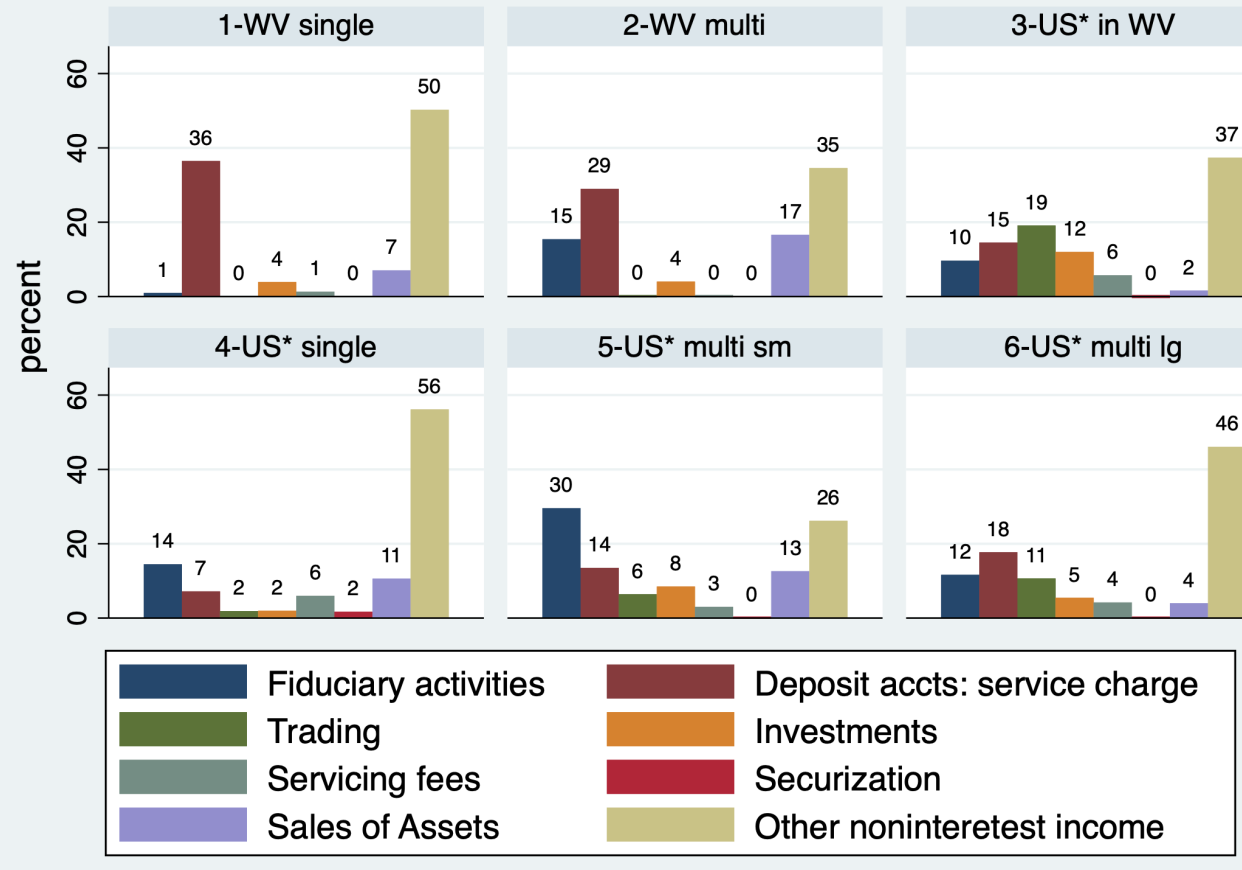

Graphs by labels 
Figure 2.12: WV and US* Bank ROA by Market, 2009-2017

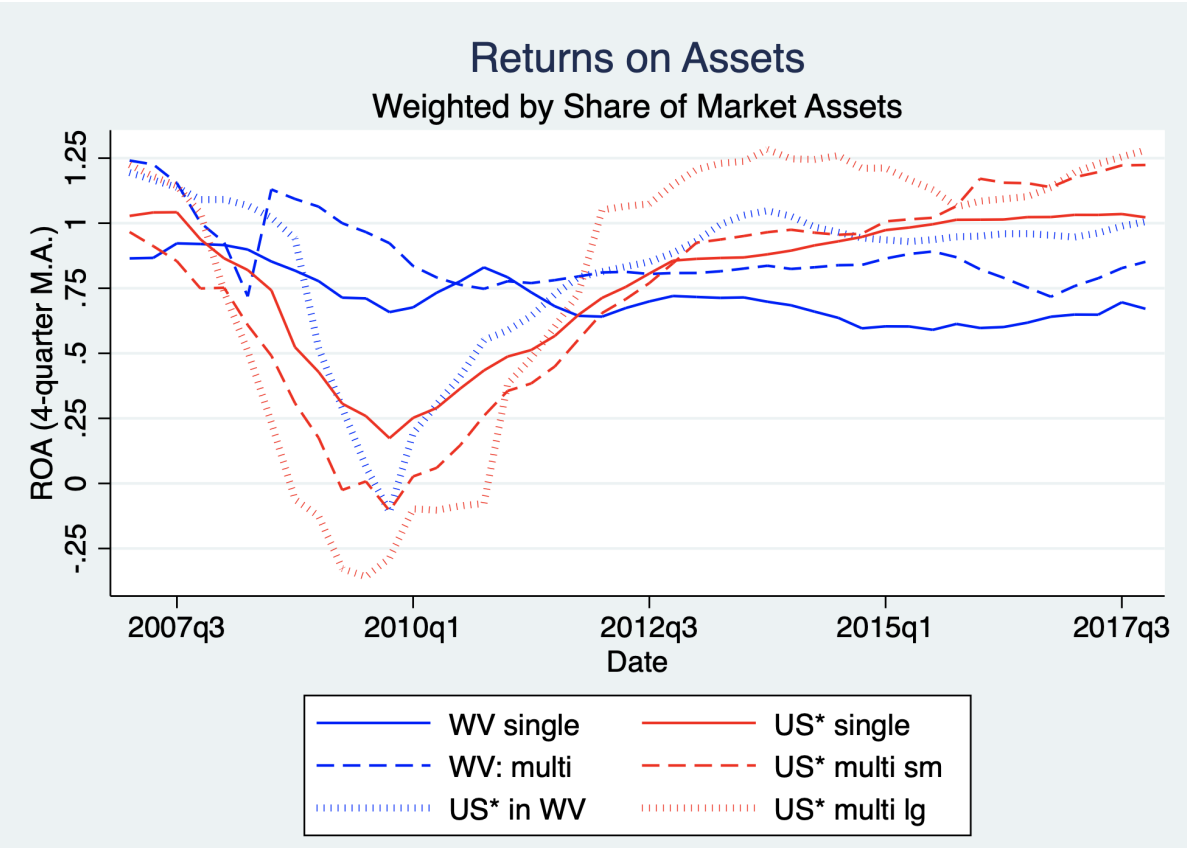


Table 2.3: Liabilites and Equity

\begin{tabular}{|c|c|c|c|c|c|c|}
\hline & \multicolumn{6}{|c|}{ Dependent Variable: } \\
\hline & $\begin{array}{l}\text { IntAccts } \\
\text { (1) }\end{array}$ & $\begin{array}{c}\text { NonIntAccts } \\
\text { (2) }\end{array}$ & $\begin{array}{l}\text { Frepp } \\
\text { (3) }\end{array}$ & $\begin{array}{c}\text { OthBorFunds } \\
\text { (4) }\end{array}$ & $\begin{array}{c}\text { OthLiab } \\
\text { (5) }\end{array}$ & $\begin{array}{l}\text { Capital } \\
\text { (6) }\end{array}$ \\
\hline $\mathrm{WV}$ & $\begin{array}{l}58.68^{* * *} \\
(2.65)\end{array}$ & $\begin{array}{l}15.77^{* * *} \\
(2.44)\end{array}$ & $\begin{array}{l}3.02^{* * *} \\
(0.43)\end{array}$ & $\begin{array}{l}8.65^{* * *} \\
(1.62)\end{array}$ & $\begin{array}{l}1.44^{* * *} \\
(0.51)\end{array}$ & $\begin{array}{l}12.43^{* * *} \\
(0.81)\end{array}$ \\
\hline US* & $\begin{array}{l}58.75^{* * *} \\
(0.80)\end{array}$ & $\begin{array}{l}16.22^{* * *} \\
(0.73)\end{array}$ & $\begin{array}{l}1.08^{* * *} \\
(0.13)\end{array}$ & $\begin{array}{l}9.50^{* * *} \\
(0.49)\end{array}$ & $\begin{array}{l}1.97^{* * *} \\
(0.15)\end{array}$ & $\begin{array}{l}12.47^{* * *} \\
(0.24)\end{array}$ \\
\hline Class: Nonmember & $\begin{array}{c}4.61 \\
(4.62)\end{array}$ & $\begin{array}{c}-0.15 \\
(4.26)\end{array}$ & $\begin{array}{c}0.49 \\
(0.75)\end{array}$ & $\begin{array}{c}-1.85 \\
(2.83)\end{array}$ & $\begin{array}{c}-0.37 \\
(0.90)\end{array}$ & $\begin{array}{r}-2.73^{*} \\
(1.41)\end{array}$ \\
\hline Class: State Member & $\begin{array}{c}-3.33^{* * *} \\
(0.39)\end{array}$ & $\begin{array}{l}7.98^{* * *} \\
(0.36)\end{array}$ & $\begin{array}{c}0.09 \\
(0.06)\end{array}$ & $\begin{array}{l}-4.08^{* * *} \\
(0.24)\end{array}$ & $\begin{array}{l}0.17^{* *} \\
(0.08)\end{array}$ & $\begin{array}{c}-0.82^{* * *} \\
(0.12)\end{array}$ \\
\hline Class: Savings Bank & $\begin{array}{r}8.16^{*} \\
(4.67)\end{array}$ & $\begin{array}{c}-6.14 \\
(4.31)\end{array}$ & $\begin{array}{c}0.24 \\
(0.76)\end{array}$ & $\begin{array}{l}1.93 \\
(2.87)\end{array}$ & $\begin{array}{c}-1.29 \\
(0.91)\end{array}$ & $\begin{array}{c}-2.90^{* *} \\
(1.43)\end{array}$ \\
\hline Class: Savings Assoc. & $\begin{array}{l}14.55^{* * *} \\
(0.92)\end{array}$ & $\begin{array}{c}-7.44^{* * *} \\
(0.85)\end{array}$ & $\begin{array}{c}-0.33^{* *} \\
(0.15)\end{array}$ & $\begin{array}{c}-3.59^{* * *} \\
(0.56)\end{array}$ & $\begin{array}{c}-0.77^{* * *} \\
(0.18)\end{array}$ & $\begin{array}{c}-2.41^{* * *} \\
(0.28)\end{array}$ \\
\hline Owned: Multi-BHC & $\begin{array}{l}3.82^{* * *} \\
(0.73)\end{array}$ & $\begin{array}{l}-5.82^{* * *} \\
(0.68)\end{array}$ & $\begin{array}{c}0.07 \\
(0.12)\end{array}$ & $\begin{array}{c}-0.55 \\
(0.45)\end{array}$ & $\begin{array}{l}1.87^{* * *} \\
(0.14)\end{array}$ & $\begin{array}{l}0.62^{* * *} \\
(0.22)\end{array}$ \\
\hline Owned: Single-BHC & $\begin{array}{l}2.71^{* * *} \\
(0.70)\end{array}$ & $\begin{array}{c}-0.99 \\
(0.65)\end{array}$ & $\begin{array}{l}0.27^{* *} \\
(0.12)\end{array}$ & $\begin{array}{c}-1.47^{* * *} \\
(0.43)\end{array}$ & $\begin{array}{c}-0.39^{* * *} \\
(0.14)\end{array}$ & $\begin{array}{c}-0.14 \\
(0.22)\end{array}$ \\
\hline Reg. by FDIC & $\begin{array}{l}-4.52 \\
(4.59)\end{array}$ & $\begin{array}{c}2.73 \\
(4.24)\end{array}$ & $\begin{array}{c}-0.49 \\
(0.75)\end{array}$ & $\begin{array}{c}-0.14 \\
(2.82)\end{array}$ & $\begin{array}{c}-0.05 \\
(0.89)\end{array}$ & $\begin{array}{r}2.48^{*} \\
(1.41)\end{array}$ \\
\hline Age: $0-10 \mathrm{yrs}$ & $\begin{array}{l}4.09^{* * *} \\
(0.55)\end{array}$ & $\begin{array}{c}-6.01^{* * *} \\
(0.51)\end{array}$ & $\begin{array}{c}-0.12 \\
(0.09)\end{array}$ & $\begin{array}{l}1.10^{* * *} \\
(0.34)\end{array}$ & $\begin{array}{l}0.25^{* *} \\
(0.11)\end{array}$ & $\begin{array}{l}0.68^{* * *} \\
(0.17)\end{array}$ \\
\hline Age: $10-20$ yrs & $\begin{array}{l}5.91^{* * *} \\
(0.52)\end{array}$ & $\begin{array}{c}-4.35^{* * *} \\
(0.48)\end{array}$ & $\begin{array}{c}-0.62^{* * *} \\
(0.09)\end{array}$ & $\begin{array}{c}-0.22 \\
(0.32)\end{array}$ & $\begin{array}{c}-0.56^{* * *} \\
(0.10)\end{array}$ & $\begin{array}{c}-0.16 \\
(0.16)\end{array}$ \\
\hline Bank Size: Nat. Share of Deposits & $\begin{array}{l}0.30^{* * *} \\
(0.06)\end{array}$ & $\begin{array}{c}-0.76^{* * *} \\
(0.06)\end{array}$ & $\begin{array}{l}0.30^{* * *} \\
(0.01)\end{array}$ & $\begin{array}{c}-0.15^{* * *} \\
(0.04)\end{array}$ & $\begin{array}{l}0.51^{* * *} \\
(0.01)\end{array}$ & $\begin{array}{c}-0.20^{* * *} \\
(0.02)\end{array}$ \\
\hline Market Size: Share of States & $\begin{array}{l}0.26^{* * *} \\
(0.02)\end{array}$ & $\begin{array}{r}-0.004 \\
(0.02)\end{array}$ & $\begin{array}{c}-0.06^{* * *} \\
(0.003)\end{array}$ & $\begin{array}{c}0.01 \\
(0.01)\end{array}$ & $\begin{array}{c}-0.22^{* * *} \\
(0.004)\end{array}$ & $\begin{array}{c}0.01^{*} \\
(0.01)\end{array}$ \\
\hline Market Size: Share of Pop. & $\begin{array}{c}-0.37^{* * *} \\
(0.02)\end{array}$ & $\begin{array}{l}0.26^{* * *} \\
(0.02)\end{array}$ & $\begin{array}{c}0.02^{* * *} \\
(0.003)\end{array}$ & $\begin{array}{r}-0.02^{*} \\
(0.01)\end{array}$ & $\begin{array}{c}0.13^{* * *} \\
(0.004)\end{array}$ & $\begin{array}{c}-0.02^{* * *} \\
(0.01)\end{array}$ \\
\hline WV coef. for base regression: & 61 & 18 & 2.9 & 5.1 & 0.76 & 12 \\
\hline US* coef. for base regression: & 57 & 20 & 1.5 & 6.4 & 4 & 11 \\
\hline F.E. Contribution: & 0.99 & 0.91 & 0.73 & 0.95 & 0.7 & 0.99 \\
\hline F-test: WV = US* (p-value) & 0.97 & 0.72 & 0.02 & 0.67 & 0.35 & 0.96 \\
\hline Adjusted $\mathrm{R}^{2}$ & 0.98 & 0.87 & 0.59 & 0.60 & 0.89 & 0.95 \\
\hline
\end{tabular}

Note: Sample size $=5,777$. Dependent variables are shares of total assets.

${ }^{*} \mathrm{p}<0.1 ;{ }^{* *} \mathrm{p}<0.05 ;{ }^{* * *} \mathrm{p}<0.01$ 
Table 2.4: Domestic Deposits

\begin{tabular}{|c|c|c|c|c|c|}
\hline & \multicolumn{5}{|c|}{ Dependent Variable: } \\
\hline & $\begin{array}{c}\text { TransDep } \\
(1) \\
\end{array}$ & $\begin{array}{c}\text { MMDAs } \\
\text { (2) }\end{array}$ & $\begin{array}{c}\text { OthSav } \\
\text { (3) } \\
\end{array}$ & $\begin{array}{c}\text { TmDep0-250k } \\
\text { (4) }\end{array}$ & $\begin{array}{c}\text { TmDep250k } \\
(5) \\
\end{array}$ \\
\hline WV & $\begin{array}{l}19.41^{* * *} \\
(2.37)\end{array}$ & $\begin{array}{l}16.01^{* * *} \\
(4.91)\end{array}$ & $\begin{array}{l}14.94^{* * *} \\
(3.47)\end{array}$ & $\begin{array}{l}18.67^{* * *} \\
(1.93)\end{array}$ & $\begin{array}{l}5.42^{* * *} \\
(1.42)\end{array}$ \\
\hline US* & $\begin{array}{l}14.45^{* * *} \\
(0.71)\end{array}$ & $\begin{array}{l}25.49^{* * *} \\
(1.48)\end{array}$ & $\begin{array}{l}13.81^{* * *} \\
(1.04)\end{array}$ & $\begin{array}{l}13.24^{* * *} \\
(0.58)\end{array}$ & $\begin{array}{l}7.23^{* * *} \\
(0.43)\end{array}$ \\
\hline Class: Nonmember & $\begin{array}{c}-9.52^{* *} \\
(4.14)\end{array}$ & $\begin{array}{l}30.24^{* * *} \\
(8.57)\end{array}$ & $\begin{array}{c}-2.00 \\
(6.05)\end{array}$ & $\begin{array}{c}-10.28^{* * *} \\
(3.36)\end{array}$ & $\begin{array}{c}-2.84 \\
(2.48)\end{array}$ \\
\hline Class: State Member & $\begin{array}{l}3.48^{* * *} \\
(0.35)\end{array}$ & $\begin{array}{c}-3.25^{* * *} \\
(0.72)\end{array}$ & $\begin{array}{c}-3.84^{* * *} \\
(0.51)\end{array}$ & $\begin{array}{l}0.68^{* *} \\
(0.28)\end{array}$ & $\begin{array}{c}-0.55^{* * *} \\
(0.21)\end{array}$ \\
\hline Class: Savings Bank & $\begin{array}{c}-13.85^{* * *} \\
(4.19)\end{array}$ & $\begin{array}{c}21.55^{* *} \\
(8.67)\end{array}$ & $\begin{array}{c}9.79 \\
(6.13)\end{array}$ & $\begin{array}{c}-7.98^{* *} \\
(3.40)\end{array}$ & $\begin{array}{c}-3.87 \\
(2.51)\end{array}$ \\
\hline Class: Savings Assoc. & $\begin{array}{c}-3.34^{* * *} \\
(0.82)\end{array}$ & $\begin{array}{l}13.25^{* * *} \\
(1.70)\end{array}$ & $\begin{array}{c}-0.005 \\
(1.20)\end{array}$ & $\begin{array}{c}-2.58^{* * *} \\
(0.67)\end{array}$ & $\begin{array}{c}-3.14^{* * *} \\
(0.49)\end{array}$ \\
\hline Owned: Multi-BHC & $\begin{array}{c}-3.10^{* * *} \\
(0.66)\end{array}$ & $\begin{array}{l}4.96^{* * *} \\
(1.36)\end{array}$ & $\begin{array}{c}-4.99^{* * *} \\
(0.96)\end{array}$ & $\begin{array}{c}-6.90^{* * *} \\
(0.54)\end{array}$ & $\begin{array}{c}0.34 \\
(0.39)\end{array}$ \\
\hline Owned: Single-BHC & $\begin{array}{c}-1.50^{* *} \\
(0.63)\end{array}$ & $\begin{array}{l}6.63^{* * *} \\
(1.31)\end{array}$ & $\begin{array}{l}3.54^{* * *} \\
(0.92)\end{array}$ & $\begin{array}{c}-1.98^{* * *} \\
(0.51)\end{array}$ & $\begin{array}{c}-1.81^{* * *} \\
(0.38)\end{array}$ \\
\hline Reg. by FDIC & $\begin{array}{l}11.93^{* * *} \\
(4.12)\end{array}$ & $\begin{array}{c}-35.64^{* * *} \\
(8.53)\end{array}$ & $\begin{array}{c}2.26 \\
(6.02)\end{array}$ & $\begin{array}{l}15.02^{* * *} \\
(3.35)\end{array}$ & $\begin{array}{c}1.96 \\
(2.47)\end{array}$ \\
\hline Age: $0-10$ yrs & $\begin{array}{c}-4.34^{* * *} \\
(0.49)\end{array}$ & $\begin{array}{l}3.04^{* * *} \\
(1.02)\end{array}$ & $\begin{array}{l}2.00^{* * *} \\
(0.72)\end{array}$ & $\begin{array}{l}4.96^{* * *} \\
(0.40)\end{array}$ & $\begin{array}{c}-1.45^{* * *} \\
(0.29)\end{array}$ \\
\hline Age: $10-20$ yrs & $\begin{array}{c}-2.17^{* * *} \\
(0.47)\end{array}$ & $\begin{array}{l}7.03^{* * *} \\
(0.97)\end{array}$ & $\begin{array}{l}1.80^{* * *} \\
(0.68)\end{array}$ & $\begin{array}{c}0.59 \\
(0.38)\end{array}$ & $\begin{array}{c}-2.16^{* * *} \\
(0.28)\end{array}$ \\
\hline Bank Size: Nat. Share of Deposits & $\begin{array}{l}0.63^{* * *} \\
(0.05)\end{array}$ & $\begin{array}{c}-3.02^{* * *} \\
(0.11)\end{array}$ & $\begin{array}{l}0.41^{* * *} \\
(0.08)\end{array}$ & $\begin{array}{l}0.22^{* * *} \\
(0.04)\end{array}$ & $\begin{array}{l}0.08^{* *} \\
(0.03)\end{array}$ \\
\hline Market Size: Share of States & $\begin{array}{c}-0.10^{* * *} \\
(0.02)\end{array}$ & $\begin{array}{l}0.15^{* * *} \\
(0.04)\end{array}$ & $\begin{array}{l}0.80^{* * *} \\
(0.03)\end{array}$ & $\begin{array}{l}0.22^{* * *} \\
(0.01)\end{array}$ & $\begin{array}{c}-0.002 \\
(0.01)\end{array}$ \\
\hline Market Size: Share of Pop. & $\begin{array}{c}0.01 \\
(0.02)\end{array}$ & $\begin{array}{l}0.22^{* * *} \\
(0.04)\end{array}$ & $\begin{array}{c}-0.51^{* * *} \\
(0.03)\end{array}$ & $\begin{array}{c}-0.26^{* * *} \\
(0.01)\end{array}$ & $\begin{array}{c}-0.08^{* * *} \\
(0.01)\end{array}$ \\
\hline WV coef. for base regression: & 19 & 21 & 18 & 19 & 2.7 \\
\hline US* coef. for base regression: & 12 & 30 & 17 & 6.2 & 3.4 \\
\hline F.E. Contribution: & 0.96 & 0.94 & 0.84 & 0.56 & 0.8 \\
\hline F-test: WV = US* (p-value) & 0.38 & 0.16 & 0.74 & 0.05 & 0.07 \\
\hline Adjusted $\mathrm{R}^{2}$ & 0.72 & 0.79 & 0.72 & 0.63 & 0.40 \\
\hline
\end{tabular}

Note: Sample size $=5,777$. Dependent variables are shares of total assets.

${ }^{*} \mathrm{p}<0.1 ;{ }^{* *} \mathrm{p}<0.05 ;{ }^{* * *} \mathrm{p}<0.01$ 
Table 2.5: Assets

\begin{tabular}{|c|c|c|c|c|c|}
\hline & \multicolumn{5}{|c|}{ Dependent Variable: } \\
\hline & $\begin{array}{c}\text { RealEstLns } \\
(1) \\
\end{array}$ & $\begin{array}{c}\text { CILns } \\
(2)\end{array}$ & $\begin{array}{c}\text { CrCdLns } \\
\text { (3) }\end{array}$ & $\begin{array}{c}\text { OthConsLns } \\
\text { (4) } \\
\end{array}$ & $\begin{array}{c}\text { OthLns } \\
(5) \\
\end{array}$ \\
\hline WV & $\begin{array}{l}55.15^{* * *} \\
(3.97)\end{array}$ & $\begin{array}{c}0.11 \\
(1.90)\end{array}$ & $\begin{array}{c}6.10^{*} \\
(3.48)\end{array}$ & $\begin{array}{l}3.97^{* *} \\
(1.81)\end{array}$ & $\begin{array}{c}0.61 \\
(1.17)\end{array}$ \\
\hline US* & $\begin{array}{l}38.45^{* * *} \\
(1.19)\end{array}$ & $\begin{array}{l}2.62^{* * *} \\
(0.57)\end{array}$ & $\begin{array}{l}12.56^{* * *} \\
(1.05)\end{array}$ & $\begin{array}{l}5.24^{* * *} \\
(0.54)\end{array}$ & $\begin{array}{l}3.66^{* * *} \\
(0.35)\end{array}$ \\
\hline Class: Nonmember & $\begin{array}{c}-26.60^{* * *} \\
(6.93)\end{array}$ & $\begin{array}{c}-0.88 \\
(3.32)\end{array}$ & $\begin{array}{r}9.99^{*} \\
(6.06)\end{array}$ & $\begin{array}{c}3.92 \\
(3.15)\end{array}$ & $\begin{array}{c}1.51 \\
(2.03)\end{array}$ \\
\hline Class: State Member & $\begin{array}{c}-3.23^{* * *} \\
(0.58)\end{array}$ & $\begin{array}{r}-0.51^{*} \\
(0.28)\end{array}$ & $\begin{array}{c}-7.21^{* * *} \\
(0.51)\end{array}$ & $\begin{array}{c}-0.34 \\
(0.27)\end{array}$ & $\begin{array}{l}0.67^{* * *} \\
(0.17)\end{array}$ \\
\hline Class: Savings Bank & $\begin{array}{c}-6.07 \\
(7.01)\end{array}$ & $\begin{array}{c}0.08 \\
(3.36)\end{array}$ & $\begin{array}{c}1.65 \\
(6.14)\end{array}$ & $\begin{array}{c}0.43 \\
(3.19)\end{array}$ & $\begin{array}{c}-1.42 \\
(2.06)\end{array}$ \\
\hline Class: Savings Assoc. & $\begin{array}{c}-14.99^{* * *} \\
(1.38)\end{array}$ & $\begin{array}{c}-2.04^{* * *} \\
(0.66)\end{array}$ & $\begin{array}{l}7.48^{* * *} \\
(1.21)\end{array}$ & $\begin{array}{c}-2.18^{* * *} \\
(0.63)\end{array}$ & $\begin{array}{c}-2.92^{* * *} \\
(0.40)\end{array}$ \\
\hline Owned: Multi-BHC & $\begin{array}{c}-20.12^{* * *} \\
(1.10)\end{array}$ & $\begin{array}{l}7.60^{* * *} \\
(0.53)\end{array}$ & $\begin{array}{l}3.34^{* * *} \\
(0.96)\end{array}$ & $\begin{array}{c}0.24 \\
(0.50)\end{array}$ & $\begin{array}{l}2.83^{* * *} \\
(0.32)\end{array}$ \\
\hline Owned: Single-BHC & $\begin{array}{c}1.03 \\
(1.06)\end{array}$ & $\begin{array}{l}9.97^{* * *} \\
(0.51)\end{array}$ & $\begin{array}{c}-4.18^{* * *} \\
(0.93)\end{array}$ & $\begin{array}{c}-1.63^{* * *} \\
(0.48)\end{array}$ & $\begin{array}{l}1.63^{* * *} \\
(0.31)\end{array}$ \\
\hline Reg. by FDIC & $\begin{array}{l}33.49^{* * *} \\
(6.90)\end{array}$ & $\begin{array}{c}-3.08 \\
(3.30)\end{array}$ & $\begin{array}{r}-10.18^{*} \\
(6.04)\end{array}$ & $\begin{array}{c}-3.41 \\
(3.14)\end{array}$ & $\begin{array}{c}-2.68 \\
(2.02)\end{array}$ \\
\hline Age: $0-10 \mathrm{yrs}$ & $\begin{array}{l}11.42^{* * *} \\
(0.82)\end{array}$ & $\begin{array}{l}2.97^{* * *} \\
(0.39)\end{array}$ & $\begin{array}{c}-9.01^{* * *} \\
(0.72)\end{array}$ & $\begin{array}{r}0.73^{*} \\
(0.37)\end{array}$ & $\begin{array}{l}1.95^{* * *} \\
(0.24)\end{array}$ \\
\hline Age: $10-20 \mathrm{yrs}$ & $\begin{array}{c}-4.19^{* * *} \\
(0.78)\end{array}$ & $\begin{array}{l}6.94^{* * *} \\
(0.38)\end{array}$ & $\begin{array}{c}-5.67^{* * *} \\
(0.69)\end{array}$ & $\begin{array}{l}7.19^{* * *} \\
(0.36)\end{array}$ & $\begin{array}{c}-1.29^{* * *} \\
(0.23)\end{array}$ \\
\hline Bank Size: Nat. Share of Deposits & $\begin{array}{c}-1.23^{* * *} \\
(0.09)\end{array}$ & $\begin{array}{c}-1.24^{* * *} \\
(0.04)\end{array}$ & $\begin{array}{l}0.56^{* * *} \\
(0.08)\end{array}$ & $\begin{array}{c}-0.30^{* * *} \\
(0.04)\end{array}$ & $\begin{array}{c}-0.13^{\text {*** }} \\
(0.03)\end{array}$ \\
\hline Market Size: Share of States & $\begin{array}{l}0.35^{* * *} \\
(0.03)\end{array}$ & $\begin{array}{c}-0.04^{* * *} \\
(0.01)\end{array}$ & $\begin{array}{l}0.14^{* * *} \\
(0.03)\end{array}$ & $\begin{array}{l}0.19^{* * *} \\
(0.01)\end{array}$ & $\begin{array}{c}-0.05^{* * *} \\
(0.01)\end{array}$ \\
\hline Market Size: Share of Pop. & $\begin{array}{c}-0.09^{* * *} \\
(0.03)\end{array}$ & $\begin{array}{l}0.20^{* * *} \\
(0.01)\end{array}$ & $\begin{array}{c}-0.33^{* * *} \\
(0.03)\end{array}$ & $\begin{array}{c}-0.13^{* * *} \\
(0.01)\end{array}$ & $\begin{array}{l}0.08^{* * *} \\
(0.01)\end{array}$ \\
\hline WV coef. for base regression: & 56 & 8.2 & 0.066 & 4 & 2 \\
\hline US* coef. for base regression: & 27 & 12 & 4.6 & 4.6 & 7.1 \\
\hline F.E. Contribution: & 0.83 & 0.9 & 0.45 & 0.79 & 0.91 \\
\hline F-test: WV $=$ US* (p-value) & 0.00 & 0.09 & 0.00 & 0.33 & 0.00 \\
\hline Adjusted $\mathrm{R}^{2}$ & 0.84 & 0.79 & 0.26 & 0.43 & 0.79 \\
\hline
\end{tabular}

Note: Sample size $=5,777$. Dependent variables are shares of total assets.

${ }^{*} \mathrm{p}<0.1 ;{ }^{* *} \mathrm{p}<0.05 ;{ }^{* * *} \mathrm{p}<0.01$ 
Assets (continued)

\begin{tabular}{|c|c|c|c|c|}
\hline & \multicolumn{4}{|c|}{ Dependent Variable: } \\
\hline & $\begin{array}{l}\text { Sct } \\
(1)\end{array}$ & $\begin{array}{c}\mathrm{ChBal} \\
(2)\end{array}$ & $\begin{array}{c}\text { Frepo } \\
(3) \\
\end{array}$ & $\begin{array}{c}\text { OthAssets } \\
(4)\end{array}$ \\
\hline WV & $\begin{array}{l}26.58^{* * *} \\
(3.42)\end{array}$ & $\begin{array}{c}1.29 \\
(1.89)\end{array}$ & $\begin{array}{c}0.84 \\
(1.12)\end{array}$ & $\begin{array}{l}6.53^{* * *} \\
(0.99)\end{array}$ \\
\hline US* & $\begin{array}{l}29.19^{* * *} \\
(1.03)\end{array}$ & $\begin{array}{l}3.39^{* * *} \\
(0.57)\end{array}$ & $\begin{array}{l}0.68^{* *} \\
(0.34)\end{array}$ & $\begin{array}{l}5.70^{* * * *} \\
(0.30)\end{array}$ \\
\hline Class: Nonmember & $\begin{array}{l}11.98^{* *} \\
(5.97)\end{array}$ & $\begin{array}{c}2.77 \\
(3.29)\end{array}$ & $\begin{array}{c}-0.18 \\
(1.96)\end{array}$ & $\begin{array}{c}-2.30 \\
(1.72)\end{array}$ \\
\hline Class: State Member & $\begin{array}{l}1.03^{* *} \\
(0.50)\end{array}$ & $\begin{array}{l}7.23^{* * *} \\
(0.28)\end{array}$ & $\begin{array}{l}0.80^{* * *} \\
(0.17)\end{array}$ & $\begin{array}{l}1.19^{\text {*** }} \\
(0.15)\end{array}$ \\
\hline Class: Savings Bank & $\begin{array}{c}8.81 \\
(6.05)\end{array}$ & $\begin{array}{c}-0.11 \\
(3.34)\end{array}$ & $\begin{array}{c}-0.70 \\
(1.98)\end{array}$ & $\begin{array}{c}-2.85 \\
(1.74)\end{array}$ \\
\hline Class: Savings Assoc. & $\begin{array}{l}16.51^{* * *} \\
(1.19)\end{array}$ & $\begin{array}{l}3.55^{\text {*** }} \\
(0.66)\end{array}$ & $\begin{array}{c}-1.39^{* * *} \\
(0.39)\end{array}$ & $\begin{array}{c}-3.94^{* * *} \\
(0.34)\end{array}$ \\
\hline Owned: Multi-BHC & $\begin{array}{c}-6.11^{* * *} \\
(0.95)\end{array}$ & $\begin{array}{l}6.72 * * * \\
(0.52)\end{array}$ & $\begin{array}{l}1.48^{* * *} \\
(0.31)\end{array}$ & $\begin{array}{l}3.68^{* * *} \\
(0.27)\end{array}$ \\
\hline Owned: Single-BHC & $\begin{array}{c}-6.42^{* * *} \\
(0.91)\end{array}$ & $\begin{array}{c}-1.64^{* * *} \\
(0.50)\end{array}$ & $\begin{array}{c}-0.38 \\
(0.30)\end{array}$ & $\begin{array}{l}1.28^{* * *} \\
(0.26)\end{array}$ \\
\hline Reg. by FDIC & $\begin{array}{c}-17.10^{* * *} \\
(5.95)\end{array}$ & $\begin{array}{c}0.84 \\
(3.28)\end{array}$ & $\begin{array}{c}0.12 \\
(1.95)\end{array}$ & $\begin{array}{c}1.72 \\
(1.71)\end{array}$ \\
\hline Age: $0-10$ yrs & $\begin{array}{c}-12.61^{* * *} \\
(0.71)\end{array}$ & $\begin{array}{l}0.81^{* *} \\
(0.39)\end{array}$ & $\begin{array}{l}1.08^{* * *} \\
(0.23)\end{array}$ & $\begin{array}{l}2.12^{\text {*** }} \\
(0.20)\end{array}$ \\
\hline Age: $10-20$ yrs & $\begin{array}{c}0.35 \\
(0.68)\end{array}$ & $\begin{array}{c}-2.10^{* * *} \\
(0.37)\end{array}$ & $\begin{array}{c}-0.49^{* *} \\
(0.22)\end{array}$ & $\begin{array}{c}-1.05^{* * *} \\
(0.19)\end{array}$ \\
\hline Bank Size: Nat. Share of Deposits & $\begin{array}{c}-0.38^{* * *} \\
(0.08)\end{array}$ & $\begin{array}{l}1.20^{* * *} \\
(0.04)\end{array}$ & $\begin{array}{l}0.61^{* * *} \\
(0.03)\end{array}$ & $\begin{array}{l}0.91^{* * * *} \\
(0.02)\end{array}$ \\
\hline Market Size: Share of States & $\begin{array}{l}0.21^{* * *} \\
(0.03)\end{array}$ & $\begin{array}{c}-0.30^{* * *} \\
(0.01)\end{array}$ & $\begin{array}{c}-0.18^{* * *} \\
(0.01)\end{array}$ & $\begin{array}{c}-0.31^{* * *} \\
(0.01)\end{array}$ \\
\hline Market Size: Share of Pop. & $\begin{array}{c}-0.15^{\text {*** }} \\
(0.03)\end{array}$ & $\begin{array}{l}0.13^{* * *} \\
(0.01)\end{array}$ & $\begin{array}{l}0.09^{* * *} \\
(0.01)\end{array}$ & $\begin{array}{l}0.19^{* * *} \\
(0.01)\end{array}$ \\
\hline WV coef. for base regression: & 18 & 4.3 & 0.39 & 7.4 \\
\hline WV coef. for base regression: & 21 & 11 & 2.4 & 11 \\
\hline F.E. Contribution: & 0.95 & 0.8 & 0.49 & 0.85 \\
\hline F-test: $\mathrm{WV}=\mathrm{US}^{*}(\mathrm{p}$-value $)$ & 0.49 & 0.15 & 0.78 & 0.63 \\
\hline Adjusted $\mathrm{R}^{2}$ & 0.78 & 0.79 & 0.45 & 0.93 \\
\hline
\end{tabular}

Note: Sample size $=5,777$. Dependent variables are shares of total assets.

${ }^{*} \mathrm{p}<0.1 ;{ }^{* *} \mathrm{p}<0.05 ;{ }^{* * *} \mathrm{p}<0.01$ 
Table 2.6: Real Estate Loans

\begin{tabular}{|c|c|c|c|c|c|c|}
\hline & \multicolumn{6}{|c|}{ Dependent Variable: } \\
\hline & $\begin{array}{c}\text { ConstDev } \\
\text { (1) } \\
\end{array}$ & $\begin{array}{l}\text { Agric } \\
(2) \\
\end{array}$ & $\begin{array}{c}\text { 1-4FamRes } \\
\text { (3) } \\
\end{array}$ & $\begin{array}{c}\text { 5+FamRes } \\
(4) \\
\end{array}$ & $\begin{array}{c}\text { NResNFarm } \\
(5) \\
\end{array}$ & $\begin{array}{c}\text { Foreign } \\
(6) \\
\end{array}$ \\
\hline WV & $\begin{array}{l}5.11^{* * *} \\
(0.62)\end{array}$ & $\begin{array}{c}-0.02 \\
(0.64)\end{array}$ & $\begin{array}{l}34.18^{* * *} \\
(2.19)\end{array}$ & $\begin{array}{l}4.54^{* * *} \\
(1.51)\end{array}$ & $\begin{array}{l}14.54^{* * *} \\
(1.71)\end{array}$ & $\begin{array}{c}0.17 \\
(0.12)\end{array}$ \\
\hline US* & $\begin{array}{l}4.58^{* * *} \\
(0.22)\end{array}$ & $\begin{array}{l}2.39^{* * *} \\
(0.23)\end{array}$ & $\begin{array}{l}23.70^{* * *} \\
(0.78)\end{array}$ & $\begin{array}{l}3.97^{* * *} \\
(0.54)\end{array}$ & $\begin{array}{l}15.96^{* * *} \\
(0.61)\end{array}$ & $\begin{array}{l}0.19^{* * *} \\
(0.04)\end{array}$ \\
\hline Class: Nonmember & $\begin{array}{c}1.78^{*} \\
(0.97)\end{array}$ & $\begin{array}{c}0.53 \\
(1.01)\end{array}$ & $\begin{array}{c}-9.08^{* * *} \\
(3.43)\end{array}$ & $\begin{array}{c}-0.59 \\
(2.37)\end{array}$ & $\begin{array}{l}7.09^{* * *} \\
(2.68)\end{array}$ & $\begin{array}{c}-0.12 \\
(0.18)\end{array}$ \\
\hline Class: State Member & $\begin{array}{l}1.34^{* * *} \\
(0.13)\end{array}$ & $\begin{array}{c}-0.09 \\
(0.14)\end{array}$ & $\begin{array}{r}-0.78^{*} \\
(0.46)\end{array}$ & $\begin{array}{c}0.24 \\
(0.32)\end{array}$ & $\begin{array}{l}2.56^{* * *} \\
(0.36)\end{array}$ & $\begin{array}{c}-0.14^{* * *} \\
(0.02)\end{array}$ \\
\hline Class: Savings Bank & $\begin{array}{c}-0.33 \\
(0.99)\end{array}$ & $\begin{array}{c}-2.05^{* *} \\
(1.02)\end{array}$ & $\begin{array}{l}1.01 \\
(3.48)\end{array}$ & $\begin{array}{l}11.72^{* * *} \\
(2.40)\end{array}$ & $\begin{array}{c}3.75 \\
(2.72)\end{array}$ & $\begin{array}{c}-0.22 \\
(0.18)\end{array}$ \\
\hline Class: Savings Assoc. & $\begin{array}{c}-1.32^{* * *} \\
(0.28)\end{array}$ & $\begin{array}{c}-0.43 \\
(0.29)\end{array}$ & $\begin{array}{l}12.08^{* * *} \\
(0.99)\end{array}$ & $\begin{array}{c}-0.60 \\
(0.68)\end{array}$ & $\begin{array}{c}-2.76^{* * *} \\
(0.77)\end{array}$ & $\begin{array}{c}-0.11^{* *} \\
(0.05)\end{array}$ \\
\hline Owned: Multi-BHC & $\begin{array}{c}-1.68^{* * *} \\
(0.20)\end{array}$ & $\begin{array}{c}-0.16 \\
(0.21)\end{array}$ & $\begin{array}{c}-8.45^{* * *} \\
(0.72)\end{array}$ & $\begin{array}{c}-1.23^{* *} \\
(0.49)\end{array}$ & $\begin{array}{c}-4.41^{* * *} \\
(0.56)\end{array}$ & $\begin{array}{l}0.19^{* * *} \\
(0.04)\end{array}$ \\
\hline Owned: Single-BHC & $\begin{array}{c}-0.50^{* * *} \\
(0.18)\end{array}$ & $\begin{array}{l}0.51^{* * *} \\
(0.19)\end{array}$ & $\begin{array}{c}-4.30^{* * *} \\
(0.65)\end{array}$ & $\begin{array}{c}-2.12^{* * *} \\
(0.45)\end{array}$ & $\begin{array}{l}2.17^{* * *} \\
(0.51)\end{array}$ & $\begin{array}{c}-0.04 \\
(0.03)\end{array}$ \\
\hline Reg. by FDIC & $\begin{array}{c}-0.23 \\
(0.97)\end{array}$ & $\begin{array}{c}0.42 \\
(1.00)\end{array}$ & $\begin{array}{l}7.14^{* *} \\
(3.40)\end{array}$ & $\begin{array}{c}2.77 \\
(2.35)\end{array}$ & $\begin{array}{c}-0.55 \\
(2.66)\end{array}$ & $\begin{array}{c}0.03 \\
(0.18)\end{array}$ \\
\hline Age: $0-10 \mathrm{yrs}$ & $\begin{array}{c}-0.68^{* * *} \\
(0.16)\end{array}$ & $\begin{array}{c}-1.30^{* * *} \\
(0.17)\end{array}$ & $\begin{array}{l}7.98^{* * *} \\
(0.58)\end{array}$ & $\begin{array}{l}2.68^{* * *} \\
(0.40)\end{array}$ & $\begin{array}{c}-3.22^{* * *} \\
(0.45)\end{array}$ & $\begin{array}{c}-0.09^{* * *} \\
(0.03)\end{array}$ \\
\hline Age: $10-20 \mathrm{yrs}$ & $\begin{array}{l}0.63^{* * *} \\
(0.16)\end{array}$ & $\begin{array}{c}-1.69^{* * *} \\
(0.16)\end{array}$ & $\begin{array}{c}-3.95^{* * *} \\
(0.55)\end{array}$ & $\begin{array}{l}0.94^{* *} \\
(0.38)\end{array}$ & $\begin{array}{l}2.79^{* * *} \\
(0.43)\end{array}$ & $\begin{array}{c}-0.07^{* *} \\
(0.03)\end{array}$ \\
\hline Bank Size: Nat. Share of Dep. & $\begin{array}{c}-0.07^{* * *} \\
(0.02)\end{array}$ & $\begin{array}{l}0.24^{* * *} \\
(0.02)\end{array}$ & $\begin{array}{c}-0.42^{* * *} \\
(0.07)\end{array}$ & $\begin{array}{c}-0.14^{* * *} \\
(0.05)\end{array}$ & $\begin{array}{c}-0.29^{* * *} \\
(0.06)\end{array}$ & $\begin{array}{c}0.07^{* * *} \\
(0.004)\end{array}$ \\
\hline Market Size: Share of States & $\begin{array}{l}0.06^{* * *} \\
(0.01)\end{array}$ & $\begin{array}{l}0.09^{* * *} \\
(0.01)\end{array}$ & $\begin{array}{l}0.29^{* * *} \\
(0.02)\end{array}$ & $\begin{array}{c}-0.17^{* * *} \\
(0.02)\end{array}$ & $\begin{array}{l}0.17^{* * *} \\
(0.02)\end{array}$ & $\begin{array}{c}-0.02^{* * *} \\
(0.001)\end{array}$ \\
\hline Market Size: Share of Pop. & $\begin{array}{c}-0.07^{* * *} \\
(0.01)\end{array}$ & $\begin{array}{c}-0.12^{* * *} \\
(0.01)\end{array}$ & $\begin{array}{c}-0.18^{* * *} \\
(0.02)\end{array}$ & $\begin{array}{l}0.13^{* * *} \\
(0.02)\end{array}$ & $\begin{array}{c}-0.20^{* * *} \\
(0.02)\end{array}$ & $\begin{array}{c}0.01^{* * *} \\
(0.001)\end{array}$ \\
\hline WV coef. for base regression: & 5.6 & 0.38 & 29 & 4 & 20 & 0 \\
\hline US* coef. for base regression: & 3 & 0.97 & 19 & 3.9 & 13 & 0.19 \\
\hline F.E. Contribution: & 0.73 & 0.36 & 0.88 & 0.52 & 0.73 & 0.33 \\
\hline F-test: WV = US* (p-value) & 0.59 & 0.00 & 0.00 & 0.41 & 0.52 & 0.61 \\
\hline Adjusted $\mathrm{R}^{2}$ & 0.60 & 0.23 & 0.79 & 0.38 & 0.78 & 0.28 \\
\hline
\end{tabular}

Note: Sample size $=5,777$. Dependent variables are shares of total assets.

${ }^{*} \mathrm{p}<0.1 ;{ }^{* *} \mathrm{p}<0.05 ;{ }^{* * *} \mathrm{p}<0.01$ 
Table 2.7: Income: Interest and Noninterest

\begin{tabular}{|c|c|c|c|c|}
\hline & \multicolumn{4}{|c|}{ Dependent Variable: } \\
\hline & $\begin{array}{l}\text { i.RE } \\
\text { (1) }\end{array}$ & $\begin{array}{l}\text { i.CI } \\
\text { (2) }\end{array}$ & $\begin{array}{l}\text { i.Cons } \\
\text { (3) }\end{array}$ & $\begin{array}{c}\text { i.OthLns } \\
\text { (4) }\end{array}$ \\
\hline WV & $\begin{array}{l}56.39^{* * *} \\
(4.13)\end{array}$ & $\begin{array}{l}3.76^{* *} \\
(1.71)\end{array}$ & $\begin{array}{l}15.75^{* * *} \\
(4.27)\end{array}$ & $\begin{array}{c}0.96 \\
(1.45)\end{array}$ \\
\hline US* & $\begin{array}{l}39.66^{* * *} \\
(1.24)\end{array}$ & $\begin{array}{l}6.37^{* * *} \\
(0.51)\end{array}$ & $\begin{array}{l}23.61^{* * *} \\
(1.28)\end{array}$ & $\begin{array}{l}2.84^{* * *} \\
(0.44)\end{array}$ \\
\hline Class: Nonmember & $\begin{array}{c}-26.01^{* * *} \\
(7.21)\end{array}$ & $\begin{array}{c}-1.77 \\
(2.98)\end{array}$ & $\begin{array}{l}10.03 \\
(7.44)\end{array}$ & $\begin{array}{c}-0.94 \\
(2.52)\end{array}$ \\
\hline Class: State Member & $\begin{array}{c}-4.05^{\text {*** }} \\
(0.61)\end{array}$ & $\begin{array}{c}-0.74^{* * *} \\
(0.25)\end{array}$ & $\begin{array}{c}-11.30^{* * *} \\
(0.63)\end{array}$ & $\begin{array}{c}-0.90^{* * *} \\
(0.21)\end{array}$ \\
\hline Class: Savings Bank & $\begin{array}{c}-5.47 \\
(7.30)\end{array}$ & $\begin{array}{c}-1.44 \\
(3.02)\end{array}$ & $\begin{array}{c}-2.59 \\
(7.53)\end{array}$ & $\begin{array}{c}-3.36 \\
(2.55)\end{array}$ \\
\hline Class: Savings Assoc. & $\begin{array}{c}-17.39^{* * *} \\
(1.43)\end{array}$ & $\begin{array}{c}-7.33^{* * *} \\
(0.59)\end{array}$ & $\begin{array}{c}1.83 \\
(1.48)\end{array}$ & $\begin{array}{c}-2.01^{* * *} \\
(0.50)\end{array}$ \\
\hline Owned: Multi-BHC & $\begin{array}{c}-20.82^{* * *} \\
(1.15)\end{array}$ & $\begin{array}{l}2.72^{* * *} \\
(0.47)\end{array}$ & $\begin{array}{l}2.75^{* *} \\
(1.18)\end{array}$ & $\begin{array}{l}3.08^{* * *} \\
(0.40)\end{array}$ \\
\hline Owned: Single-BHC & $\begin{array}{c}-1.08 \\
(1.10)\end{array}$ & $\begin{array}{l}6.42^{* * *} \\
(0.46)\end{array}$ & $\begin{array}{c}-8.15^{* * *} \\
(1.14)\end{array}$ & $\begin{array}{c}0.35 \\
(0.39)\end{array}$ \\
\hline Reg. by FDIC & $\begin{array}{l}33.58^{* * *} \\
(7.18)\end{array}$ & $\begin{array}{c}-1.59 \\
(2.97)\end{array}$ & $\begin{array}{r}-12.82^{*} \\
(7.41)\end{array}$ & $\begin{array}{c}0.06 \\
(2.51)\end{array}$ \\
\hline Age: $0-10 \mathrm{yrs}$ & $\begin{array}{l}12.47^{* * *} \\
(0.86)\end{array}$ & $\begin{array}{l}3.40^{* * *} \\
(0.35)\end{array}$ & $\begin{array}{c}-11.10^{* * *} \\
(0.88)\end{array}$ & $\begin{array}{c}-0.64^{* *} \\
(0.30)\end{array}$ \\
\hline Age: $10-20 \mathrm{yrs}$ & $\begin{array}{c}-3.64^{* * *} \\
(0.82)\end{array}$ & $\begin{array}{l}5.86^{* * *} \\
(0.34)\end{array}$ & $\begin{array}{c}-0.04 \\
(0.84)\end{array}$ & $\begin{array}{c}-2.06^{* * *} \\
(0.29)\end{array}$ \\
\hline Bank Size: Nat. Share of Deposits & $\begin{array}{c}-1.11^{* * *} \\
(0.09)\end{array}$ & $\begin{array}{c}-1.15^{* * *} \\
(0.04)\end{array}$ & $\begin{array}{l}0.57^{* * *} \\
(0.10)\end{array}$ & $\begin{array}{l}0.61^{* * *} \\
(0.03)\end{array}$ \\
\hline Market Size: Share of States & $\begin{array}{l}0.36^{* * *} \\
(0.03)\end{array}$ & $\begin{array}{l}0.07^{* * *} \\
(0.01)\end{array}$ & $\begin{array}{l}0.23^{* * *} \\
(0.03)\end{array}$ & $\begin{array}{c}-0.33^{* * *} \\
(0.01)\end{array}$ \\
\hline Market Size: Share of Pop. & $\begin{array}{c}-0.17^{* * *} \\
(0.03)\end{array}$ & $\begin{array}{l}0.07^{* * *} \\
(0.01)\end{array}$ & $\begin{array}{c}-0.42^{* * *} \\
(0.03)\end{array}$ & $\begin{array}{l}0.20^{* * *} \\
(0.01)\end{array}$ \\
\hline WV coef. for base regression: & 56 & 8.1 & 4.4 & 0.084 \\
\hline US* coef. for base regression: & 25 & 9.2 & 12 & 5.1 \\
\hline F.E. Contribution: & 0.78 & 0.85 & 0.78 & 0.67 \\
\hline F-test: $\mathrm{WV}=\mathrm{US}^{*}(\mathrm{p}$-value $)$ & 0.00 & 0.10 & 0.00 & 0.00 \\
\hline Adjusted $\mathrm{R}^{2}$ & 0.81 & 0.76 & 0.49 & 0.63 \\
\hline
\end{tabular}

Note: Sample size $=5,777$. Dependent variables are shares of total revenue.

${ }^{*} \mathrm{p}<0.1 ;{ }^{* *} \mathrm{p}<0.05 ;{ }^{* * *} \mathrm{p}<0.01$ 


\section{Income: Interest and Noninterest (continued)}

\begin{tabular}{|c|c|c|c|}
\hline & \multicolumn{3}{|c|}{ Dependent Variable: } \\
\hline & $\begin{array}{l}\text { i.Sct } \\
\text { (1) }\end{array}$ & $\begin{array}{l}\text { i.FFandOth } \\
\text { (2) }\end{array}$ & $\begin{array}{l}\text { Nonint } \\
\text { (3) }\end{array}$ \\
\hline WV & $\begin{array}{l}16.71^{* * *} \\
(2.64)\end{array}$ & $\begin{array}{c}1.25 \\
(0.88)\end{array}$ & $\begin{array}{c}3.28 \\
(3.68)\end{array}$ \\
\hline US* & $\begin{array}{l}16.94^{* * *} \\
(0.79)\end{array}$ & $\begin{array}{l}1.61^{* * *} \\
(0.26)\end{array}$ & $\begin{array}{l}6.91^{\text {*** }} \\
(1.11)\end{array}$ \\
\hline Class: Nonmember & $\begin{array}{l}11.09^{* *} \\
(4.60)\end{array}$ & $\begin{array}{c}-0.02 \\
(1.53)\end{array}$ & $\begin{array}{c}7.23 \\
(6.42)\end{array}$ \\
\hline Class: State Member & $\begin{array}{c}-0.39 \\
(0.39)\end{array}$ & $\begin{array}{l}0.96^{* * *} \\
(0.13)\end{array}$ & $\begin{array}{l}17.45^{\text {*** }} \\
(0.54)\end{array}$ \\
\hline Class: Savings Bank & $\begin{array}{l}11.32^{* *} \\
(4.66)\end{array}$ & $\begin{array}{c}-0.24 \\
(1.55)\end{array}$ & $\begin{array}{c}2.33 \\
(6.50)\end{array}$ \\
\hline Class: Savings Assoc. & $\begin{array}{l}17.36^{* * *} \\
(0.91)\end{array}$ & $\begin{array}{c}-2.53^{* * *} \\
(0.30)\end{array}$ & $\begin{array}{l}12.02^{\text {*** }} \\
(1.28)\end{array}$ \\
\hline Owned: Multi-BHC & $\begin{array}{c}-5.91^{* * *} \\
(0.73)\end{array}$ & $\begin{array}{l}2.44^{* * *} \\
(0.24)\end{array}$ & $\begin{array}{l}15.85^{\text {*** }} \\
(1.02)\end{array}$ \\
\hline Owned: Single-BHC & $\begin{array}{c}-5.33^{* * *} \\
(0.70)\end{array}$ & $\begin{array}{c}-0.20 \\
(0.23)\end{array}$ & $\begin{array}{l}7.59^{* * *} \\
(0.98)\end{array}$ \\
\hline Reg. by FDIC & $\begin{array}{c}-14.10^{* * *} \\
(4.58)\end{array}$ & $\begin{array}{c}-0.57 \\
(1.52)\end{array}$ & $\begin{array}{c}-3.50 \\
(6.39)\end{array}$ \\
\hline Age: $0-10 \mathrm{yrs}$ & $\begin{array}{c}-8.60^{* * *} \\
(0.55)\end{array}$ & $\begin{array}{l}4.01^{* * *} \\
(0.18)\end{array}$ & $\begin{array}{c}-0.66 \\
(0.76)\end{array}$ \\
\hline Age: $10-20$ yrs & $\begin{array}{l}5.03^{* * *} \\
(0.52)\end{array}$ & $\begin{array}{l}0.47^{* * *} \\
(0.17)\end{array}$ & $\begin{array}{c}-5.88^{* * *} \\
(0.73)\end{array}$ \\
\hline Bank Size: Nat. Share of Deposits & $\begin{array}{l}0.13^{* *} \\
(0.06)\end{array}$ & $\begin{array}{l}0.56^{* * *} \\
(0.02)\end{array}$ & $\begin{array}{l}0.42^{\text {***}} \\
(0.08)\end{array}$ \\
\hline Market Size: Share of States & $\begin{array}{l}0.14^{* * *} \\
(0.02)\end{array}$ & $\begin{array}{c}-0.21^{* * *} \\
(0.01)\end{array}$ & $\begin{array}{c}-0.28^{* * *} \\
(0.03)\end{array}$ \\
\hline Market Size: Share of Pop. & $\begin{array}{c}-0.12^{* * *} \\
(0.02)\end{array}$ & $\begin{array}{l}0.12^{* * *} \\
(0.01)\end{array}$ & $\begin{array}{l}0.36^{* * *} \\
(0.03)\end{array}$ \\
\hline WV coef. for base regression: & 10 & 1.1 & 19 \\
\hline US* coef. for base regression: & 12 & 4.7 & 31 \\
\hline F.E. Contribution: & 0.85 & 0.72 & 0.91 \\
\hline F-test: WV $=$ US* (p-value $)$ & 0.92 & 0.56 & 0.44 \\
\hline Adjusted $\mathrm{R}^{2}$ & 0.67 & 0.78 & 0.88 \\
\hline
\end{tabular}

Note: Sample size $=5,777$. Dependent variables are shares of total revenue. ${ }^{*} \mathrm{p}<0.1 ;{ }^{* *} \mathrm{p}<0.05 ;{ }^{* * *} \mathrm{p}<0.01$ 
Table 2.8: Noninterest Income

\begin{tabular}{|c|c|c|c|c|}
\hline & \multicolumn{4}{|c|}{ Dependent Variable: } \\
\hline & $\begin{array}{c}\text { FiducAcvt } \\
\text { (1) }\end{array}$ & $\begin{array}{c}\text { DepAcctsChg } \\
\text { (2) }\end{array}$ & $\begin{array}{c}\text { Trad } \\
(3)\end{array}$ & $\begin{array}{c}\text { Invest } \\
(4)\end{array}$ \\
\hline WV & $\begin{array}{c}-1.26 \\
(2.62)\end{array}$ & $\begin{array}{l}4.84^{* * *} \\
(0.88)\end{array}$ & $\begin{array}{c}-0.01 \\
(0.59)\end{array}$ & $\begin{array}{c}-1.27 \\
(0.80)\end{array}$ \\
\hline US* & $\begin{array}{c}-0.91 \\
(0.79)\end{array}$ & $\begin{array}{l}3.42^{* * *} \\
(0.27)\end{array}$ & $\begin{array}{c}-0.04 \\
(0.18)\end{array}$ & $\begin{array}{c}-0.37 \\
(0.24)\end{array}$ \\
\hline Class: Nonmember & $\begin{array}{c}4.23 \\
(4.57)\end{array}$ & $\begin{array}{c}-0.76 \\
(1.54)\end{array}$ & $\begin{array}{c}-0.16 \\
(1.03)\end{array}$ & $\begin{array}{l}3.33^{* *} \\
(1.39)\end{array}$ \\
\hline Class: State Member & $\begin{array}{l}14.28^{* * *} \\
(0.39)\end{array}$ & $\begin{array}{l}0.73^{* * *} \\
(0.13)\end{array}$ & $\begin{array}{l}1.41^{* * *} \\
(0.09)\end{array}$ & $\begin{array}{l}1.08^{* * *} \\
(0.12)\end{array}$ \\
\hline Class: Savings Bank & $\begin{array}{c}2.32 \\
(4.62)\end{array}$ & $\begin{array}{c}-0.84 \\
(1.56)\end{array}$ & $\begin{array}{c}-0.91 \\
(1.05)\end{array}$ & $\begin{array}{c}2.13 \\
(1.41)\end{array}$ \\
\hline Class: Savings Assoc. & $\begin{array}{l}6.73^{* * *} \\
(0.91)\end{array}$ & $\begin{array}{r}-0.59^{*} \\
(0.31)\end{array}$ & $\begin{array}{c}-1.09^{* * *} \\
(0.21)\end{array}$ & $\begin{array}{c}-1.12^{* * *} \\
(0.28)\end{array}$ \\
\hline Owned: Multi-BHC & $\begin{array}{l}5.28^{* * *} \\
(0.73)\end{array}$ & $\begin{array}{c}-0.24 \\
(0.24)\end{array}$ & $\begin{array}{l}2.12^{* * *} \\
(0.16)\end{array}$ & $\begin{array}{l}0.45^{* *} \\
(0.22)\end{array}$ \\
\hline Owned: Single-BHC & $\begin{array}{c}-3.07^{* * *} \\
(0.70)\end{array}$ & $\begin{array}{l}1.22^{* * *} \\
(0.23)\end{array}$ & $\begin{array}{c}0.16 \\
(0.16)\end{array}$ & $\begin{array}{l}0.55^{* * *} \\
(0.21)\end{array}$ \\
\hline Reg. by FDIC & $\begin{array}{c}-0.61 \\
(4.55)\end{array}$ & $\begin{array}{c}0.17 \\
(1.53)\end{array}$ & $\begin{array}{c}0.24 \\
(1.03)\end{array}$ & $\begin{array}{c}-1.13 \\
(1.39)\end{array}$ \\
\hline Age: $0-10 \mathrm{yrs}$ & $\begin{array}{c}-5.39^{* * *} \\
(0.54)\end{array}$ & $\begin{array}{c}-2.03^{* * *} \\
(0.18)\end{array}$ & $\begin{array}{l}1.08^{* * *} \\
(0.12)\end{array}$ & $\begin{array}{l}2.53^{* * *} \\
(0.17)\end{array}$ \\
\hline Age: $10-20 \mathrm{yrs}$ & $\begin{array}{c}-3.90^{* * *} \\
(0.52)\end{array}$ & $\begin{array}{c}-1.56^{* * *} \\
(0.17)\end{array}$ & $\begin{array}{c}-0.42^{* * *} \\
(0.12)\end{array}$ & $\begin{array}{c}-0.55^{* * *} \\
(0.16)\end{array}$ \\
\hline Bank Size: Nat. Share of Deposits & $\begin{array}{c}-0.37^{* * *} \\
(0.06)\end{array}$ & $\begin{array}{c}-0.21^{* * *} \\
(0.02)\end{array}$ & $\begin{array}{l}1.00^{* * *} \\
(0.01)\end{array}$ & $\begin{array}{l}0.06^{* * *} \\
(0.02)\end{array}$ \\
\hline Market Size: Share of States & $\begin{array}{c}-0.21^{* * *} \\
(0.02)\end{array}$ & $\begin{array}{l}0.16^{* * *} \\
(0.01)\end{array}$ & $\begin{array}{c}-0.35^{* * *} \\
(0.004)\end{array}$ & $\begin{array}{c}-0.15^{* * *} \\
(0.01)\end{array}$ \\
\hline Market Size: Share of Pop. & $\begin{array}{l}0.20^{* * *} \\
(0.02)\end{array}$ & $\begin{array}{c}-0.05^{* * *} \\
(0.01)\end{array}$ & $\begin{array}{c}0.20^{* * *} \\
(0.005)\end{array}$ & $\begin{array}{l}0.14^{* * *} \\
(0.01)\end{array}$ \\
\hline WV coef. for base regression: & 2.8 & 5.9 & 0.036 & 0.81 \\
\hline US* coef. for base regression: & 4.5 & 4.9 & 3.7 & 2.3 \\
\hline F.E. Contribution: & 0.4 & 0.85 & 0.45 & 0.73 \\
\hline F-test: WV = US* (p-value) & 0.92 & 0.15 & 0.96 & 0.22 \\
\hline Adjusted $\mathrm{R}^{2}$ & 0.40 & 0.77 & 0.89 & 0.50 \\
\hline
\end{tabular}

Note: Sample size $=5,777$. Dependent variables are shares of total revenue.

${ }^{*} \mathrm{p}<0.1 ;{ }^{* *} \mathrm{p}<0.05 ;{ }^{* * *} \mathrm{p}<0.01$ 


\section{Noninterest Income (continued)}

\begin{tabular}{|c|c|c|c|c|}
\hline & \multicolumn{4}{|c|}{ Dependent Variable: } \\
\hline & $\begin{array}{c}\text { ServFees } \\
\text { (1) }\end{array}$ & $\begin{array}{l}\text { Securiz } \\
\text { (2) }\end{array}$ & $\begin{array}{c}\text { SalesAssets } \\
\text { (3) }\end{array}$ & $\begin{array}{c}\text { OthNonii } \\
\text { (4) }\end{array}$ \\
\hline WV & $\begin{array}{c}0.16 \\
(0.50)\end{array}$ & $\begin{array}{c}-0.45^{* * *} \\
(0.16)\end{array}$ & $\begin{array}{c}1.98^{*} \\
(1.19)\end{array}$ & $\begin{array}{c}-0.70 \\
(2.17)\end{array}$ \\
\hline US* & $\begin{array}{l}1.24^{* * *} \\
(0.15)\end{array}$ & $\begin{array}{c}-0.32^{* * *} \\
(0.05)\end{array}$ & $\begin{array}{l}2.50^{* * *} \\
(0.36)\end{array}$ & $\begin{array}{l}1.40^{* *} \\
(0.65)\end{array}$ \\
\hline Class: Nonmember & $\begin{array}{c}0.44 \\
(0.88)\end{array}$ & $\begin{array}{c}0.43 \\
(0.28)\end{array}$ & $\begin{array}{c}-7.22^{* * *} \\
(2.08)\end{array}$ & $\begin{array}{c}6.93^{*} \\
(3.78)\end{array}$ \\
\hline Class: State Member & $\begin{array}{c}-0.20^{* * *} \\
(0.07)\end{array}$ & $\begin{array}{c}0.03 \\
(0.02)\end{array}$ & $\begin{array}{c}-1.00^{* * *} \\
(0.18)\end{array}$ & $\begin{array}{l}1.12^{* * *} \\
(0.32)\end{array}$ \\
\hline Class: Savings Bank & $\begin{array}{c}0.16 \\
(0.89)\end{array}$ & $\begin{array}{c}0.29 \\
(0.28)\end{array}$ & $\begin{array}{c}-7.03^{* * *} \\
(2.11)\end{array}$ & $\begin{array}{c}6.21 \\
(3.83)\end{array}$ \\
\hline Class: Savings Assoc. & $\begin{array}{c}-0.26 \\
(0.17)\end{array}$ & $\begin{array}{l}0.46^{* * *} \\
(0.06)\end{array}$ & $\begin{array}{c}0.47 \\
(0.41)\end{array}$ & $\begin{array}{l}7.41^{* * *} \\
(0.75)\end{array}$ \\
\hline Owned: Multi-BHC & $\begin{array}{c}-0.28^{* *} \\
(0.14)\end{array}$ & $\begin{array}{l}0.44^{* * *} \\
(0.04)\end{array}$ & $\begin{array}{c}-0.92^{* * *} \\
(0.33)\end{array}$ & $\begin{array}{l}9.01^{* * *} \\
(0.60)\end{array}$ \\
\hline Owned: Single-BHC & $\begin{array}{l}0.32^{* *} \\
(0.13)\end{array}$ & $\begin{array}{l}0.26^{* * *} \\
(0.04)\end{array}$ & $\begin{array}{l}0.82^{* * *} \\
(0.32)\end{array}$ & $\begin{array}{l}7.33^{* * *} \\
(0.58)\end{array}$ \\
\hline Reg. by FDIC & $\begin{array}{c}-0.90 \\
(0.88)\end{array}$ & $\begin{array}{c}-0.16 \\
(0.28)\end{array}$ & $\begin{array}{l}6.91^{* * *} \\
(2.07)\end{array}$ & $\begin{array}{c}-8.02^{* *} \\
(3.76)\end{array}$ \\
\hline Age: $0-10$ yrs & $\begin{array}{c}0.02 \\
(0.10)\end{array}$ & $\begin{array}{c}0.03 \\
(0.03)\end{array}$ & $\begin{array}{l}0.78^{* * *} \\
(0.25)\end{array}$ & $\begin{array}{l}2.31^{* * *} \\
(0.45)\end{array}$ \\
\hline Age: $10-20$ yrs & $\begin{array}{c}0.18^{*} \\
(0.10)\end{array}$ & $\begin{array}{c}-0.07^{* *} \\
(0.03)\end{array}$ & $\begin{array}{c}0.36 \\
(0.24)\end{array}$ & $\begin{array}{c}0.08 \\
(0.43)\end{array}$ \\
\hline Bank Size: Nat. Share of Deposits & $\begin{array}{l}0.07^{* * *} \\
(0.01)\end{array}$ & $\begin{array}{c}0.01^{* *} \\
(0.004)\end{array}$ & $\begin{array}{c}-0.15^{* * *} \\
(0.03)\end{array}$ & $\begin{array}{c}0.02 \\
(0.05)\end{array}$ \\
\hline Market Size: Share of States & $\begin{array}{c}0.02^{* * *} \\
(0.004)\end{array}$ & $\begin{array}{c}0.01^{* * *} \\
(0.001)\end{array}$ & $\begin{array}{l}0.04^{* * *} \\
(0.01)\end{array}$ & $\begin{array}{l}0.21^{* * *} \\
(0.02)\end{array}$ \\
\hline Market Size: Share of Pop. & $\begin{array}{r}-0.01^{* *} \\
(0.004)\end{array}$ & $\begin{array}{c}-0.01^{\text {*** }} \\
(0.001)\end{array}$ & $\begin{array}{c}-0.03^{* * *} \\
(0.01)\end{array}$ & $\begin{array}{c}-0.08^{* * *} \\
(0.02)\end{array}$ \\
\hline WV coef. for base regression: & 0.052 & 0 & 2.1 & 7.2 \\
\hline US* coef. for base regression: & 1.4 & 0.064 & 1.5 & 13 \\
\hline F.E. Contribution: & 0.91 & 0.27 & 0.63 & 0.91 \\
\hline F-test: WV = US* (p-value) & 0.00 & 0.21 & 0.76 & 0.10 \\
\hline Adjusted $\mathrm{R}^{2}$ & 0.44 & 0.05 & 0.19 & 0.78 \\
\hline
\end{tabular}


Table 2.9: Expenses: Interest and Noninterest

\begin{tabular}{|c|c|c|c|c|c|}
\hline & \multicolumn{5}{|c|}{ Dependent Variable: } \\
\hline & $\begin{array}{c}\text { i.ExpDep } \\
\text { (1) }\end{array}$ & $\begin{array}{l}\text { i.ExpOth } \\
\text { (2) }\end{array}$ & $\begin{array}{c}\text { nonint.Sal } \\
\text { (3) }\end{array}$ & $\begin{array}{c}\text { nonint.As } \\
\text { (4) }\end{array}$ & $\begin{array}{l}\text { nonint.Oth } \\
\text { (5) }\end{array}$ \\
\hline $\mathrm{WV}$ & $\begin{array}{l}12.49^{* * *} \\
(1.60)\end{array}$ & $\begin{array}{l}5.23^{* * *} \\
(1.25)\end{array}$ & $\begin{array}{l}41.50^{* * *} \\
(2.93)\end{array}$ & $\begin{array}{l}10.43^{* * *} \\
(1.15)\end{array}$ & $\begin{array}{l}30.35^{* * *} \\
(3.26)\end{array}$ \\
\hline US* & $\begin{array}{l}11.35^{* * *} \\
(0.48)\end{array}$ & $\begin{array}{l}4.46^{* * *} \\
(0.38)\end{array}$ & $\begin{array}{l}42.94^{* * *} \\
(0.88)\end{array}$ & $\begin{array}{l}8.58^{* * *} \\
(0.35)\end{array}$ & $\begin{array}{l}32.66^{\text {*** }} \\
(0.98)\end{array}$ \\
\hline Class: Nonmember & $\begin{array}{c}-4.27 \\
(2.79)\end{array}$ & $\begin{array}{c}-1.23 \\
(2.18)\end{array}$ & $\begin{array}{c}-15.14^{* * *} \\
(5.11)\end{array}$ & $\begin{array}{c}-4.56^{* *} \\
(2.01)\end{array}$ & $\begin{array}{l}25.20^{\text {*** }} \\
(5.68)\end{array}$ \\
\hline Class: State Member & $\begin{array}{c}-0.55^{* *} \\
(0.24)\end{array}$ & $\begin{array}{c}-2.33^{* * *} \\
(0.18)\end{array}$ & $\begin{array}{l}5.33^{* * *} \\
(0.43)\end{array}$ & $\begin{array}{l}1.30^{* * *} \\
(0.17)\end{array}$ & $\begin{array}{c}-3.75^{* * *} \\
(0.48)\end{array}$ \\
\hline Class: Savings Bank & $\begin{array}{c}0.67 \\
(2.82)\end{array}$ & $\begin{array}{c}1.68 \\
(2.21)\end{array}$ & $\begin{array}{c}-16.63^{* * *} \\
(5.17)\end{array}$ & $\begin{array}{c}-3.77^{*} \\
(2.03)\end{array}$ & $\begin{array}{l}18.04^{\text {*** }} \\
(5.75)\end{array}$ \\
\hline Class: Savings Assoc. & $\begin{array}{c}-3.94^{* * *} \\
(0.55)\end{array}$ & $\begin{array}{c}-2.99^{* * *} \\
(0.43)\end{array}$ & $\begin{array}{c}-9.25^{* * *} \\
(1.02)\end{array}$ & $\begin{array}{c}-3.28^{* * *} \\
(0.40)\end{array}$ & $\begin{array}{l}19.47^{* * *} \\
(1.13)\end{array}$ \\
\hline Owned: Multi-BHC & $\begin{array}{c}-2.87^{* * *} \\
(0.44)\end{array}$ & $\begin{array}{l}2.34^{* * *} \\
(0.35)\end{array}$ & $\begin{array}{c}-10.97^{* * *} \\
(0.81)\end{array}$ & $\begin{array}{c}-1.61^{* * *} \\
(0.32)\end{array}$ & $\begin{array}{l}13.11^{\text {*** }} \\
(0.90)\end{array}$ \\
\hline Owned: Single-BHC & $\begin{array}{c}-2.31^{* * *} \\
(0.43)\end{array}$ & $\begin{array}{c}-0.80^{* *} \\
(0.33)\end{array}$ & $\begin{array}{c}0.08 \\
(0.78)\end{array}$ & $\begin{array}{l}1.14^{* * *} \\
(0.31)\end{array}$ & $\begin{array}{l}1.88^{* *} \\
(0.87)\end{array}$ \\
\hline Reg. by FDIC & $\begin{array}{r}4.72^{*} \\
(2.78)\end{array}$ & $\begin{array}{c}-0.26 \\
(2.17)\end{array}$ & $\begin{array}{l}19.25^{* * *} \\
(5.09)\end{array}$ & $\begin{array}{l}5.17^{* * *} \\
(2.00)\end{array}$ & $\begin{array}{c}-28.88^{* * *} \\
(5.66)\end{array}$ \\
\hline Age: $0-10$ yrs & $\begin{array}{l}6.93^{* * *} \\
(0.33)\end{array}$ & $\begin{array}{l}3.06^{* * *} \\
(0.26)\end{array}$ & $\begin{array}{c}-8.15^{* * *} \\
(0.61)\end{array}$ & $\begin{array}{c}-1.33^{* * *} \\
(0.24)\end{array}$ & $\begin{array}{c}-0.50 \\
(0.68)\end{array}$ \\
\hline Age: $10-20$ yrs & $\begin{array}{l}4.84^{* * *} \\
(0.32)\end{array}$ & $\begin{array}{l}0.70^{* * *} \\
(0.25)\end{array}$ & $\begin{array}{c}-10.86^{* * *} \\
(0.58)\end{array}$ & $\begin{array}{c}-2.67^{* * *} \\
(0.23)\end{array}$ & $\begin{array}{l}8.01^{* * *} \\
(0.64)\end{array}$ \\
\hline Bank Size: Nat. Share of Deposits & $\begin{array}{c}-0.21^{* * *} \\
(0.04)\end{array}$ & $\begin{array}{l}0.14^{* * *} \\
(0.03)\end{array}$ & $\begin{array}{c}-0.72^{* * *} \\
(0.07)\end{array}$ & $\begin{array}{l}0.27^{* * *} \\
(0.03)\end{array}$ & $\begin{array}{l}0.51^{\text {**** }} \\
(0.07)\end{array}$ \\
\hline Market Size: Share of States & $\begin{array}{l}0.06^{* * *} \\
(0.01)\end{array}$ & $\begin{array}{c}-0.28^{* * *} \\
(0.01)\end{array}$ & $\begin{array}{l}0.23^{* * *} \\
(0.02)\end{array}$ & $\begin{array}{l}0.04^{* * *} \\
(0.01)\end{array}$ & $\begin{array}{c}-0.04 \\
(0.02)\end{array}$ \\
\hline Market Size: Share of Pop. & $\begin{array}{c}-0.09^{* * *} \\
(0.01)\end{array}$ & $\begin{array}{l}0.20^{* * *} \\
(0.01)\end{array}$ & $\begin{array}{l}0.09^{* * *} \\
(0.02)\end{array}$ & $\begin{array}{c}-0.01 \\
(0.01)\end{array}$ & $\begin{array}{c}-0.19^{* * *} \\
(0.02)\end{array}$ \\
\hline WV coef. for base regression: & 11 & 3.3 & 43 & 11 & 31 \\
\hline US* coef. for base regression: & 6.8 & 5.8 & 43 & 9.8 & 35 \\
\hline F.E. Contribution: & 0.75 & 0.83 & 0.97 & 0.96 & 0.96 \\
\hline F-test: WV = US* (p-value) & 0.37 & 0.52 & 0.48 & 0.02 & 0.22 \\
\hline Adjusted $\mathrm{R}^{2}$ & 0.69 & 0.70 & 0.95 & 0.87 & 0.92 \\
\hline
\end{tabular}


Table 2.10: Interest Expenses

\begin{tabular}{|c|c|c|c|c|c|c|}
\hline & \multicolumn{6}{|c|}{ Dependent Variable: } \\
\hline & $\begin{array}{c}\text { TrAcct } \\
(1)\end{array}$ & $\begin{array}{c}\text { SavAcct } \\
\text { (2) }\end{array}$ & $\begin{array}{c}\text { TmDep } \\
\text { (3) }\end{array}$ & $\begin{array}{c}\text { efrepp } \\
(4)\end{array}$ & $\begin{array}{c}\text { USTrea } \\
(5)\end{array}$ & $\begin{array}{c}\text { i.ExpOth } \\
(6)\end{array}$ \\
\hline $\mathrm{WV}$ & $\begin{array}{l}1.65^{* * *} \\
(0.18)\end{array}$ & $\begin{array}{l}2.28^{* *} \\
(0.99)\end{array}$ & $\begin{array}{l}8.57^{* * *} \\
(1.14)\end{array}$ & $\begin{array}{l}1.05^{* * *} \\
(0.24)\end{array}$ & $\begin{array}{l}2.41^{* * *} \\
(0.81)\end{array}$ & $\begin{array}{l}1.76^{* * *} \\
(0.65)\end{array}$ \\
\hline US* & $\begin{array}{l}0.86^{* * *} \\
(0.05)\end{array}$ & $\begin{array}{l}3.71^{* * *} \\
(0.30)\end{array}$ & $\begin{array}{l}6.78^{* * *} \\
(0.34)\end{array}$ & $\begin{array}{l}0.22^{* * *} \\
(0.07)\end{array}$ & $\begin{array}{l}2.69^{* * *} \\
(0.24)\end{array}$ & $\begin{array}{l}1.54^{* * *} \\
(0.20)\end{array}$ \\
\hline Class: Nonmember & $\begin{array}{c}-0.90^{* * *} \\
(0.31)\end{array}$ & $\begin{array}{r}3.19^{*} \\
(1.72)\end{array}$ & $\begin{array}{c}-6.56^{* * *} \\
(2.00)\end{array}$ & $\begin{array}{c}0.68 \\
(0.42)\end{array}$ & $\begin{array}{c}-0.04 \\
(1.41)\end{array}$ & $\begin{array}{c}-1.87 \\
(1.14)\end{array}$ \\
\hline Class: State Member & $\begin{array}{c}-0.08^{* * *} \\
(0.03)\end{array}$ & $\begin{array}{c}-0.77^{\text {*** }} \\
(0.15)\end{array}$ & $\begin{array}{c}0.30^{*} \\
(0.17)\end{array}$ & $\begin{array}{c}-0.04 \\
(0.04)\end{array}$ & $\begin{array}{c}-0.93^{* * *} \\
(0.12)\end{array}$ & $\begin{array}{c}-1.36^{* * *} \\
(0.10)\end{array}$ \\
\hline Class: Savings Bank & $\begin{array}{c}-0.98^{* * *} \\
(0.31)\end{array}$ & $\begin{array}{l}5.66^{* * *} \\
(1.74)\end{array}$ & $\begin{array}{c}-4.00^{* *} \\
(2.02)\end{array}$ & $\begin{array}{l}0.87^{* *} \\
(0.43)\end{array}$ & $\begin{array}{l}3.10^{* *} \\
(1.43)\end{array}$ & $\begin{array}{c}-2.29^{* *} \\
(1.15)\end{array}$ \\
\hline Class: Savings Assoc. & $\begin{array}{l}0.20^{* * *} \\
(0.06)\end{array}$ & $\begin{array}{c}-0.30 \\
(0.34)\end{array}$ & $\begin{array}{c}-3.84^{* * *} \\
(0.40)\end{array}$ & $\begin{array}{c}-0.19^{* *} \\
(0.08)\end{array}$ & $\begin{array}{c}-1.49^{* * *} \\
(0.28)\end{array}$ & $\begin{array}{c}-1.31^{* * *} \\
(0.23)\end{array}$ \\
\hline Owned: Multi-BHC & $\begin{array}{c}-0.28^{* * *} \\
(0.05)\end{array}$ & $\begin{array}{c}0.48^{*} \\
(0.27)\end{array}$ & $\begin{array}{c}-3.08^{* * *} \\
(0.32)\end{array}$ & $\begin{array}{l}0.17^{* * *} \\
(0.07)\end{array}$ & $\begin{array}{l}1.16^{* * *} \\
(0.22)\end{array}$ & $\begin{array}{l}1.01^{* * *} \\
(0.18)\end{array}$ \\
\hline Owned: Single-BHC & $\begin{array}{c}-0.20^{* * *} \\
(0.05)\end{array}$ & $\begin{array}{c}0.11 \\
(0.26)\end{array}$ & $\begin{array}{c}-2.22^{* * *} \\
(0.30)\end{array}$ & $\begin{array}{c}0.01 \\
(0.06)\end{array}$ & $\begin{array}{c}-0.20 \\
(0.22)\end{array}$ & $\begin{array}{c}-0.60^{* * *} \\
(0.17)\end{array}$ \\
\hline Reg. by FDIC & $\begin{array}{l}0.81^{* * *} \\
(0.31)\end{array}$ & $\begin{array}{c}-3.88^{* *} \\
(1.71)\end{array}$ & $\begin{array}{l}7.79^{* * *} \\
(1.99)\end{array}$ & $\begin{array}{c}-0.67 \\
(0.42)\end{array}$ & $\begin{array}{c}-0.41 \\
(1.41)\end{array}$ & $\begin{array}{c}0.82 \\
(1.13)\end{array}$ \\
\hline Age: $0-10 \mathrm{yrs}$ & $\begin{array}{c}-0.28^{* * *} \\
(0.04)\end{array}$ & $\begin{array}{l}3.01^{* * *} \\
(0.20)\end{array}$ & $\begin{array}{l}4.20^{* * *} \\
(0.24)\end{array}$ & $\begin{array}{l}0.65^{* * *} \\
(0.05)\end{array}$ & $\begin{array}{l}2.97^{* * *} \\
(0.17)\end{array}$ & $\begin{array}{c}-0.56^{* * *} \\
(0.14)\end{array}$ \\
\hline Age: $10-20 \mathrm{yrs}$ & $\begin{array}{l}0.39^{* * *} \\
(0.04)\end{array}$ & $\begin{array}{l}3.67^{* * *} \\
(0.19)\end{array}$ & $\begin{array}{l}0.78^{* * *} \\
(0.23)\end{array}$ & $\begin{array}{c}-0.04 \\
(0.05)\end{array}$ & $\begin{array}{l}0.60^{* * *} \\
(0.16)\end{array}$ & $\begin{array}{c}0.14 \\
(0.13)\end{array}$ \\
\hline Bank Size: Nat. Share of Deposits & $\begin{array}{c}0.12^{* * *} \\
(0.004)\end{array}$ & $\begin{array}{c}-0.32^{* * *} \\
(0.02)\end{array}$ & $\begin{array}{c}-0.01 \\
(0.03)\end{array}$ & $\begin{array}{l}0.02^{* * *} \\
(0.01)\end{array}$ & $\begin{array}{l}0.13^{* * *} \\
(0.02)\end{array}$ & $\begin{array}{c}-0.01 \\
(0.01)\end{array}$ \\
\hline Market Size: Share of States & $\begin{array}{c}-0.03^{* * *} \\
(0.001)\end{array}$ & $\begin{array}{l}0.05^{* * *} \\
(0.01)\end{array}$ & $\begin{array}{l}0.05^{* * *} \\
(0.01)\end{array}$ & $\begin{array}{c}-0.02^{* * *} \\
(0.002)\end{array}$ & $\begin{array}{c}-0.08^{* * *} \\
(0.01)\end{array}$ & $\begin{array}{c}-0.18^{* * *} \\
(0.005)\end{array}$ \\
\hline Market Size: Share of Pop. & $\begin{array}{c}0.01^{* * *} \\
(0.001)\end{array}$ & $\begin{array}{c}-0.03^{* * *} \\
(0.01)\end{array}$ & $\begin{array}{c}-0.07^{* * *} \\
(0.01)\end{array}$ & $\begin{array}{c}0.01^{* * *} \\
(0.002)\end{array}$ & $\begin{array}{l}0.05^{* * *} \\
(0.01)\end{array}$ & $\begin{array}{c}0.14^{* * *} \\
(0.005)\end{array}$ \\
\hline WV coef. for base regression: & 1.3 & 2.3 & 7 & 1.1 & 1.9 & 0.31 \\
\hline US* coef. for base regression: & 0.67 & 3 & 3.2 & 0.38 & 3.6 & 1.7 \\
\hline F.E. Contribution: & 0.74 & 0.71 & 0.65 & 0.77 & 0.9 & 0.57 \\
\hline F-test: WV = US* (p-value) & 0.01 & 0.01 & 0.16 & 0.08 & 0.79 & 0.55 \\
\hline Adjusted $\mathrm{R}^{2}$ & 0.64 & 0.54 & 0.52 & 0.23 & 0.67 & 0.53 \\
\hline
\end{tabular}


Figure 2.13: Share of Real Estate Loans by State of Bank HQ, 2017

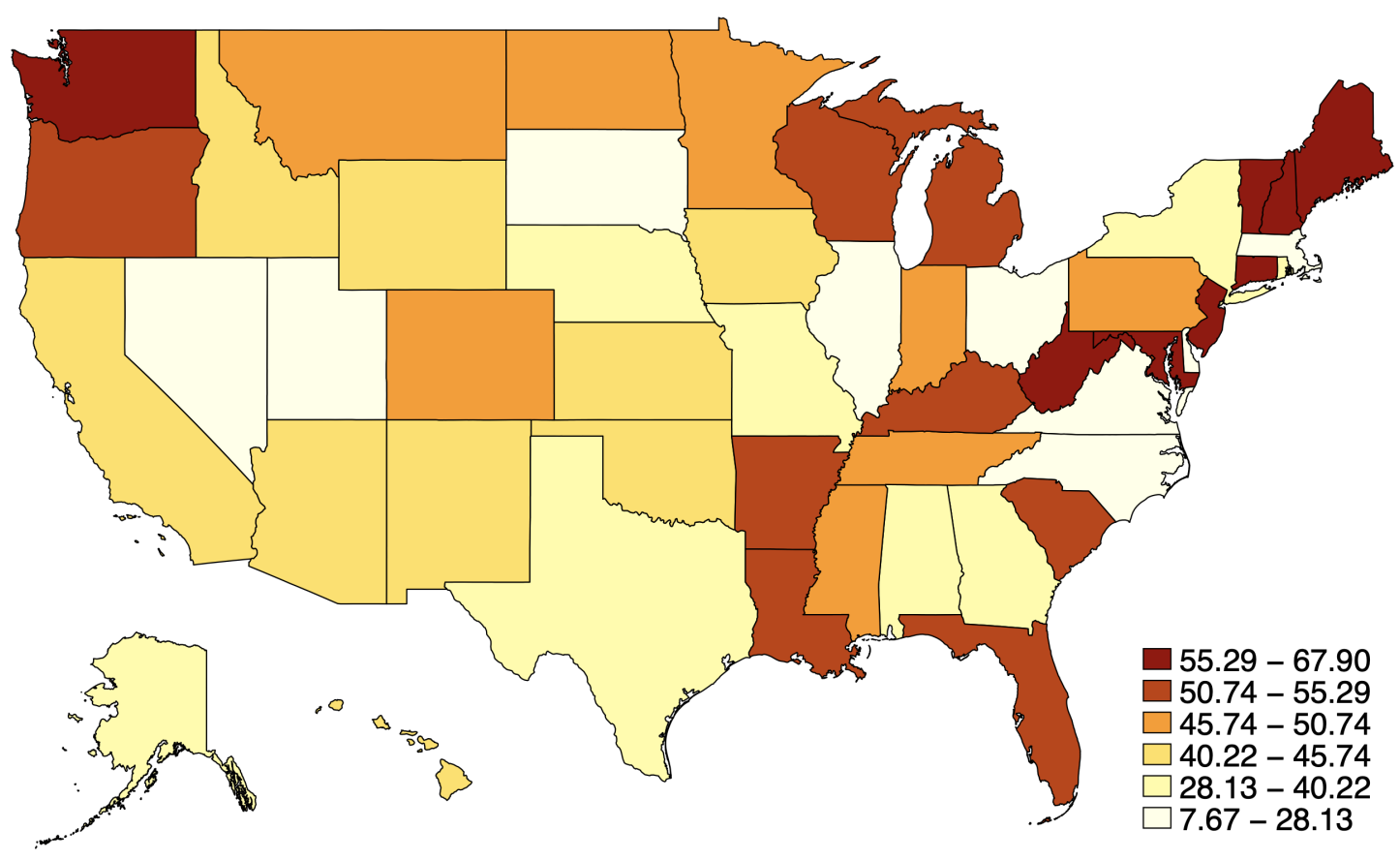


Figure 2.14: Mixed-effects Model Estimates of Real Estate Loan Shares, 2017
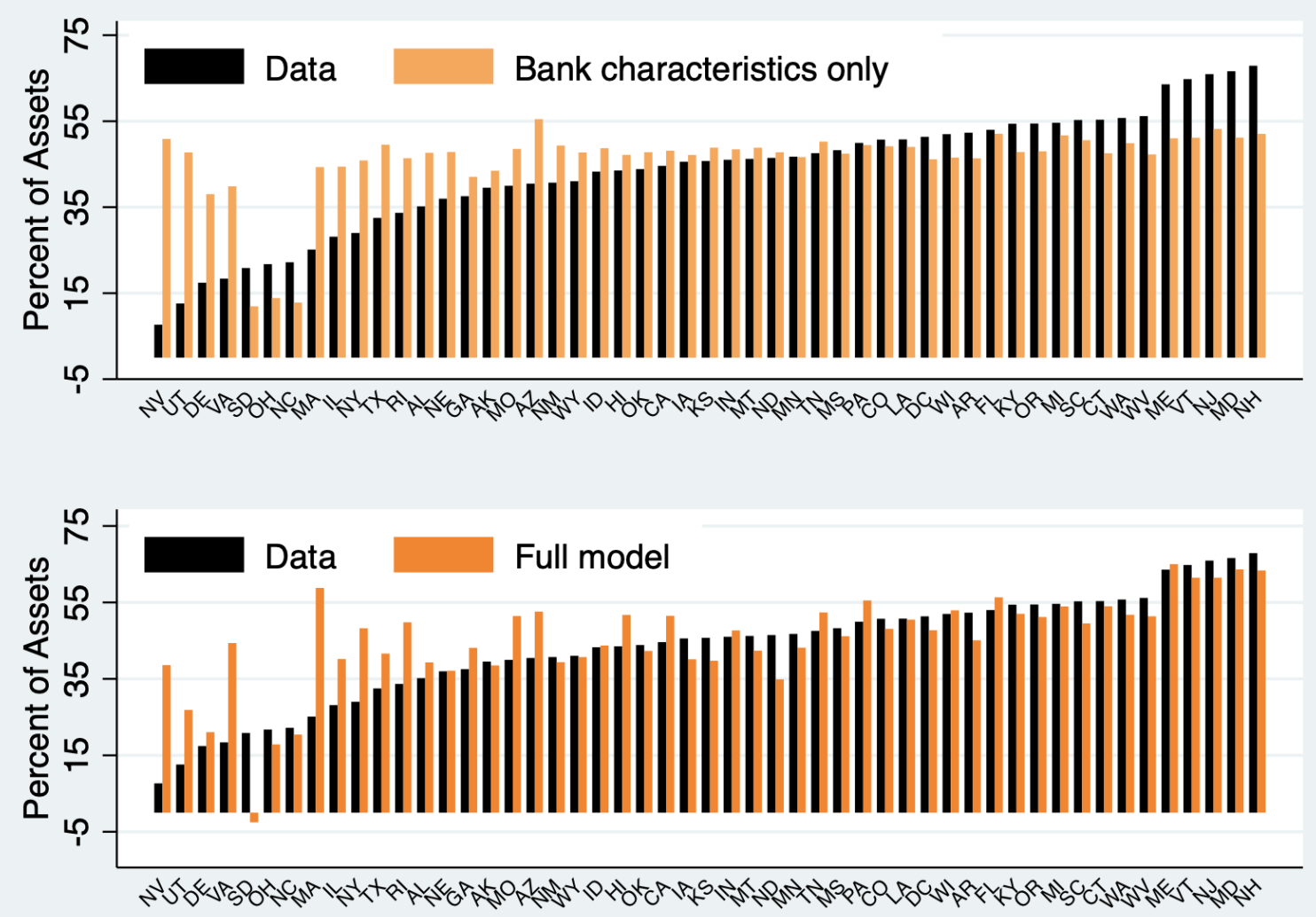
Figure 2.15: Model Errors in Real Estate Loan Shares, 2017

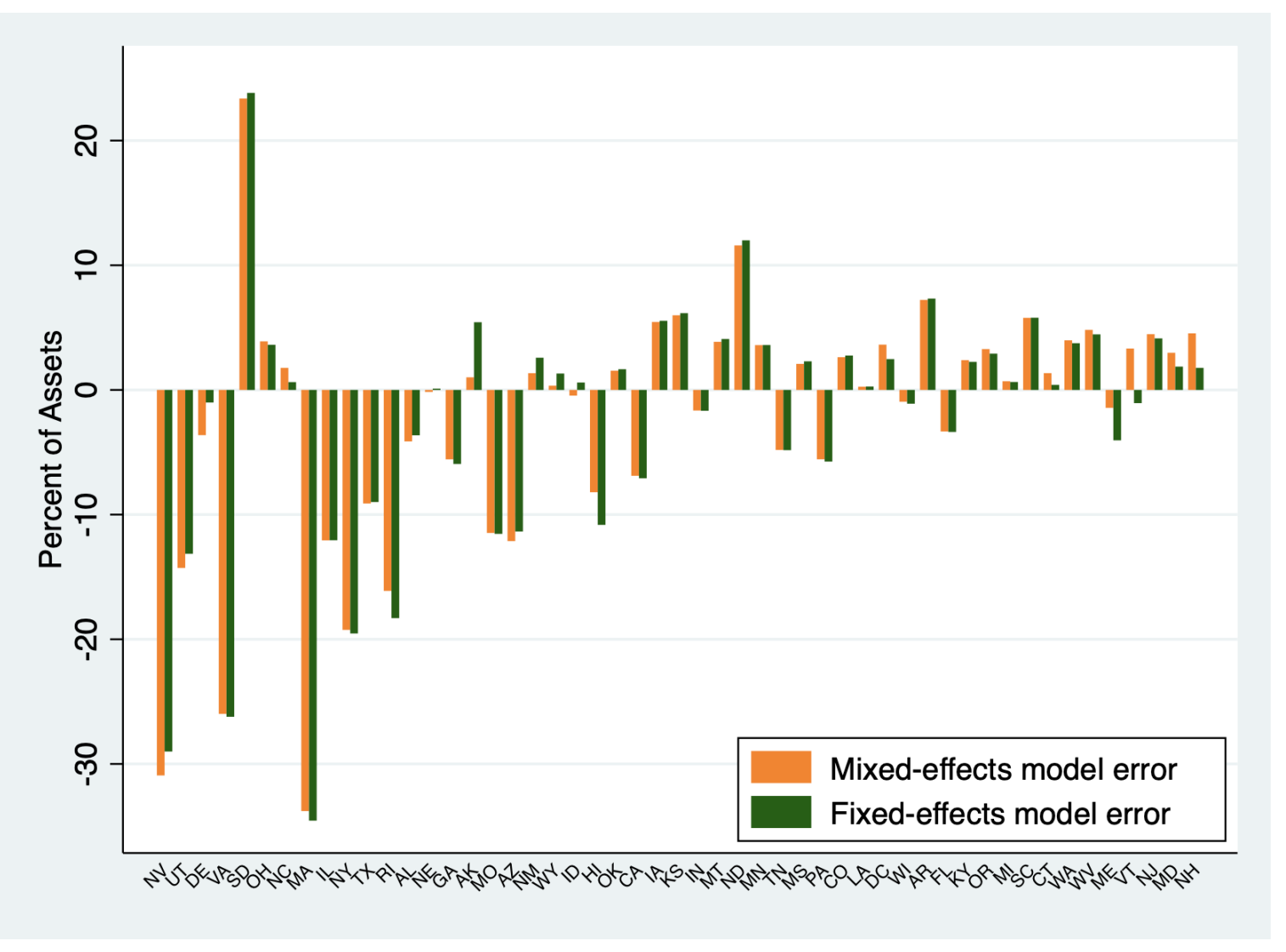


Figure 2.16: Estimated Fixed- and Random-Effects for Real Estate Loans, 2017

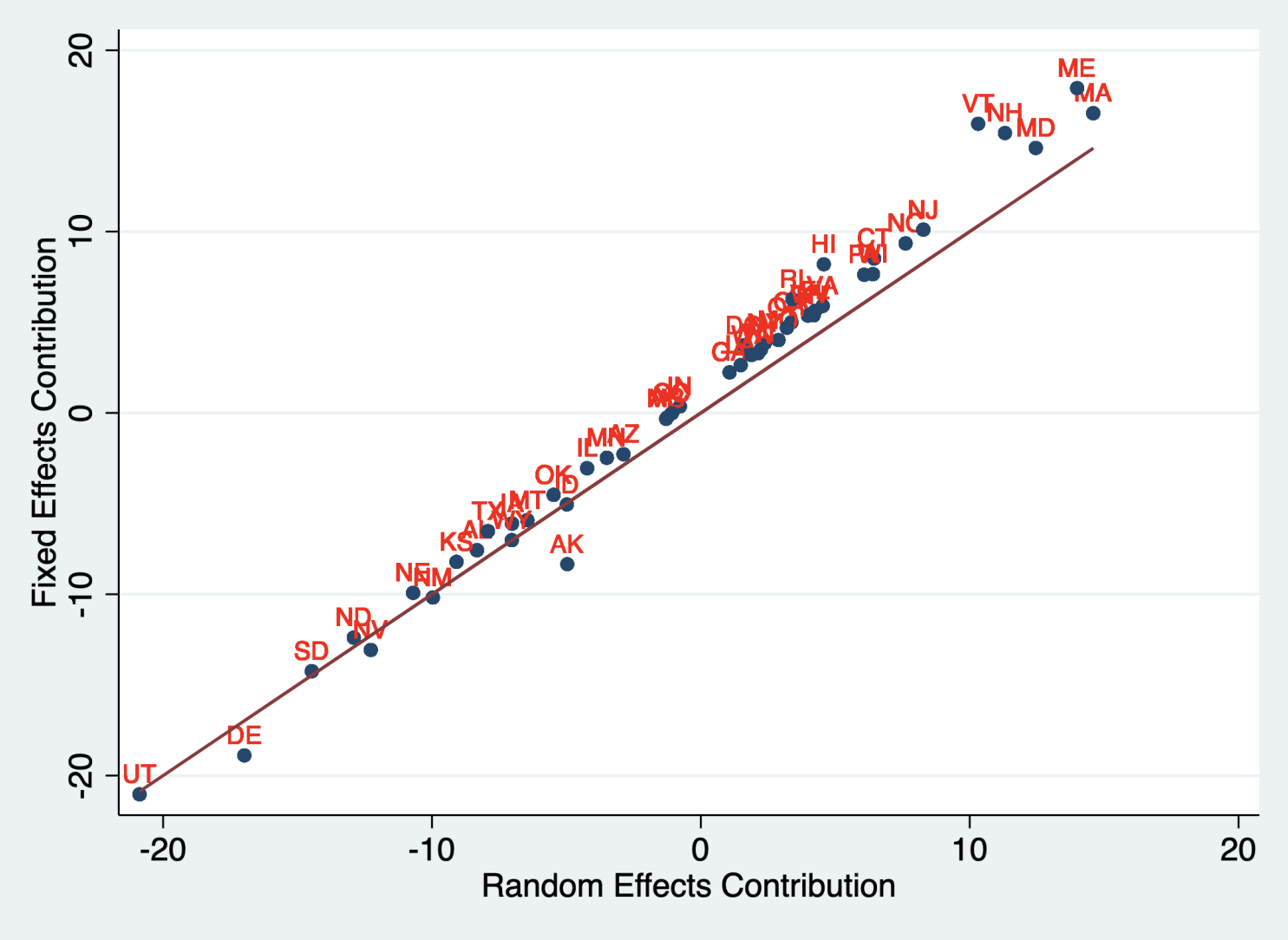


Figure 2.17: Decomposition of Random Effects for Real Estate Loans, 2017

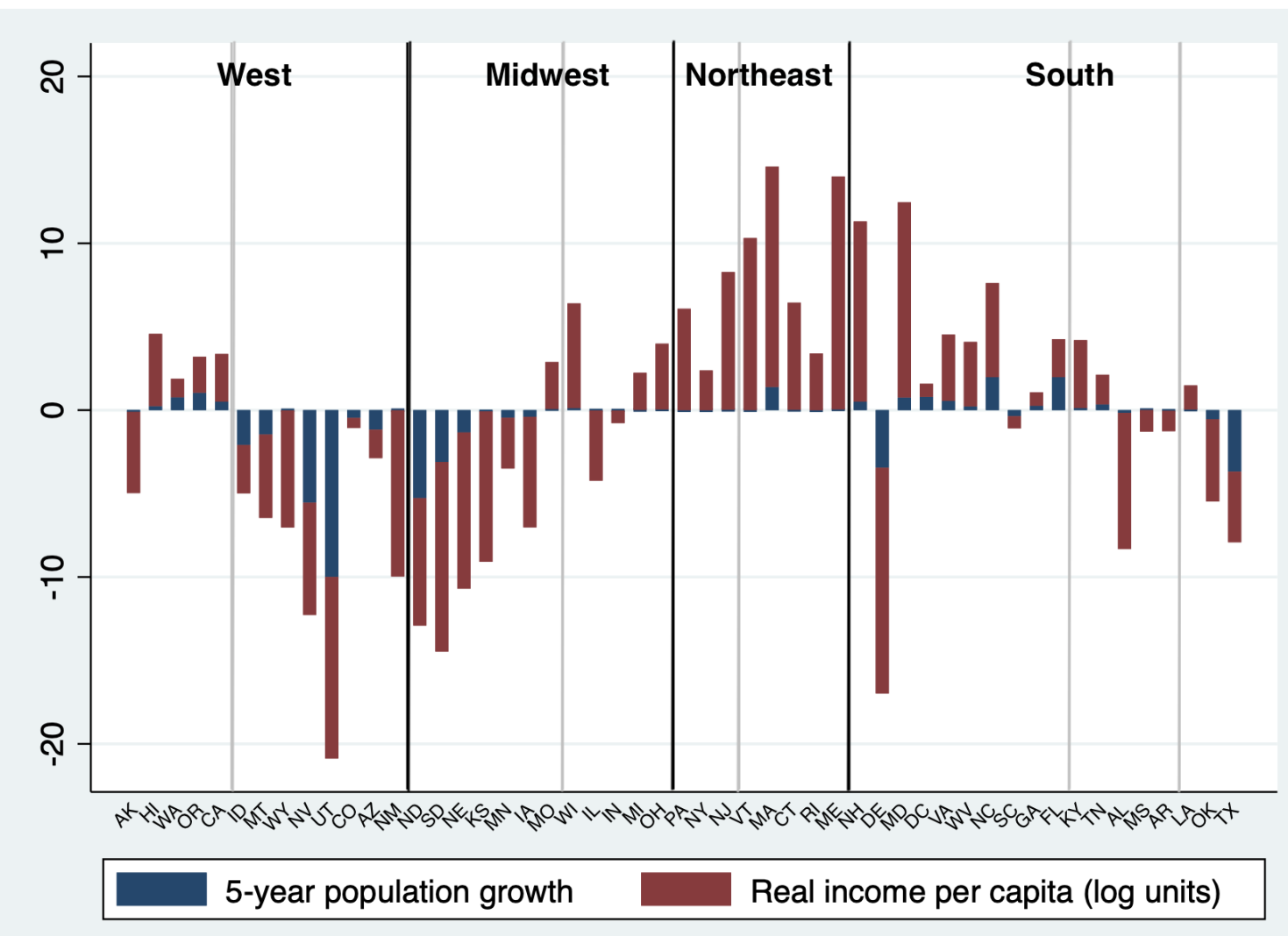




\section{Chapter 3}

\section{A State-Level Analysis of the Cost}

\section{Efficiency of U.S. Community Banks}

\subsection{Introduction}

This research generates aggregate cost efficiency measures for U.S. state community banking (CBs) markets using data from 2013 to 2018 . This aggregate measure is estimated based on the annual weighted-deposit average estimates of the cost efficiency of U.S. community banks (CBs) operating in each state in the United States, which is a contribution of this study. This analysis is motivated by the Riegle-Neal Interstate Banking and Branching Efficiency Act of 1994, which drastically changed the market composition of the U.S. banking industry as it allowed banks to operate in more than one state and led to a faster consolidation of the industry.

Given the differences in the timing of adoption of this regulation across U.S. states, it is possible that the asymmetric implementation of this policy can explain differences in performance across banks in different states. ${ }^{1}$ This study explores if and where such differences emerge geographically when comparing the U.S. state local banking markets in one dimension, cost efficiency. Assaf et al. (2019) emphasize the importance of studying the cost efficiency of banks. Their results find that a

\footnotetext{
${ }^{1}$ Moreover, even though this regulation allowed banks to operate in more than one state, it also allowed states to impose state-specific anti-competitive restrictions related to the entry of out-of-state banks (Johnson and Rice, 2008).
} 
higher level of cost efficiency lowers the probability of bank failure during downturns in economic activity; hence, their results show that a bank's cost efficiency can be associated with its ability to provide its customers liquidity services.

This paper also contributes to the literature by updating the cost efficiency measures of almost two decades ago from Berger and Mester (1997). Following the methodology from Assaf et al. (2019), a bank's cost efficiency is estimated using the parametric cost frontier distribution-free approach (DFA) to a panel micro U.S. banking data set. The parametric methodology is chosen over the nonparametric due to its ability to decompose the difference between a bank's current and predicted optimal performance in two components, the random error term and the firm-specific inefficiency component.

The FDIC defines CBs as banks which (1) the business model focuses on transforming core deposits into loans, (2) operates in three or fewer states and two or fewer MSAs, and (3) fall under the indexed size threshold of one billion dollars in total assets (FDIC, 2012). The focus on CBs improves the estimation of the applied methodology. This sample selection criterion better accommodates the strong output homogeneity assumption imposed by the methodology applied and, combined with better data availability, reduces problems with outliers, which allows for lower winsorization adjustments. The study of community banks (CBs) is specially important given that they compose $91 \%$ of all U.S. banks and their specialization in providing relationship loans to financially constrained borrowers. Moreover, it also makes the findings of this paper more applicable to states which economies are more dependent on small businesses' and/or that have larger share of non-metropolitan areas.

This research finds that U.S. banks' ability to minimize cost, given output and market input prices, when compared to the best performing bank in that period has deteriorated in the past two decades. $^{2}$ The average relative current cost-efficiency of CBs has fallen by at least $30 \%$. The preferred specification of this study reports that CBs are, on average, $45.6 \%$ efficient relative to the

\footnotetext{
${ }^{2}$ One may be worried about the differences in bank sample between this study and Berger and Mester (1997). However, given that both papers find that geographical expansion is associated with lower levels of bank performance, the fact that this research only considers community banks can actually underestimate the differences in performance across both sample periods.
} 
most efficient $\mathrm{CB}$ if facing the same environmental conditions. This deterioration in relative cost efficiency suggests subsequent work should explore what has impacted banks' ability to perform as well as the best performing bank if facing the same environmental conditions. As a simple first step to investigate the current determinants of a bank's cost efficiency, a micro banking OLS regression is applied to investigate which regional and banking characteristics are associated with higher performance levels. Despite providing suggestive results, this methodology allows for a comparison with the results provided by Berger and Mester (1997).

The relationships between several variables have changed in since the mid-1990s. Younger, independent (not owned by a bank holding company (BHC)), and holding more loans in its balance sheet are now positively associated with better cost minimization. In terms of regulator agency, banks regulated by the FDIC, relative to OCC-regulated banks, are associated with better costefficiency levels. Customer characteristics, such as wealthier clients and clients living in states more dependent on agriculture, are also positively related to bank performance. The reasoning behind these results are further elaborated in Results Section. However, it is important to highlight that the regression analysis reports that banking and regional characteristics explain only $19.2 \%$ of the variation in the cost efficiency of CBs; however, even though small, this is significantly higher than the $7 \%$ reported by Berger and Mester (1997) for all U.S. banks.

Despite mainly fitting into the banking literature, this article further emphasizes the need to further investigate the interaction between regional financial markets and regional economic outcomes. Using a micro-macro approach, this paper is the first to generate cost efficiency estimates for U.S. state banking markets. A micro-macro approach refers to the process of using micro-level banking data to generate banking markets aggregate measures. The cost efficiency of CB markets is found to be heterogeneous across U.S. states, as top performing states are found to be on average nearly twice as efficient as the least efficient ones.

Lastly, through the analysis of pairwise correlations, this study also takes a first step towards investigating if the variation in the cost efficiency of banking markets is linked to differences in socioeconomic outcomes across U.S. states. Motivated by results from the literature papers 
discussed in Section 3.2.2, the socioeconomic variables considered in analysis are the growth rate of real income per capita and labor market outcomes. The results show the presence of a significant negative correlation between the cost efficiency of a state's CB market with its unemployment and job destruction rates. No significant relationship is not found between banking market performance and real income growth. These are findings my future research will continue to investigate using a larger sample period and more sophisticated econometric models.

\subsection{Literature Review}

This section is split into two parts. First, the paper briefly describes the literature on the costefficiency of U.S. banks, while the second subsection summarizes the literature that studies the relationship between banking activity and regional economic outcomes.

\subsubsection{Cost Efficiency: Banking Application}

The U.S. banking cost efficiency literature had its peak in the 1990s when several authors investigated the most appropriate methodology to estimate the the efficiency of U.S. banks; these include Berger and DeYoung (1997), Mitchell and Onvural (1996), Berger and Humphrey (1997), Hughes et al. (1996), among others. Berger and Mester (1997) provide a comprehensive summary of this literature. Their paper compare and contrast the cost efficiency of U.S. banks given the use of different estimation approaches.

The authors report two main cost frontier methodologies have been applied, parametric and nonparametric cost frontier estimation approaches. There are trade-offs between these approaches, but the parametric estimation's main advantage is its ability to disentangle the composite error, the difference between a firm's current and optimal performance, in two components: the random error term and the firm-specific inefficiency component. The methodology section will further describe the differences between these two frontier estimation techniques. Moreover, despite the large number of papers publish on this topic in the 1990s, the large majority of studies using cost 
efficiency since then have focused on studying European banking systems, countries, and regions. Given differences in institutional composition, regulation, and culture, these papers will not report non-US results. A list of the papers for this European banking literature can be provided upon request.

However, a recent study from Assaf et al. (2019) brought attention again to this performance measure when applied to U.S. banks. The authors report the existence of a positive link between the cost efficiency of U.S. banks and their ability to continue to provide services to its customers during recessions. Motivated by this finding, this research estimates the core cost efficiency of U.S. community banks from 2013 to 2018. The reason for the selection of this specific 6-year period is twofold: (1) Assaf et al. (2019) estimate the cost-efficiency of banks using data from the 2007-08 Great Recession, which hints at the need for evaluation of this measure in a more recent period; and (2) the length of this period is chosen to optimize the estimation of the cost efficiency of banks. Despite such contribution to the literature, this study is not the first to connect banking activity with regional economic outcomes.

\subsubsection{The Importance of Regional Banking}

The study of the relationship between the U.S. banking industry with regional socioeconomic outcomes deserves attention given the important roles bank have in the U.S. economy. Given that we live in a world of imperfect information, banks efficiently solve asymmetric information issues between borrowers and savers (Flannery, 1982). This is accomplished through the brokerage, and qualitative asset transformation (QAT) functions they perform.

The brokerage function refers to the comparative advantage banks have in dealing with precontract adverse selection and post-contract moral hazard issues. This function, presumably, leads to the allocation of credit to its highest and best use. Moreover, its QAT function increases the probability of finding a counterpart for any transaction. This is done through asset transformations related to maturity, divisibility, risk of default, and exchange rate risks. Given the important roles of banks in reducing transaction and intermediation costs, their absence can generate liquidity 
constraint problems for local businesses and households, which can have a negative impact on local economic growth. ${ }^{3}$

In addition to differences in the presence of banks across states, differences in financial behavior of banks operating in a state can also impact regional economic growth. According to Samolyk (1994), Khan and Ozel (2016), and Duygan-Bump et al. (2015) differences across banks' loan portfolio information can impact growth and labor market outcomes across different geographical regions, especially of states/counties facing high demand for loans. In addition, Carpenter et al. (2020) finds that the share of locally owned banks is positively related to business births and deaths in rural counties; but, the inverse effect is reported for metropolitan areas.

Given that a banks financial behavior can also be impacted by changes in regulation, these changes also deserve attention here. Danisewicz et al. (2018) emphasize that increasing the regulatory burden over local banks has harmed income growth and the number of establishments while also increasing unemployment across U.S. counties. ${ }^{4}$ Furthermore, Berger et al. (2020) report that bank deregulation leads to higher credit availability to unconstrained firms but limits the access of constrained ones (firms more dependent on relationship loans).

The results reported by Barth et al. (2016) and Minuci and Schuh (2021) further emphasize the presence of differences in bank performance and composition across U.S. state banking markets. For instance, Barth et al. (2016) show that the returns on assets (ROA) of banks during the Great Recession of 2007 was not uniform across banks headquartered (HQ) in different states. Moreover, Minuci and Schuh (2021), using more recent data, report that such differences are also found when analyzing the current investment strategy of banks in different state markets.

Table 3.1's max. and min. columns emphasize the large yearly variation of banking characteristics across U.S. states from 2013 to 2018. Differences in state banking market characteristics are noted across the board in terms of size (number of branches or offices per bank), bank composition (represented by the share of banks which are CBs and the share of deposits they hold), bank investment strategy (represented by the share of loans to assets ratio), and market concentra-

\footnotetext{
${ }^{3}$ For instance; loan prices would rise as we would observe an adverse shock in the supply of loans.

${ }^{4}$ These regulatory changes are related to contractions in bank lending and liquidity creation.
} 
tion (reported through the Herfindahl-Hirschman Index of bank state deposits). Combined with the commonly known differences in socioeconomic outcomes across states, these factors suggest further exploration between regional banking markets and regional outcomes is needed.

In summary, according to the regional banking literature, bank type and performance can impact economic activity in the areas they operate. Moreover, since the composition and performance of banks operating across different U.S. states are not uniform, this study takes a step towards further evaluating the relationship between banking markets' performance and regional outcomes by estimating a more sophisticated performance measure, cost efficiency, using a micro-macro approach to generate a comprehensive measure that can evaluate the performance of a state local banking market.

\subsection{Data}

This study will study the core cost efficiency of U.S. banks from 2013 to 2018. The reason for the selection of this specific 6-year period is twofold: (1) Assaf et al. (2019) estimate the costefficiency of banks using data from the 2007-08 Great Recession, which hints at the need for evaluation of this measure in a more recent period; and (2) the length of this period is chosen to optimize the estimation of the cost efficiency of banks. ${ }^{5}$ Moreover, several data sources were used to evaluate the research question proposed in this article.

Data for state-level socioeconomic characteristics come from a combination of the Census, for population data, and the Bureau of Labor Statistics, for employment data. These characteristics are reported yearly.

Banks, in this study, are defined as all financial institutions which report to the FDIC. Banking data comes from three sources. Consolidated banking data comes from the Call Report Data and Summary of Depository Institutions. These are quarterly unbalanced time series data, which contains information about the balance sheet and income statement of these institutions. ${ }^{6}$ I exclude

\footnotetext{
${ }^{5}$ This will be further explained in the Methodology section.

${ }^{6}$ Income statement variables are properly annualized when necessary.
} 
foreign banks due to lower data availability. Moreover, branch-level data is reported yearly and contains information on the location and specialization of the branches, the regulator, and the type of each bank. ${ }^{7}$ All variables adjusted for inflation with a base year of 2018.

\subsection{Methodology}

From a neoclassical producer theory perspective, a necessary condition for a firm to be profitmaximizing is to minimize cost. In this framework, a firm will choose the output level that maximizes profit, assuming it will choose the input bundle that minimizes the cost of producing that output level at current input prices.

In a banking application, since their business model involves using deposits to make loans, a bank's production cost depends on the expenses spent to gather such funds. A possible way to evaluate a firm's ability to minimize its cost of production is through the use of cost frontiers. This methodology estimates the difference between a bank's total cost and the minimized total cost from the predicted optimized cost frontier, the composite error term. Several econometric techniques can estimate the cost frontier and, hence, firms' inefficiency.

\subsubsection{Cost Efficiency Estimation for Banks}

In a banking application, since the underlying technology of these firms' production process is unobserved, efficiency is generally defined relative to the best-practice bank in the industry. Hence, the cost-efficiency of a bank is generally defined by the ratio between (1) the cost needed to produce the bank's output if the bank was as efficient as the best-practice bank in the industry, given that it was facing the same environmental conditions and input bundle prices, and (2) its current production costs.

Methods applied to estimate the cost efficiency of U.S. banks varied in the 90s between parametric or nonparametric. Berger and Mester (1997) emphasize that the main advantage of paramet-

\footnotetext{
${ }^{7}$ This data is released yearly during the second quarter of the year.
} 
ric methods is that they consider input prices and, thus, capture both the technical and allocative efficiency skills of a bank. Allocative efficiency is associated with not properly responding to relative prices when choosing bundles of inputs and outputs for production. Given that this research is interested in these institutions' economic optimization process, a parametric frontier estimation is used.

Moreover, other technical differences between both methods deserve attention. For instance, nonparametric models also have a stronger output homogeneity requirement when comparing performance across banks. Despite not requiring an explicit definition of the cost function, a requirement of the parametric approach, the nonparametric approach cannot disentangle the composite error term's inefficiency and random error term components. Hence, it carries the risk of confusing random deviations with deviations from the frontier. This, however, is achievable in the parametric estimation by making explicit assumptions about their distributions.

Bauer and Hancock (1993) highlight concerns about the validity of setting distributional assumptions for the distribution of the composite error term when investigating U.S. banks. ${ }^{8}$ Nonetheless, Berger (1993) report that these concerns are minimized if panel data is available since the Distribution-Free Approach (DFA) becomes an option. In the DFA parametric estimation, one first assumes that each bank has a core, or average, efficiency over the period under study. Such efficiency can be set apart from its temporary fluctuations due to the assumption the model imposes that such fluctuations average out to zero over time. For this assumption to hold, Berger and Mester (1997) and DeYoung (1997) state that the selection of 6 years is optimal. This paper applies this approach for the micro-level U.S. banking quarterly data set from 2013 to $2018 .^{9}$

The methodological approach applied to estimate the cost efficiency of U.S. banks in this study is the same used by Assaf et al. (2019). Thus, the cost function is defined to be dependent on the vector $w$ of given input prices, $q$ of given output quantities, and the composite error. The composite error term can then be decomposed between the inefficiency component, $u$, and a random error

\footnotetext{
${ }^{8}$ Earlier research commonly assumed the composite error term followed a half-normal distribution.

${ }^{9}$ As a robustness check, the cost efficiency of banks estimated in this study is also estimated using a period of 5 , $5.5,6,6.5$, and 7 years. The results are strongly robust and can be provided upon request.
} 
term, $\varepsilon$. In a banking application, the vectors $z$ and $v$ are also included to control for potential scale bias and environmental factors, respectively. Moreover, note that in this case, the vector of input quantities can be omitted in the estimation process. ${ }^{10}$

Therefore, the total short-run cost function of a $\mathrm{CB}$ at time $t$, where $t$ represents quarterly frequency, can be written as:

$$
C_{i t}=F\left(w_{i t}, q_{i t}, z_{i t}, v_{i t}, u_{i t}, \varepsilon_{i t}\right)
$$

which then allows one to derive the relative core cost efficiency of a bank $i, \hat{E}_{i}$, through the equation,

$$
\hat{E}_{i}=\frac{\hat{C}_{\text {min }}}{\hat{C}_{i}}=\frac{\exp \left[\hat{c}\left(w_{i}, q_{i}, z_{i}, v_{i}\right)\right] \times \exp \left[\ln \hat{u}_{\text {min }}\right]}{\exp \left[\hat{c}\left(w_{i}, q_{i}, z_{i}, v_{i}\right)\right] \times \exp \left[\ln \hat{u}_{i}\right]}=\frac{\hat{u}_{\text {min }}}{\hat{u}_{i}} \quad \text { with } \hat{E}_{i} \in(0,1]
$$

where,

$$
\hat{u_{\min }}=\min \left\{\hat{u_{1}}, \hat{u_{2}}, \ldots, \hat{u_{N}}\right\}
$$

with $N$ referring to the number of CBs in the data set. In this case, the subscript $t$ is omitted since this methodology assumes that the core cost efficiency of a bank is time invariant as it is estimated by averaging the inefficient components of a bank across all $t$.

The estimation considering all banks is not reported in this study since it does not accommodate the strong output quality homogeneity assumption imposed by this approach. This sample selection criterion is a technical contribution provided by this study.

\subsubsection{Input Prices and Output Variables}

Following Assaf et al. (2019), a bank's total costs is calculated by the sum of interest and noninterest expenses. Its cost frontier is then estimated based on the output bundle chosen for production given such input prices. The noninterest expenses considered are the price of labor (total personnel expenses per full-time employee), $w_{1}$, the price of physical capital (total operating and administrative expenses to total premises and fixed assets), $w_{2}$, the price of purchased funds (total interest

\footnotetext{
${ }^{10}$ This can be derived by solving the Kuhn-Tucker conditions from the economic cost minimization problem of a bank provides the Conditional Factor Demand Function that $I$ is a function of both $w$ and $q$.
} 
expense subtracted by core deposits interest expenses per dollar of core deposit accounts), $w_{3}$, and the price of core deposits, $w_{4}$. A bank's output is calculated by the sum of one's value of total consumer loans, $y_{1}$, commercial and industrial (C\&I loans), $y_{2}$, residential real estate, $y_{3}$, commercial real estate, $y_{4}$ and other loans (total loans minus the four asset components above), $y_{5}{ }^{11}$

Moreover, $z$ is composed of $z_{1}$ and $z_{2}$, which define the notional value of a bank's off-balance sheet activities and its level of financial equity capital, respectively. ${ }^{12}$ Lastly, $v$ accounts for the risk exposure a bank faces, which is approximated here by the weighted average ratio of nonperforming loans located in states a bank operates in (Berger and DeYoung (1997), Berger and Mester (1997), Assaf et al. (2019)). The selection of output follows the arguments in favor of modern banking theories presented by Assaf et al. (2019), in which banks intermediate deposits into loans and also engage in off-balance sheet activities. ${ }^{13}$ Table 3.2 summarizes information on the variables included in the cost estimation of CBs.

\subsubsection{Cost Function Specification}

As common in this approach, the inefficiency and random error terms are assumed to be multiplicatively separable from the cost function (Berger and Mester (1997), Assaf et al. (2019)). Thus, for this study Equation 1 can be rewritten as:

$$
\ln C_{i t}=c\left(w_{i t}, q_{i t}, z_{i t}, v_{i t}\right)+\ln u_{i t}+\ln \varepsilon_{i t}
$$

Furthermore, I opt for the Fourier-flexible functional form, which complements the standard second-order translog function specification by adding Fourier trigonometric terms. Thus, in the equation above the function $c$ represents the natural $\log$ of the function $F$ in Equation 3.1. Berger

\footnotetext{
${ }^{11}$ One may wonder whether the level of deposits a bank holds should be considered part of its output bundle since they are a type of service provided by these institutions. However, the previous literature emphasizes that results tend to stay robust independently of the inclusion of deposits as output. Despite following the literature reporting the main results, I also re-run my analysis, including deposits as output as a robustness check. Results are fairly similar and show a slightly higher cost-efficiency. These can be provided upon request.

${ }^{12}$ Equity directly affects the cost of providing an alternative to deposits as a funding source for loans. Interest paid on debt is an expanse, but dividends paid are not. Nonetheless, raising equity is also more costly than raising deposits.

${ }^{13}$ Under these theories, securities are better thought of as inputs to the banking functions rather than outputs. This, however, does not change the nature of the results presented in this study.
} 
and Mester (1997) and Assaf et al. (2019) emphasize this to be the optimal functional choice for the cost estimation of banks given its higher flexibility relative to the traditional translog approach. Moreover, they argue this specification serves as a global approximation to virtually any cost or profit function. Therefore, the cost function specified for empirical estimation is defined by the following equation:

$$
\begin{aligned}
\ln \left(\frac{C}{w_{4} z_{2}}\right) & =\delta+\sum_{h=1}^{3} \beta_{h} \ln \left(\frac{w_{h}}{w_{4}}\right)+\frac{1}{2} \sum_{h=1}^{3} \sum_{j=1}^{3} \beta_{h j} \ln \left(\frac{w_{h}}{w_{4}}\right) \ln \left(\frac{w_{j}}{w_{4}}\right) \\
& +\sum_{k=1}^{5} \gamma_{k} \ln \left(\frac{q_{k}}{z_{2}}\right)+\frac{1}{2} \sum_{k=1}^{5} \sum_{m=1}^{5} \gamma_{k m} \ln \left(\frac{q_{k}}{z_{2}}\right) \ln \left(\frac{q_{m}}{z_{2}}\right)+\delta_{1} \ln \left(\frac{z_{1}}{z_{2}}\right) \\
& +\frac{1}{2} \delta_{11} \ln \left(\frac{z_{1}}{z_{2}}\right) \ln \left(\frac{z_{1}}{z_{2}}\right)+\frac{1}{2} \sum_{h=1}^{3} \sum_{k=1}^{5} \lambda_{h k} \ln \left(\frac{w_{h}}{w_{4}}\right) \ln \left(\frac{q_{k}}{z_{2}}\right) \\
& +\sum_{h=1}^{3} \rho_{h} \ln \left(\frac{w_{h}}{w_{4}}\right) \ln \left(\frac{z_{1}}{z_{2}}\right)+\sum_{k=1}^{5} \tau_{k} \ln \left(\frac{q_{k}}{z_{2}}\right) \ln \left(\frac{z_{1}}{z_{2}}\right)+\sum_{n=1}^{9}\left[\phi_{n} \cos \left(x_{n}\right)+\omega_{n} \sin \left(x_{n}\right)\right] \\
& +\sum_{n=1}^{9} \sum_{g=1}^{9}\left[\phi_{n g} \cos \left(x_{n}+x_{g}\right)+\omega_{n g} \sin \left(x_{n}+x_{g}\right)\right] \\
& +\sum_{n, n^{\prime}, n^{\prime \prime}=1}^{9}\left[\phi_{n n^{\prime} n^{\prime \prime}} \cos \left(x_{n}+x_{n^{\prime}}+x_{n^{\prime \prime}}\right)+\omega_{n n^{\prime} n^{\prime \prime}} \sin \left(x_{n}+x_{n^{\prime}}+x_{n^{\prime \prime}}\right)\right] \\
& +\zeta_{1} \ln v+\ln u+\ln \varepsilon .
\end{aligned}
$$

I omit the subscripts $i$ and $t$ for easier visualization. However, this methodology estimates the short-run total cost for each community bank, $i$, in each time period, $t$. The core inefficiency component, $u$, is the only variable which is time invariant in this estimation as it determines the core inefficiency component of bank $i$.

Two normalization techniques are introduced in Equation 3.4. First, I normalize total costs and input prices by the average cost per dollar of core deposits to ensure linear homogeneity. This ensures that total costs move proportionally to changes in the cost of all input prices. Moreover, the normalization of total costs, output quantities, and $z_{1}$ by $z_{2}$ ensures the comparability among banks by further reducing the risk of scale bias on the regression results. The usual symmetry, 
homogeneity, and adding-up constraints are also imposed in the estimation procedure. These are standard normalization procedures implemented in banking applications (Assaf et al., 2019).

Lastly, two winsorizing approaches, common to the literature, are implemented to reduce extreme outliers' impact on results. I winsorize by $10 \%$ of the end of each interval, $[0,2 \pi]$, of $x_{n}$ to reduce approximation problems near the distribution endpoints. ${ }^{14}$. In addition, the literature also highlights the possibility of outliers due to the inability of the model to completely purge out the random error through averaging. As a response, previous papers winsorize the distribution of banks' estimated core inefficiency component at the 95th percentile. Given improvements in the quality and quantity of data available for U.S. banks over the past two decades, I also generate results using the 99th percentile winsorizing approach for comparison.

\subsection{Results}

To report the results clearly and concisely, this section is divided into three subsections. First, this study explores the results related to estimating the cost efficiency of U.S. community banks at the national level. Second, it explores potential banking and regional characteristics associated with variation in such efficiency measurement. Lastly, a state-level analysis is conducted to evaluate the variation in banking markets' cost efficiency across U.S. states.

\subsubsection{Bank-Level Cost Efficiency Results}

As described in the Methodology section, based on the results from the GLS random-effects model (Table 3.3) one can compute the predicted core cost efficiency, $u_{i}$, for each bank $i$. The micro-level cost efficiency estimation results are reported in Table 3.4 and Figure 3.1.

The average cost efficiency across U.S. community banks ranges from 45.6 to $61.3 \%$, depending on the winsorization approach. Results show that CBs' performance is significantly lower than

\footnotetext{
14"The formula for $x_{n}$ is $(0.2 \times \pi-\mu \times a+\mu \times$ variable $)$, where $[a, b]$ is the range of the variable being transformed and $\mu=(0.9 \times 2 \pi-0.1 \times 2 \pi) /(b-a)$." (Assaf et al., 2019)
} 
the $86.8 \%$ relative cost efficiency estimates from Berger and Mester (1997). ${ }^{15}$ It is important to highlight that the comparison here is not in terms of the magnitude of cost efficiency, rather it illustrates the lower ability to current banks to perform as well as the best performing bank if facing the same environmental conditions. Furthermore, this agrees with Berger and Mester (2003), who state that, in the early 2000s, bank cost productivity worsened while profit productivity increased. This is worrisome given the important link between cost efficiency and banks' ability to provide their customers' liquidity services.

Despite the common use of the literature of the 95th percentile, this study hereon opts for analyzing only results based on 99th percentile estimates motivated by a couple of factors. First, Table 3.4 highlights how this stronger winsorization adjustment seems to shift the first and second moments of the distribution of U.S. banks' cost efficiency by affecting the firms selected as the best performing banks in the sample. Moreover, results provided using the 99th percentile do not seem to suffer significant problems related to the presence of outliers discussed by the literature. ${ }^{16}$ This can potentially be due to the higher data accuracy of bank reports during more recent periods. Hence, given the reasons above combined with a preference for staying closer to the reported data, the 99th percentile winsorized results are preferred.

\subsubsection{Empirical Investigation of Potential Correlates with Cost Efficiency}

Similarly to Berger and Mester (1997), this paper conducts a bank-level linear regression to evaluate the relationship between cost efficiency and banking and regional characteristics. In this study, $\hat{E}_{i}$, from Equation 3.2, is modeled to be explained by $\alpha_{0}$, a vector of bank characteristics, $\bar{X}_{i}$, a vector of regional characteristics (which includes both banking market composition and socioeconomic characteristics), $\bar{G}_{i}$, a common constant across banks, and a random error term $e_{i}$. Furthermore, given that the cost efficiency methodology used generates a time-invariant cost-efficiency

\footnotetext{
${ }^{15}$ Since Berger and Mester (1997)'s sample includes all U.S. banks, I re-estimated my methodology including all banks as a robustness check. Despite not reporting the results in this paper, including noncommunity banks slightly lowers U.S. banks' average cost efficiency. These estimates can be provided upon request.

${ }^{16}$ The histogram of the distribution of the core inefficiency component of banks, $u_{i}$, can be provided upon request.
} 
measure, time-varying variables included in the regression are six-year averages. Table 3.5 reports the definition and descriptive statistics of the variables included in the empirical investigation conducted based on Equation 3.5.

Due to cost efficiency being an estimated measure, and its standard error not being accounted for in the following regression, the results presented are suggestive but not conclusive. Nonetheless, this regression still provides a contribution to the literature given that the comparison of its results with the results from Berger and Mester (1997) can illustrate how the changes the banking industry has experienced in the past decades have affected the potential determinants of bank performance.

$$
\hat{E}_{i}=\alpha_{0}+\alpha_{1} \bar{X}_{i}+\alpha_{2} \bar{G}_{i}+e_{i}
$$

The results of this empirical investigation, including all CBs, from the first quarter of 2013 until the last quarter of 2018, are reported in column 1 of Table 3.6. Furthermore, given potential concerns one may have about the accuracy of regional characteristics of banks operating in more than one state, column 2 reports the results only for community banks that operate in a single state (community single-market banks, CSMBs). CSMBs represent over $90 \%$ of all CBs. The results are robust in the sense that the average relative cost efficiency changes by less than $1 \%$.

The results suggest that policies related to reducing bank risk-taking behavior can be associated with lower levels of cost-efficiency. This can be observed by the negative coefficient of the variable indicating whether a bank is owned by a bank holding company (BHC). This result agrees with the hypothesis that bank ownership expansion is correlated to increases bank risks (Goetz et al., 2016). Younger banks also seem to be more cost-efficient.

Moreover, the preference for the asset portfolio allocation towards loans seems to have an opposite impact relative to the preference for off-balance sheet activities. ${ }^{17}$ Given that loans are perceived as more secure than off-balance sheet investment contracts, a bank preference for relatively riskier assets, not surprisingly, is related to a higher probability of bank failure, which is proxied by a bank's cost efficiency. Thus, policies that encourage banks to hold safer assets can

\footnotetext{
${ }^{17}$ These include investments on derivative contracts, such as swaps, forwards, and futures.
} 
lead to better provision of liquidity services by CBs.

This study also finds that better bank performance is negatively correlated with bank geographic expansion, while some customer characteristics have the opposite effect. For instance, results show that access to wealthier customers and a population economically dependent on agriculture, proxied by the share of branches specialized in agricultural type loans, lead to better costefficiency. The latter can be seen as a proxy for regions where customers tend to be highly dependent on agricultural markets, which seems to enable $\mathrm{CBs}$ to minimize its short-run production costs better and, thus, better provide liquidity services to its customers.

Other bank characteristics explored include the bank's main regulator. Banks regulated by the FDIC relative to banks regulated by the Office of Comptroller of the Currency (OCC) seem to face a regulatory environment that enables banks to minimize short-run costs more efficiently. Another type of bank regulator is the Federal Reserve, which is also positively correlated with CB's costefficiency. This is evaluated by including a dummy defining whether a CB is considered a savings association. CBs considered savings associations are financial institutions which specialize in relationship loans with a focus on real estate. Thus, regulatory differences could be one of the reasons why savings institutions are, on average, more efficient than CBs. However, this paper does not focus on the investigation of the specific regulatory differences that could be driving these results.

Lastly, CB deposit concentration does not seem to be associated with variation in the cost efficiency of CBs; however, this can be due to counterbalancing forces this variable suffers given that an increase in CB's state deposit HHI could mean an increase in its own share of state deposits or an increase in another bank's share. Nonetheless, when considering an increase in the concentration of deposits of all other banks, we note that rises in bank concentration tend to promote higher bank efficiency. Share of deposits held by $\mathrm{CBs}$ in operating markets is not related to variations in cost efficiency across CBs.

The correlates included in this analysis account for $19.2 \%$ of the variation in U.S. community banks' cost-efficiency. Despite these variables' apparent low ability to explain a bank's cost effi- 
ciency, this result is significantly higher than the 7\% reported by Berger and Mester (1997) for all U.S. banks. This can potentially be attributed to two factors: (1) the many technological and data reporting regulatory changes the banking industry has experienced in the last two decades, and (2) the sample selection criterion used, which focus on a less heterogeneous sample of U.S. banks.

The results highlight the relevance of the re-evaluation of banks' cost efficiency and its main determinants after changes in regulation and banking markets' composition. Bank ownership, age, loan to asset ratio, and regulator are reported to have a different relationship with cost efficiency relative to the early 1990s. Understanding which banking and customer characteristics are associated with lower levels of cost-efficiency can help regulators identify banks underperforming; in other words, banks that are not able to provide liquidity to its customers during periods of downturn in economic activity. A natural follow-up question is whether this performance measure of cost efficiency actually has significant affects on socioeconomic outcomes where such banks operate. The next section takes a step towards answering to this question by using a micro-macro approach to generate cost efficiency estimates for U.S. state banking markets.

\subsubsection{State-Level Analysis}

This paper contributes to the literature by being the first to generate an aggregate proxy for the ability of community banking markets across U.S. states to provide liquidity to its clients during recessions. To accomplish this aggregation task, this research defines the cost efficiency of a state community banking market as the yearly weighted average of the core cost efficiency of the CBs operating in the state. The weights are determined by the share of state CB deposits each CB holds. This weighting scheme takes into consideration the market presence of each bank in a state. This micro-macro approach can also be defined by:

$$
\hat{E}_{s y}=\sum_{i=1}^{N_{s y}} \alpha_{i s y} \hat{E}_{i}
$$

where $\alpha_{i s y}$ denotes the share of state deposits held by community bank $i$ in state $s$ of year $y$. 
This aggregation is done on an yearly basis due to the availability of the frequency of branch deposits data. This section, however, focus only on evaluating the average cost efficiency of a banking market from 2013 to 2018. Given that the core cost efficiency of a bank is time invariant, the yearly variation of market performance would represent the impact of entry and exit of banks in a market. Despite being an interesting question, such question is beyond the scope of this paper. Figure 3.2 reports the average of $\hat{E}_{s y}$ over the period under study using a heat map of U.S. states.

The figure shows heterogeneity across the ability of different state banking markets to provide liquidity services to its customers. Nevada, Massachusetts, and Utah are the most efficient state banking markets with an average cost efficiency of $61.27 \%$. In contrast, the least efficient banking markets, New Mexico, Alaska, and Arizona, are, on average, nearly half as efficient than the most efficient states. Identifying which banking markets are not performing well can help regulators identify areas more likely to suffer from community bank failures during a financial crisis. This can allow regulators to be pro-active rather than reactive towards improving banking markets not performing well.

Furthermore, this research also takes a first step towards investigating the determinants of cost efficiency of CB markets across U.S. states. This is accomplished by generating and evaluating a correlation matrix including the aggregate performance measures for community banking markets and socioeconomic characteristics that can reflect economic growth, size of customer base, and labor market outcomes. The results for this analysis can be observed in Table 3.7.

Motivated by Khan and Ozel (2016) and Duygan-Bump et al. (2015), this section evaluates the linear relationship between the aggregate banking market performance with economic growth and labor market outcomes. The data does not show a significant relationship between the level of a CB market cost efficiency and the economic growth of its market. This could be explained by the fact that Khan and Ozel (2016) use a simple aggregated measure of bank performance which include all banks, and not simply community banks. Hence, the relationship they report could be driven by the behavior of large multi-market banks (non-CBs).

CBs play a special role providing liquidity to small businesses and financially constrained 
borrowers (Berger et al., 2017). Thus, given the high relevance of small businesses to the U.S. labor market, this research hypothesizes that better $\mathrm{CB}$ market performance is associated with better labor market outcomes. As reported in Table 3.7, such hypothesis is indeed present in the data. Furthermore, given the nature of CBs in serving financially constrained borrowers specially during periods of downturn in economic activity, this study also explores the relationship of this measure with the two other labor market measurements, the job destruction and the job creation rate.

The job destruction rate represents the average rate of employment losses during this sample period, while the job creation rate represents the average rate of employment gains. The data shows that banking markets which perform at a higher cost efficiency level tend to experience lower job destruction rates, which is not a surprise since job losses can be associated with lack of ability of business to borrow to maintain current levels of production (Duygan-Bump et al., 2015).

As a simple robustness check to the pairwise correlation results provided is reported in column [2]. For instance, this column shows the correlations of these labor market outcomes with the presence, rather than the performance, of community banks in a state. The presence of CBs is proxied by the the share of total state deposits held by community banks. Given that it does not seem that the relationship between cost efficiency and the market presence of CBs can explain their individual correlations with socioeconomic outcomes, these findings strengthen the motivation to further investigate how the performance of community banking markets can impact socioeconomic outcomes of their markets. Hence, my future research will continue to explore such findings using more sophisticated models and larger sample periods.

Furthermore, future research should also investigate the performance and composition of banking markets individually. ${ }^{18}$ For instance, the variation of the cost efficiency of CBs within a state is also an interesting study to be conducted. Nonetheless, the investigation of this result goes beyond the scope of this paper.

\footnotetext{
${ }^{18}$ Minuci and Schuh (2021) provide a great example of the analysis of individual state banking markets by studying the West Virginia banking industry.
} 


\subsection{Conclusion}

This paper highlights the importance of re-evaluating a banks' performance and its determinants after experiencing regulatory and market composition changes. Results show that the relative core cost efficiency of banks has worsened in the past two decades. Moreover, we observe that the relationship between cost-efficiency with bank age, regulator, and ownership remains significant but now has the opposite sign. Lastly, customer characteristics also emerge as significantly correlated with bank performance.

The relevance of a bank's cost efficiency to regional economic activity comes from its association with its ability to provide liquidity services to its customers during recessions. Using a weighted average of the cost efficiency of U.S. CBs, a micro-macro approach, this research is the first to provide a proxy for the ability of banking markets across U.S. states to provide liquidity to its clients in periods of downturn in economic activity. Nevada, Massachusetts, and Utah are the most efficient U.S. state banking markets and are, on average, nearly twice as efficient as the least efficient states (New Mexico, Alaska, and Arizona).

This discrepancy in the performance of CBs across state banking markets hints that a broader investigation of CBs' performance and their economic impact across different states deserves attention. To take a first attempt at answering to this question, using pairwise correlations, this research reports that the aggregate cost efficiency of state community banking markets is associated with both lower unemployment and job destruction rates. These results are the first step towards better understanding the relationship between the performance of regional banking markets and regional socioeconomic outcomes across U.S. states. Nonetheless, future work requires further exploration of the causality channels connecting these variables.

There is promising work to be done towards improving the understanding of the determinants of the cost efficiency of community banks and banking markets. For instance, at the regional level future research involves evaluating the performance of community banking markets over time and their main determinants. At the bank-level, a promising study involves exploring the factors that 
have driven the variation of cost efficiency within and across CBs in the past decades. This study's results hint that better understanding such questions can help direct future regulations and improve the ability of the financial system to positively impact socioeconomic outcomes across U.S. states. 
Table 3.1: Banking Market State-Level Characteristics

\begin{tabular}{lcccc}
\hline Variable & Mean & Std. Dev. & Max. & Min. \\
\hline N. of Banks Operating in State & 600.63 & 494.24 & 2420.00 & 28.00 \\
State avg. Branches by Bank & 12.85 & 6.43 & 32.92 & 4.31 \\
State Share of CBs & 0.69 & 0.18 & 0.94 & 0.23 \\
State Share of CBs' Branches & 0.29 & 0.17 & 0.69 & 0.05 \\
State CBs Deposit Share & 0.18 & 0.14 & 0.60 & 0.00 \\
State Loans to Assets Ratio & 0.59 & 0.07 & 0.71 & 0.21 \\
State Bank HHI & 303.31 & 240.31 & 1372.84 & 49.02 \\
State CBs' HHI & 138.19 & 203.91 & 1027.37 & 9.10 \\
\hline
\end{tabular}

$\mathrm{N}=306$. 
Table 3.2: Descriptive Statistics of the Cost Function Main Variables

\begin{tabular}{lcc}
\hline Bank Type: & $\frac{\mathrm{CBs}}{}$ & \\
Variable & Mean & Std. Dev. \\
\hline $\mathrm{w}_{1}:$ Price of Labor & 69.552 & 28.634 \\
$\mathrm{w}_{2}:$ Price of Physical Capital & .504 & 26.878 \\
$\mathrm{w}_{3}:$ Price of Purchased Funds & .034 & .230 \\
$\mathrm{w}_{4}:$ Price of Core Deposits & .010 & .731 \\
$\mathrm{y}_{1}:$ Consumer Loans & .031 & .049 \\
$\mathrm{y}_{2}:$ C\&I Loans & .076 & .064 \\
$\mathrm{y}_{3}:$ Residential Real Estate & .197 & .150 \\
$\mathrm{y}_{4}:$ Commercial Real Estate & .262 & .144 \\
$\mathrm{y}_{5}:$ Other Loans & .056 & .087 \\
$\mathrm{z}_{1}:$ Notion of Off-balance Sheet Act. & .009 & .093 \\
$\mathrm{z}_{2}:$ Financial Equity Capital & .119 & .069 \\
$v:$ State Share of Nonperforming Loans & .013 & .007 \\
\hline Observations & 131,062 & \\
Number of banks & 6,335 & \\
Max. number of periods per bank & 24 & \\
\hline
\end{tabular}

Input price variables are reported in real dollars.

$y_{\#}$ and $z_{\#}$ are reported as share of total bank assets.

Input prices are flow variables and, thus, are annualized annualized.

For banks operating in more than one state, nonperforming loans represent the weighted average of the share of nonporfoling loans across all the states it operates in. 
Table 3.3: Panel Bank-Level Regression Estimates

\begin{tabular}{|c|c|}
\hline & Total Costs \\
\hline Price of Labor & $\begin{array}{c}-23.78^{* * * *} \\
(1.959)\end{array}$ \\
\hline Price of Physical Capital & $\begin{array}{c}-24.91 * * * \\
(7.616)\end{array}$ \\
\hline Price of Purchased Funds & $\begin{array}{c}1.229 * * * \\
(.373)\end{array}$ \\
\hline Consumer Loans & $\begin{array}{c}1.610 \\
(1.024)\end{array}$ \\
\hline C\&I Loans & $\begin{array}{c}-2.610^{* * * *} \\
(.744)\end{array}$ \\
\hline Residential Real Estate & $\begin{array}{c}-6.667 * * \\
(2.720)\end{array}$ \\
\hline Commercial Real Estate & $\begin{array}{l}-1.493 \\
(2.014)\end{array}$ \\
\hline Other Loans & $\begin{array}{c}-4.202^{* *} \\
(1.808)\end{array}$ \\
\hline Notion of Off-balance Sheet Act. & $\begin{array}{c}6.101 * * * \\
(1.648)\end{array}$ \\
\hline State Share of Nonperforming Loans & $\begin{array}{c}-0.0985^{* * * *} \\
(.00528)\end{array}$ \\
\hline Constant & $\begin{array}{c}46.10 \\
(49.45)\end{array}$ \\
\hline St. Dev. of Residuals of $u_{i}$ & $\begin{array}{l}.3296 \\
5337\end{array}$ \\
\hline Observations & 131062 \\
\hline Number of banks & 6335 \\
\hline Max. number of periods per bank & 24 \\
\hline
\end{tabular}

Standard errors in parentheses

$* p<0.10, * * p<0.05, * * * p<0.01$

Total costs and input prices are normalized by the average cost per dollar of core deposits. Total costs, output quantities, and off-balance sheet activities are normalized by financial equity capital. The second-order translog and fourier-flexible terms are omited and can be provided upon request. 
Table 3.4: Cost Efficiency of U.S. Community Banks

\begin{tabular}{lcccc}
\hline & Mean & Std. Dev. & Min. & Max. \\
\hline 95th winsorization & .613 & .170 & .358 & 1.000 \\
99th winsorization & .456 & .146 & .187 & 1.000 \\
\hline
\end{tabular}


Figure 3.1: Histograms of Cost Efficiency of U.S. Community Banks

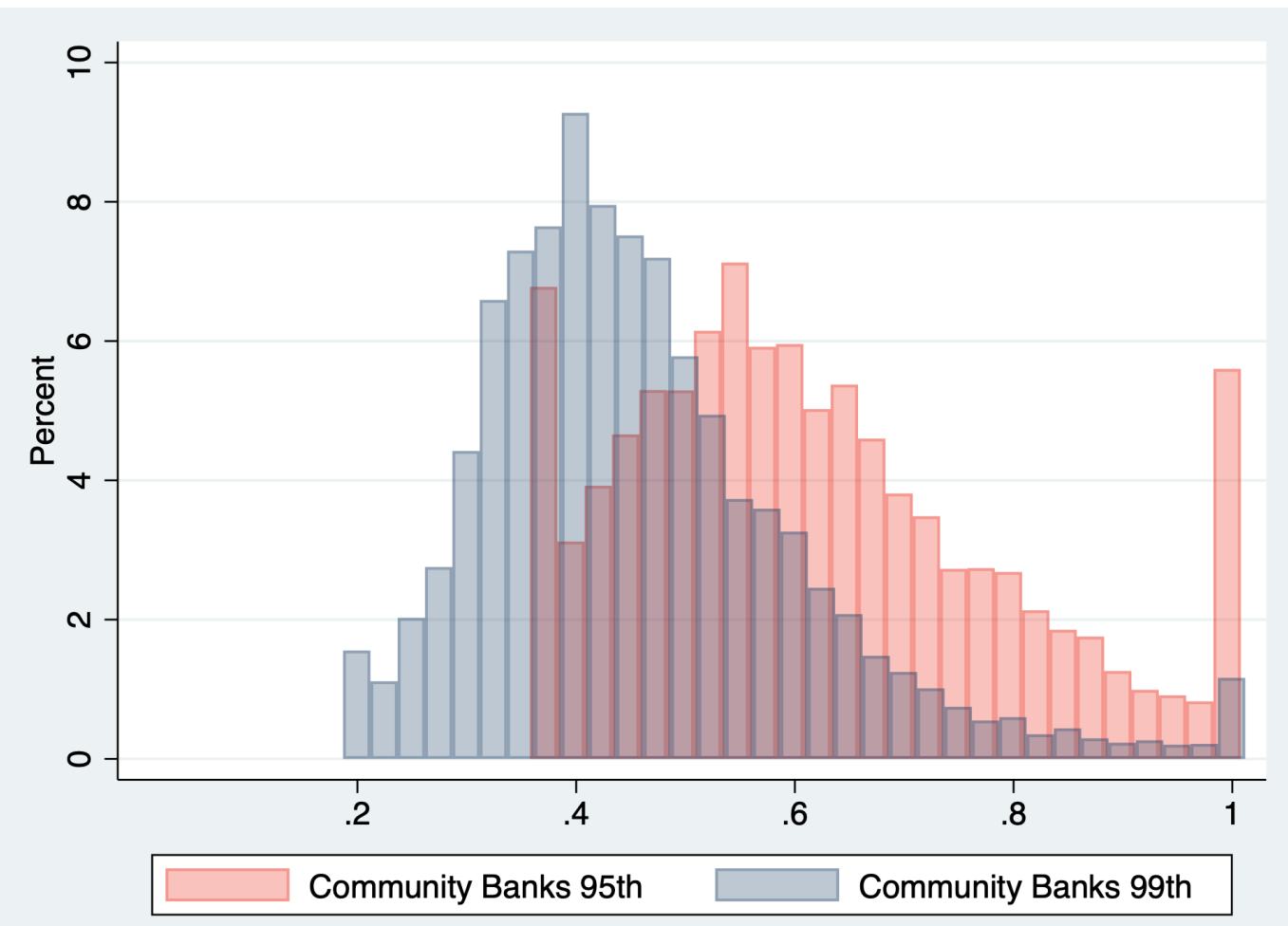


Table 3.5: Banking and Regional Characteristics of U.S. Community Banks

\begin{tabular}{lcc}
\hline Variable & Mean & Std. Dev. \\
\hline $\bar{X}_{i}:$ Banking Characteristics & & \\
Total Assets (in millions) & 210.201 & 187.635 \\
Owner: Bank Holding Company & .788 & .408 \\
Age: Less than 10yrs old & .179 & .384 \\
Age: 10 - 20 yrs old & .106 & .308 \\
Age: Older than 20 yrs old & .715 & .452 \\
Savings Association & .119 & .324 \\
Relevance: Loans & .608 & .166 \\
Relevance: Purchased Funds & .103 & .080 \\
Relevance: Off-Balance Sheet Act. & .016 & .106 \\
Share of Nonperforming Loans & .015 & .020 \\
Regulator: FDIC & .653 & .470 \\
Regulator: OCC & .224 & .411 \\
$\bar{G}_{i}:$ Regional Characteristics & & \\
CBs Operating in 2 or 3 States & .071 & .256 \\
Customer Market Size & .027 & .025 \\
State Share of College Graduates & .077 & .038 \\
State Share of Pop. 65yrs and older & .142 & .016 \\
Branch Spec.: Agriculture & .227 & .419 \\
State Share of CB Deposits & .313 & .178 \\
State CBs' HHI & 230.477 & 287.293 \\
State HHI (All Banks) & 897.464 & 712.230 \\
\hline Observations & 5,984 & \\
\hline
\end{tabular}

This analysis focus only on banks characterized as CBs consistently throughout the 6 years of data this study considers. 
Table 3.6: Micro-Level Cost Efficiency of U.S. Banks

\begin{tabular}{|c|c|c|}
\hline Sample: & CBs & CSMBs \\
\hline \multicolumn{3}{|l|}{ Dep Var: CB's Cost-Efficiency } \\
\hline Owner: Bank Holding Company & $\begin{array}{c}-.0421 * * * \\
(.00533)\end{array}$ & $\begin{array}{c}-.0426 * * * \\
(.00551)\end{array}$ \\
\hline Age: Less than 10 Years Old & $\begin{array}{l}.0349 * * * \\
(.00591)\end{array}$ & $\begin{array}{l}.0364 * * * \\
(.00625)\end{array}$ \\
\hline Age: 10 - 20 Years Old & $\begin{array}{l}.0226 * * * \\
(.00631)\end{array}$ & $\begin{array}{l}.0259 * * * \\
(.00674)\end{array}$ \\
\hline Relevance: Loans & $\begin{array}{l}.205^{* * * *} \\
(.0144)\end{array}$ & $\begin{array}{l}.173 * * * \\
(.0152)\end{array}$ \\
\hline Relevance: Purchased Funds & $\begin{array}{l}.158 * * * \\
(.0297)\end{array}$ & $\begin{array}{l}.151 * * * \\
(.0308)\end{array}$ \\
\hline Relevance: Off-Balance Sheet Act. & $\begin{array}{c}-.137 * * * \\
(.0191)\end{array}$ & $\begin{array}{c}-.119 * * * \\
(.0221)\end{array}$ \\
\hline Share of Nonperforming Loans & $\begin{array}{c}-.935 * * * \\
(.135)\end{array}$ & $\begin{array}{c}-.902 * * * \\
(.134)\end{array}$ \\
\hline Savings Association & $\begin{array}{l}.0405 * * * \\
(.00727)\end{array}$ & $\begin{array}{l}.0444 * * * \\
(.00773)\end{array}$ \\
\hline Regulator: FDIC & $\begin{array}{c}.00926 * * * \\
(.00350)\end{array}$ & $\begin{array}{c}.00801 * * \\
(.00369)\end{array}$ \\
\hline Geo Expansion: Operates in 2 or 3 States & $\begin{array}{c}-.0444 * * * \\
(.00606)\end{array}$ & \\
\hline Customer Market Size & $\begin{array}{c}.602 * * * \\
(.115)\end{array}$ & $\begin{array}{c}.731 * * * \\
(.130)\end{array}$ \\
\hline State Share of Graduates & $\begin{array}{l}.756 * * * \\
(.0717)\end{array}$ & $\begin{array}{l}.790 * * * \\
(.0757)\end{array}$ \\
\hline State Share of Pop. 65+ Years & $\begin{array}{c}.540 * * * \\
(.127)\end{array}$ & $\begin{array}{c}.568 * * * \\
(.134)\end{array}$ \\
\hline Branch Spec.: Agriculture & $\begin{array}{l}.0315 * * * \\
(.00441)\end{array}$ & $\begin{array}{c}.0328 * * * \\
(.00461)\end{array}$ \\
\hline State Share of CB Deposits & $\begin{array}{l}.128 * * * \\
(.0171)\end{array}$ & $\begin{array}{l}.127 * * * \\
(.0183)\end{array}$ \\
\hline State Deposit HHI & $\begin{array}{l}.163 * * * \\
(.0337)\end{array}$ & $\begin{array}{l}.159 * * * \\
(.0358)\end{array}$ \\
\hline State CBs’ Deposit HHI & $\begin{array}{c}-.105 \\
(.0785)\end{array}$ & $\begin{array}{c}-.0516 \\
(.0815)\end{array}$ \\
\hline Constant & $\begin{array}{l}.0545 * \\
(.0287)\end{array}$ & $\begin{array}{l}.0558 * \\
(.0303)\end{array}$ \\
\hline Observations & 5984 & 5562 \\
\hline Adjusted $R^{2}$ & .192 & .176 \\
\hline
\end{tabular}

Standard errors in parentheses.

$* p<0.10, * * p<0.05, * * * p<0.01$

${ }^{1}$ Bank size is not included since the cost efficiency estimation accounts for scale bias.

2 Prior to running the regression, HHI variables were multiplied by 10,000 as traditionally done in the literature. 
Figure 3.2: State Weighted Average of Cost Efficiency of Community Banks by State

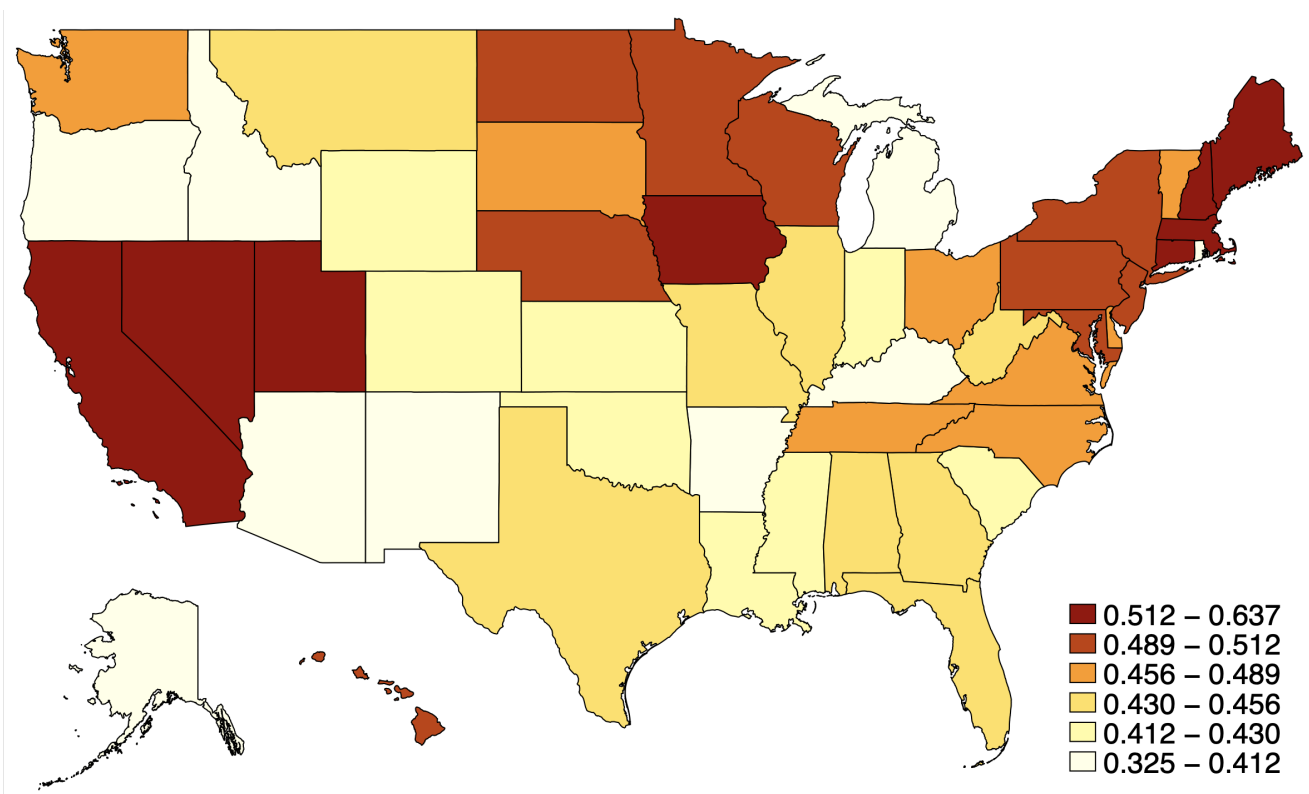

Note: Color bins indicate different quantiles of the distribution. 
Table 3.7: State-Level Correlation Matrix

\begin{tabular}{lccccc}
\hline State Variables & {$[1]$} & {$[2]$} & {$[3]$} & [4] & [5] \\
\hline Market Cost Efficiency for CBs [1] & & & & & \\
CB's Share of State Deposits [2] & $-0.195^{*}$ & & & & \\
Real Income per Capita Growth [3] & 0.049 & $-0.161^{*}$ & & & \\
Unemployment Rate [4] & $-0.175^{*}$ & $-0.2268^{*}$ & $-0.187^{*}$ & & \\
Job Destruction Rate [5] & $-0.208^{*}$ & 0.019 & $-0.264^{*}$ & $0.181^{*}$ & \\
Job Creation Rate [6] & -0.068 & $-0.375^{*}$ & 0.131 & $0.162^{*}$ & $0.393^{*}$ \\
\hline
\end{tabular}

All variables above represent the 6 years average of data from 2013 to 2018 .

Sample size is 51 . 


\section{Bibliography}

Adrian, T. and Shin, H. S. (2009). Money, liquidity, and monetary policy. American Economic Review, 99(2):600-605.

Aguirregabiria, V., Clark, R., and Wang, H. (2016). Diversification of geographic risk in retail bank networks: Evidence from bank expansion after the riegle-neal act. The RAND Journal of Economics, 47(3):529-572.

Ahmad, A. H., Green, C., and Jiang, F. (2020). Mobile money, financial inclusion and development: A review with reference to african experience. Journal of Economic Surveys, 34(4):753792.

Alessandrini, P., Fratianni, M., and Zazzaro, A. (2009). The Changing Geography of Banking and Finance. Springer Verlag.

Appalachian Regional Commission (2015). Appalachia then and now: Examining changes to the Appalachian region since 1965. Technical report, Center for Regional Economic Competitiveness and West Virginia University.

Arango, C., Huynh, K. P., and Sabetti, L. (2015). Consumer payment choice: Merchant card acceptance versus pricing incentives. Journal of Banking \& Finance, 55:130-141. Global Governance and Financial Stability.

Arestis, P. and Mihailov, A. (2011). Classifying monetary economics: Fields and methods from past to future. Journal of Economic Surveys, 25(4):769-800. 
Assaf, A. G., Berger, A. N., Roman, R. A., and Tsionas, M. G. (2019). Does efficiency help banks survive and thrive during financial crises? Journal of Banking \& Finance, 106:445 - 470.

Badger, E. (2021). West virginia has everyone's attention. What does it really need? The New York Times.

Bafumi, J. and Gelman, A. (2006). Fitting multilevel models when predictors and group effects correlate. SSRN.

Ball, L. (2012). Short-run money demand. Journal of Monetary Economics, 59(7):622-633.

Barnett, W. A., Fisher, D., and Serletis, A. (1992). Consumer theory and the demand for money. Journal of Economic Literature, 30(4):2086-2119.

Barth, J. R., Hilliard, J., Jahera Jr., J. S., and Sun, Y. (2016). Alabama banking: The state of the state's banking industry. Technical report, Government \& Economic Development Institute of Auburn University Outreach.

Bauer, P. W. and Hancock, D. (1993). The efficiency of the federal reserve in providing check processing services. Journal of Banking \& Finance, 17(2):287 - 311.

Berger, A. N. (1993). "Distribution-free" estimates of efficiency in the U.S. banking industry and tests of the standard distributional assumptions. Journal of Productivity Analysis, 4(3):261-292.

Berger, A. N. (2003). The economic effects of technological progress: Evidence from the banking industry. Journal of Money, Credit and Banking, 35(2):141-176.

Berger, A. N. and Black, L. K. (2020). Small business lending: The roles of technology and regulation from pre-crisis to crisis to recovery. In Berger, A. N., Molyneux, P., and Wilson, J. O. S., editors, The Oxford Handbook of Banking, chapter 14. Oxford University Press.

Berger, A. N., Bouwman, C. H. S., and Kim, D. (2017). Small bank comparative advantages in alleviating financial constraints and providing liquidity insurance over time. The Review of Financial Studies, 30(10):3416-3454. 
Berger, A. N., Chen, R. R., El Ghoul, S., and Guedhami, O. (2020). Who wins and who loses from bank geographic deregulation? Analysis of financially constrained and unconstrained firms. Journal of Corporate Finance, 65:101775.

Berger, A. N. and DeYoung, R. (1997). Problem loans and cost efficiency in commercial banks. Journal of Banking \& Finance, 21(6):849 - 870.

Berger, A. N. and Humphrey, D. B. (1997). Efficiency of financial institutions: International survey and directions for future research. European Journal of Operational Research, 98(2):175-212.

Berger, A. N., Imbierowicz, B., and Rauch, C. (2016). The roles of corporate governance in bank failures during the recent financial crisis. Journal of Money, Credit and Banking, 48(4):729-770.

Berger, A. N. and Mester, L. J. (1997). Inside the black box: What explains differences in the efficiencies of financial institutions? Journal of Banking \& Finance, 21(0):895-947.

Berger, A. N. and Mester, L. J. (2003). Explaining the dramatic changes in performance of us banks: Technological change, deregulation, and dynamic changes in competition. Journal of Financial Intermediation, 12(1):57 - 95.

Berger, A. N. and Sedunov, J. (2017). Bank liquidity creation and real economic output. Journal of Banking \& Finance, 81:1 - 19.

Bernard, A. B. and Jensen, J. B. (1999). Exceptional exporter performance: Cause, effect, or both? Journal of International Economics, 47:1-25.

Brown, J. R., Cookson, J. A., and Heimer, R. Z. (2019). Growing up without finance. SSRN, pages $1-76$.

Burdett, K., Trejos, A., and Wright, R. (2017). A new suggestion for simplifying the theory of money. Journal of Economic Theory, 172:423-450. 
Carbó-Valverde, S. and Liñares-Zegarra, J. M. (2011). How effective are rewards programs in promoting payment card usage? Empirical evidence. Journal of Banking \& Finance, 35(12):32753291.

Carpenter, C. W., Mencken, F. C., Tolbert, C. M., and Lotspeich, M. (2020). Locally owned bank concentration and business start-ups and closures in U.S. metropolitan, micropolitan, and rural counties from 1980-2010. Review of Regional Studies, 50(1):12 - 42.

Ching, A. T. and Hayashi, F. (2010). Payment card rewards programs and consumer payment choice. Journal of Banking \& Finance, 34(8):1773-1787. New Contributions to Retail Payments: Conference at Norges Bank (Central Bank of Norway) 14-15 November 2008.

Dalziel, P. (2000). On the evolution of money and its implications for price stability. Journal of Economic Surveys, 14(4):373-393.

Danisewicz, P., McGowan, D., Onali, E., and Schaeck, K. (2018). The real effects of banking supervision: Evidence from enforcement actions. Journal of Financial Intermediation, 35:86101.

David, B., Abel, F., and Patrick, W. (2016). Debit card and demand for cash. Journal of Banking \& Finance, 73:55-66.

Demombynes, G. and Thegeya, A. (2012). Kenya's mobile revolution and the promise of mobile savings. World Bank Policy Research Working Papers, 1(5988):1-32.

DeYoung, R. (1997). A diagnostic test for the distribution-free efficiency estimator: An example using U.S. commercial bank data. European Journal of Operational Research, 98(2):243 - 249.

DeYoung, R., Gron, A., Torna, G., and Winton, A. (2015). Risk overhang and loan portfolio decisions: Small business loan supply before and during the financial crisis. The Journal of Finance, 70(6):2451-2488. 
DeYoung, R. and Torna, G. (2013). Nontraditional banking activities and bank failures during the financial crisis. Journal of Financial Intermediation, 22:397-421.

Duygan-Bump, B., Levkov, A., and Montoriol-Garriga, J. (2015). Financing constraints and unemployment: Evidence from the great recession. Journal of Monetary Economics, 75:89 - 105.

FDIC (2012). Community banking study. Federal Deposit Insurance Corporation, pages 1-102.

Flannery, M. J. (1982). Retail bank deposits as quasi-fixed factors of production. The American Economic Review, 72(3):527-536.

Foster, K., Greene, C., and Stavins, J. (2020). The 2019 Survey of Consumer and Payment Choice: Summary results. Technical Report 20-3, Federal Reserve Bank of Atlanta: Research Data Reports.

Frame, W. S. and White, L. J. (2004). Empirical studies of financial innovation: Lots of talk, little action? Journal of Economic Literature, 42(1):116-144.

Fujiki, H. and Tanaka, M. (2009). Demand for currency, new technology and the adoption of electronic money: Evidence using individual household data. IMES Discussion Paper Series, 09-E-27.

Gelman, A., Shor, B., Bafumi, J., and Park, D. (2008). Rich state, poor state, red state, blue state: What's the matter with Connecticut? Quarterly Journal of Political Science, 2(4):345-367.

Goetz, M. R., Laeven, L., and Levine, R. (2016). Does the geographic expansion of banks reduce risk? Journal of Financial Economics, 120:346-362.

Greenbaum, S. I., Thakor, A. V., and Boot, A. (2019). Contemporary financial intermediation. Academic Press, London, 4 edition.

Hannan, T. H. (1979). Limit pricing and the banking industry. Journal of Money, Credit and Banking, 11(4):438-446. 
Hannan, T. H. and McDowell, J. M. (1984). The determinants of technology adoption: The case of the banking firm. The RAND Journal of Economics, 15(3):328-335.

Hannan, T. H. and McDowell, J. M. (1987). Rival precedence and the dynamics of technology adoption: An empirical analysis. Economica, 54(214):155-171.

Hausman, J. A. and Taylor, W. E. (1981). Panel data and unobservable individual effects. Econometrica, 49(6):1377-1398.

Herath, J., Schaeffer, P., and Gebremedhin, T. (2013). Employment change in LDs of West Virginia: A dynamic spatial shift- share analysis. American Journal of Rural Development, 1(5):99105.

Hughes, J. P., Lang, W., Mester, L. J., and Moon, C.-G. (1996). Efficient banking under interstate branching. Journal of Money, Credit and Banking, 28(4):1045-1071.

Humphrey, D. B., Kim, M., and Vale, B. (2001). Realizing the gains from electronic payments: Costs, pricing, and payment choice. Journal of Money, Credit and Banking, 33(2):216-234.

Isserman, A. and Rephann, T. (1995). The economic effects of the Appalachian Regional Commission: An empirical assessment of 26 years of regional development planning. Journal of the American Planning Association, 61(3):345-364.

Jack, W., Suri, T., and Townsend, R. M. (2010). Monetary theory and electronic money: Reflections on the Kenyan experience. Economic Quarterly - Federal Reserve Bank of Richmond, 96(3):83-122.

Johnson, C. A. and Rice, T. (2008). Assessing a decade of interstate bank branching. Washington Lee Law Review, 65(1):73 - 127.

Judd, J. P. and Scadding, J. L. (1982). The search for a stable money demand function: A survey of the post-1973 literature. Journal of Economic Literature, 20(3):993-1023. 
Khan, U. and Ozel, N. B. (2016). Real activity forecasts using loan portfolio information. Journal of Accounting Research, 54(3):895-937.

Lagos, R., Rocheteau, G., and Wright, R. (2017). Liquidity: A new monetarist perspective. Journal of Economic Literature, 55(2):371-440.

Le Maux, L. (2014). Cantillon and hume on money and banking: The foundations of two theoretical traditions. Journal of Economic Surveys, 28(5):956-970.

Leventakis, J. A. and Brissimis, S. N. (1991). Instability of the U.S. money demand function. Journal of Economic Surveys, 5(2):131-161.

Lewis, R. L. and Billings, D. B. (1997). Appalachian culture and economic development: A retrospective view on the theory and literature. Journal of Appalachian Studies, 3(1):3-42.

Lucas Jr., R. E. and Nicolini, J. P. (2015). On the stability of money demand. Journal of Monetary Economics, 73:48-65. Carnegie-Rochester-NYU Conference Series on Public Policy "Monetary Policy: An Unprecedented Predicament" held at the Tepper School of Business, Carnegie Mellon University, November 14-15, 2014.

McCarthy, R. (2014). Why abundant coal may have 'cursed' the Appalachian economy. The Washington Post.

Minuci, E. (2021). A state-level analysis of the cost efficiency of U.S. community banks. Working Paper, 72(2):1-34.

Minuci, E. and Schuh, S. (2021). How are West Virginia banks different? Working Paper, pages $1-66$.

Mitchell, K. and Onvural, N. M. (1996). Economies of scale and scope at large commercial banks: Evidence from the fourier flexible functional form. Journal of Money, Credit and Banking, 28(2):178-199. 
Moulton, B. R. (1990). An illustration of a pitfall in estimating the effects of aggregate variables on micro units. Review of Economics and Statistics, 72(2):334-338.

Nguyen, H.-L. Q. (2019). Are credit markets still local? Evidence from bank branch closings. American Economic Journal: Applied Economics, 11(1):1-32.

Ouma, S. A., Odongo, T. M., and Were, M. (2017). Mobile financial services and financial inclusion: Is it a boon for savings mobilization? Review of Development Finance, 7(1):29-35. Financial Sector Development in Africa: An Overview.

Park, K. and Pennacchi, G. (2008). Harming depositors and helping borrowers: The disparate impact of bank consolidation. The Review of Financial Studies, 22(1):1-40.

Radecki, L. J. (1998). The expanding geographic reach of retail banking markets. Economic Policy Review, 4(2):15-34.

Samolyk, K. A. (1994). Banking conditions and regional economic performance evidence of a regional credit channel. Journal of Monetary Economics, 34(2):259 - 278.

Schuh, S., Shy, O., and Stavins, J. (2013). Who gains and who loses from credit card payments? Theory and calibrations. Public Policy Discussion Papers, 10(03):1-61.

Schuh, S. and Stavins, J. (2010). Why are (some) consumers (finally) writing fewer checks? The role of payment characteristics. Journal of Banking \& Finance, 34(8):1745-1758.

Sherman, M. (2009). A short history of financial deregulation in the United States. Center for Economic and Policy Research, pages 1-15.

Shim, J. (2019). Loan portfolio diversification, market structure and bank stability. Journal of Banking \& Finance, 104:103-115.

Simon, J., Smith, K., and West, T. (2010). Price incentives and consumer payment behaviour. Journal of Banking \& Finance, 34(8):1759-1772. New Contributions to Retail Payments: Conference at Norges Bank (Central Bank of Norway) 14-15 November 2008. 
Singh, S. (1999). Electronic money: Understanding its use to increase the effectiveness of policy. Telecommunications Policy, 23(10):753-773.

Singh, S. (2004). Impersonalisation of electronic money: Implications for bank marketing. International Journal of Bank Marketing, 22(7):504-521.

Stephens, H. H. and Deskins, J. (2018). Economic distress and labor market participation. American Journal of Agricultural Economics, 0(0):1-21.

Stephens, H. M. and Partridge, M. D. (2011). Do entrepreneurs enhance economic growth in lagging regions? Growth and Change, 42(4):431-465.

Stephens, H. M., Partridge, M. D., and Faggian, A. (2013). Innovation, entrepreneurship and economic growth in lagging regions. Journal of Regional Science, 53(5):778-812.

Tabak, B. M., Fazio, D. M., and Cajueiro, D. O. (2011). The effects of loan portfolio concentration on Brazilian banks' return and risk. Journal of Banking \& Finance, 35(11):3065-3076.

Theil, H. (1971). Principles of Econometrics. John Wiley \& Sons, New York.

Tobin, J. (1992). Money. Cowles Foundation for Research in Economics, 1013.

Tokle, R. J. and Tokle, J. G. (2000). The influence of credit union and savings and loan competition on bank deposit rates in Idaho and Montana. Review of Industrial Organization, 17(4):427-439.

Wallace, N. (2018). The case for imposing cashlessness: A review article. Journal of Economic Literature, 56(4):1587-91.

Walter, J. R. (1989). Monetary aggregates: A user's guide. FRB Richmond Economic Review, 75(1):20-28.

Williams, B. (2016). The impact of non-interest income on bank risk in Australia. Journal of Banking \& Finance, 73:16 - 37. 
Zingales, L. (2015). Presidential address: Does finance benefit society? The Journal of Finance, 70(4):1327-1363. 


\section{G Additional Tables and Figures for Chapter 2}

Figure G.1: WV and US* Bank Expenses by Market, 2017

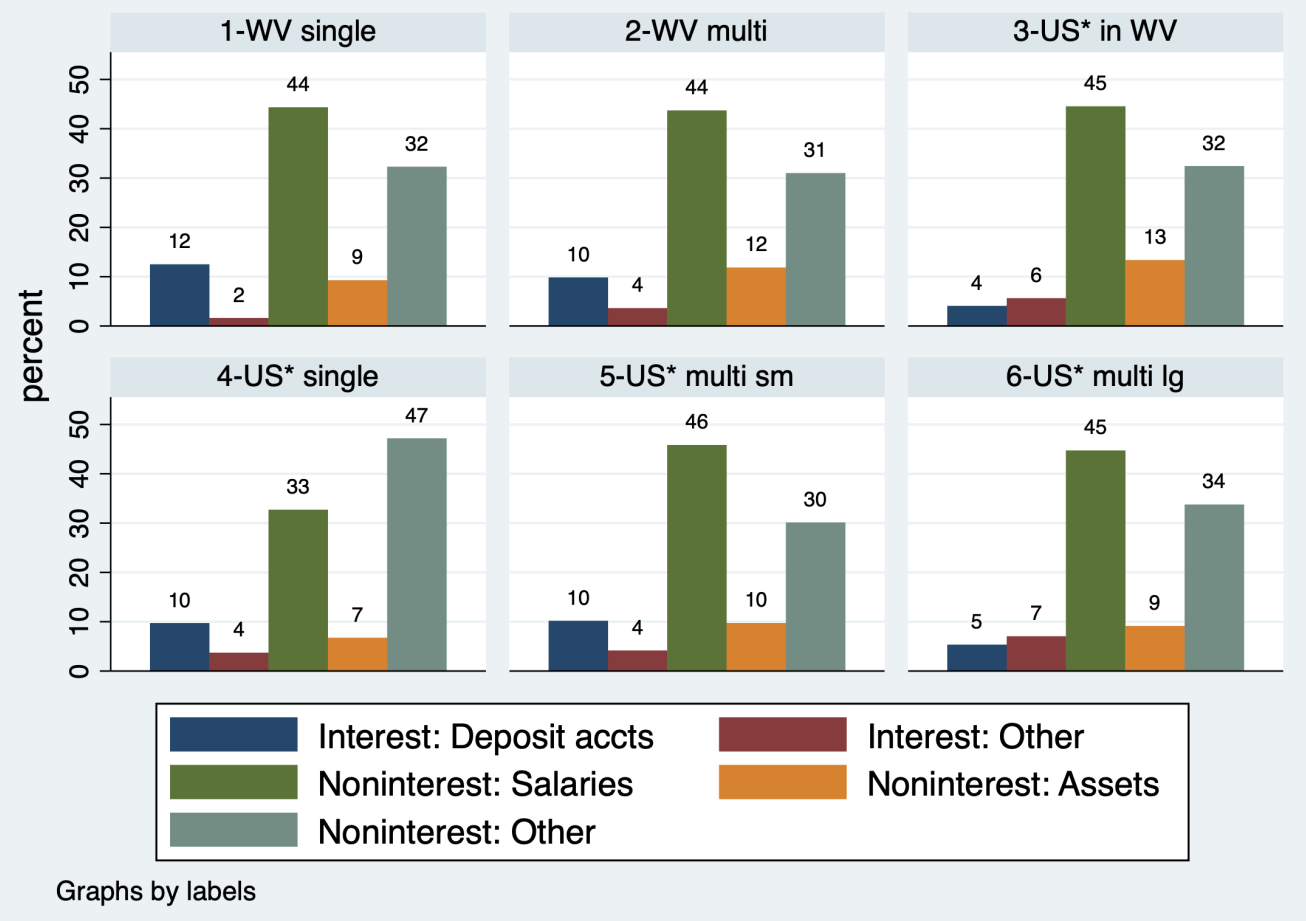


Figure G.2: WV and US* Interest Rates on Deposits

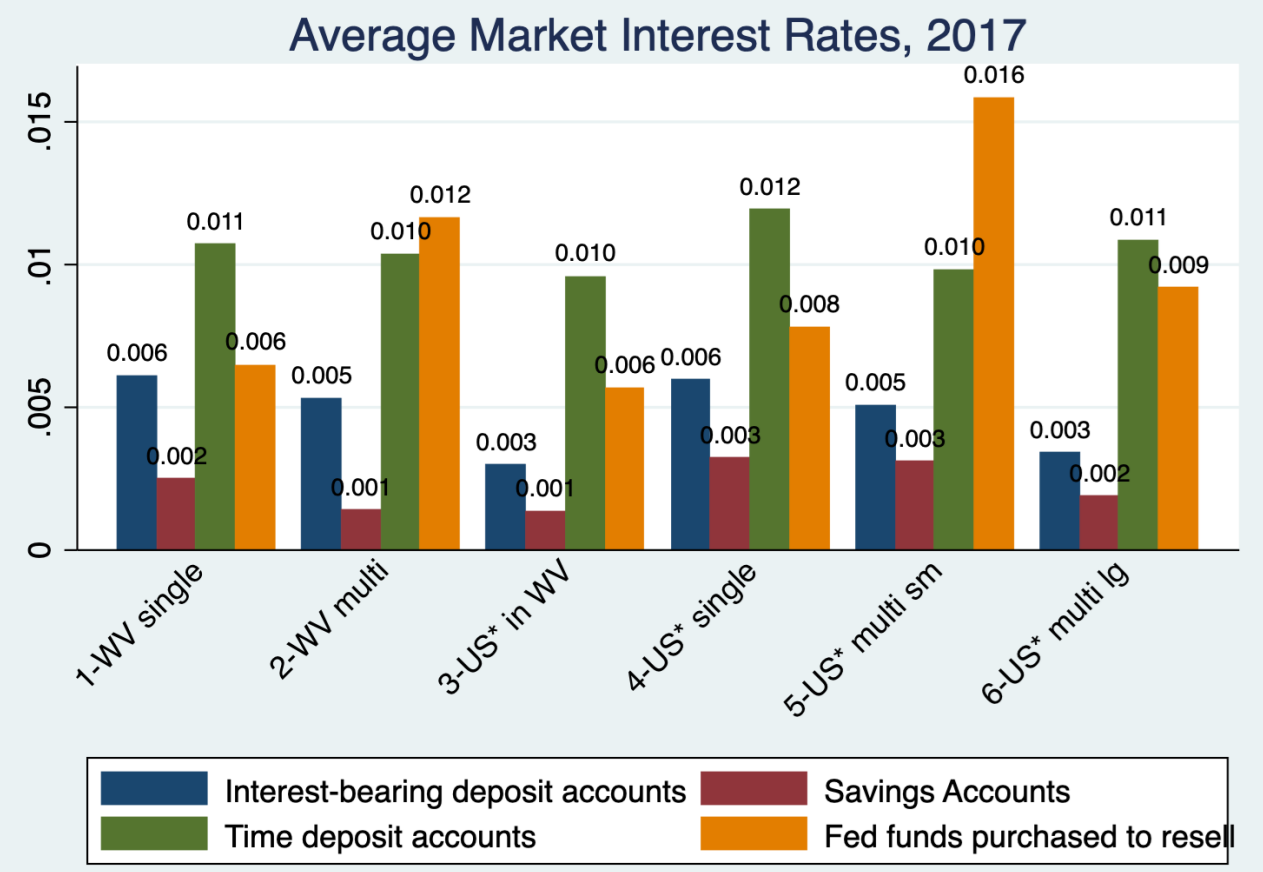


Figure G.3: WV and US* Interest Rates on Loans

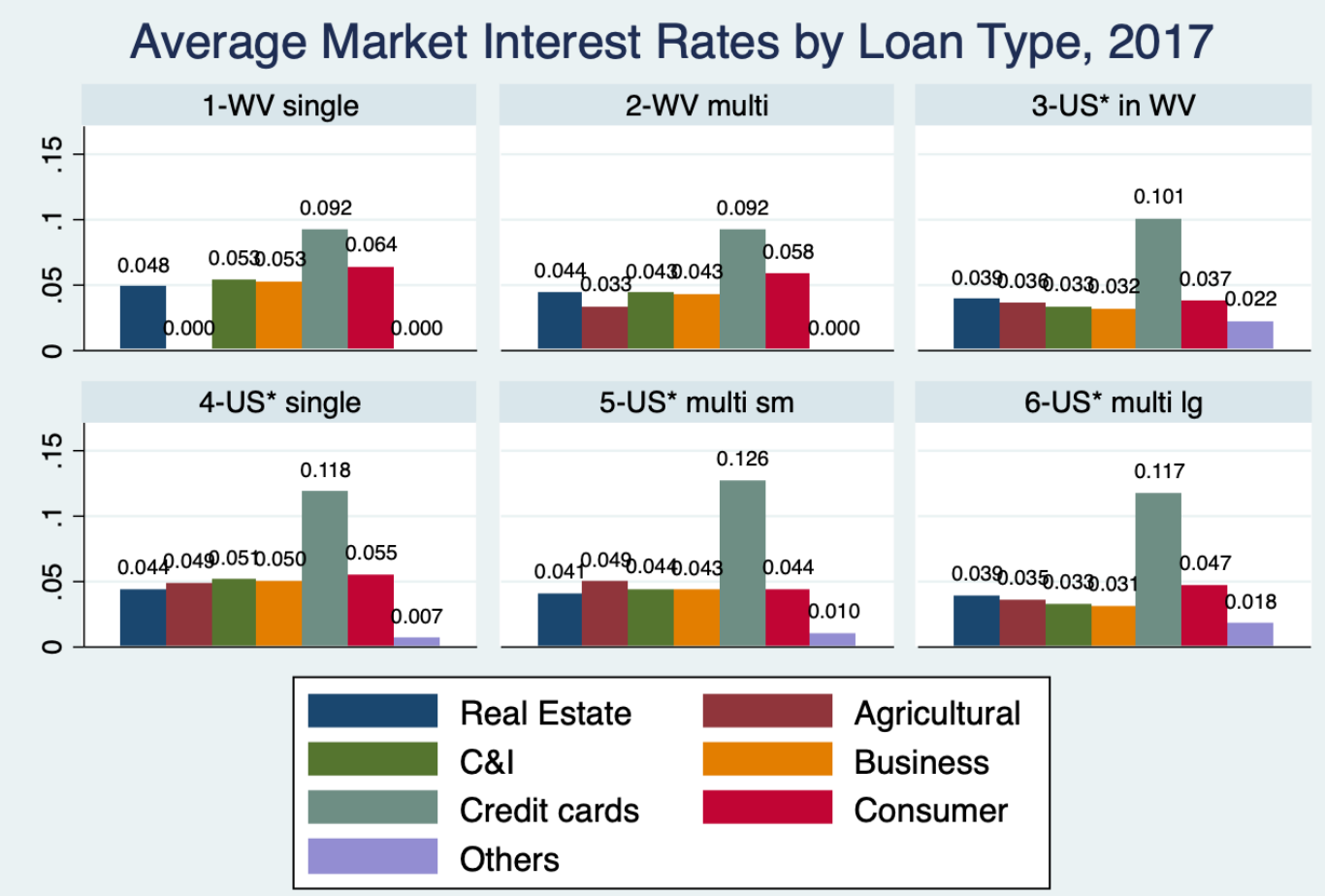

Graphs by (first) labels 


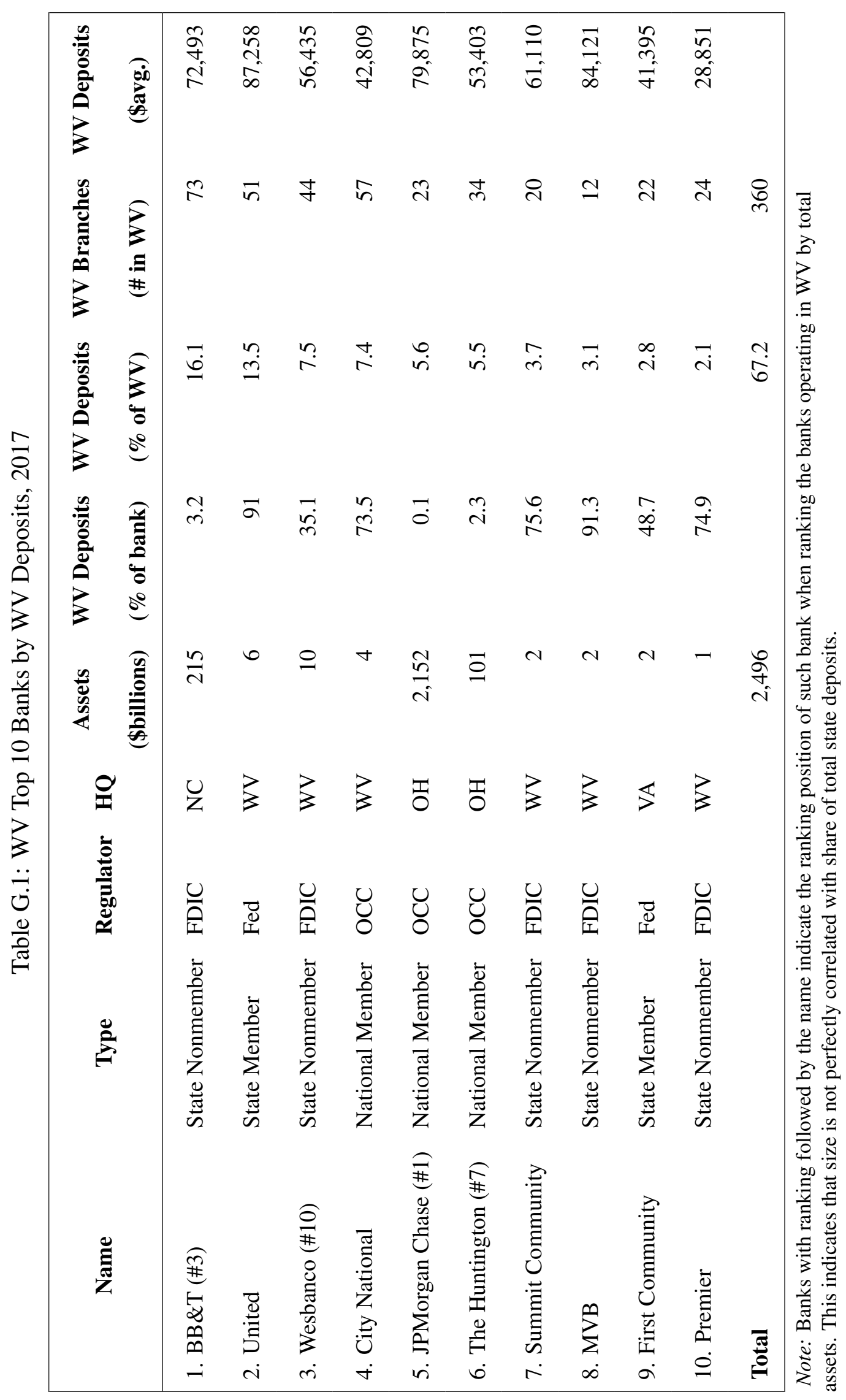




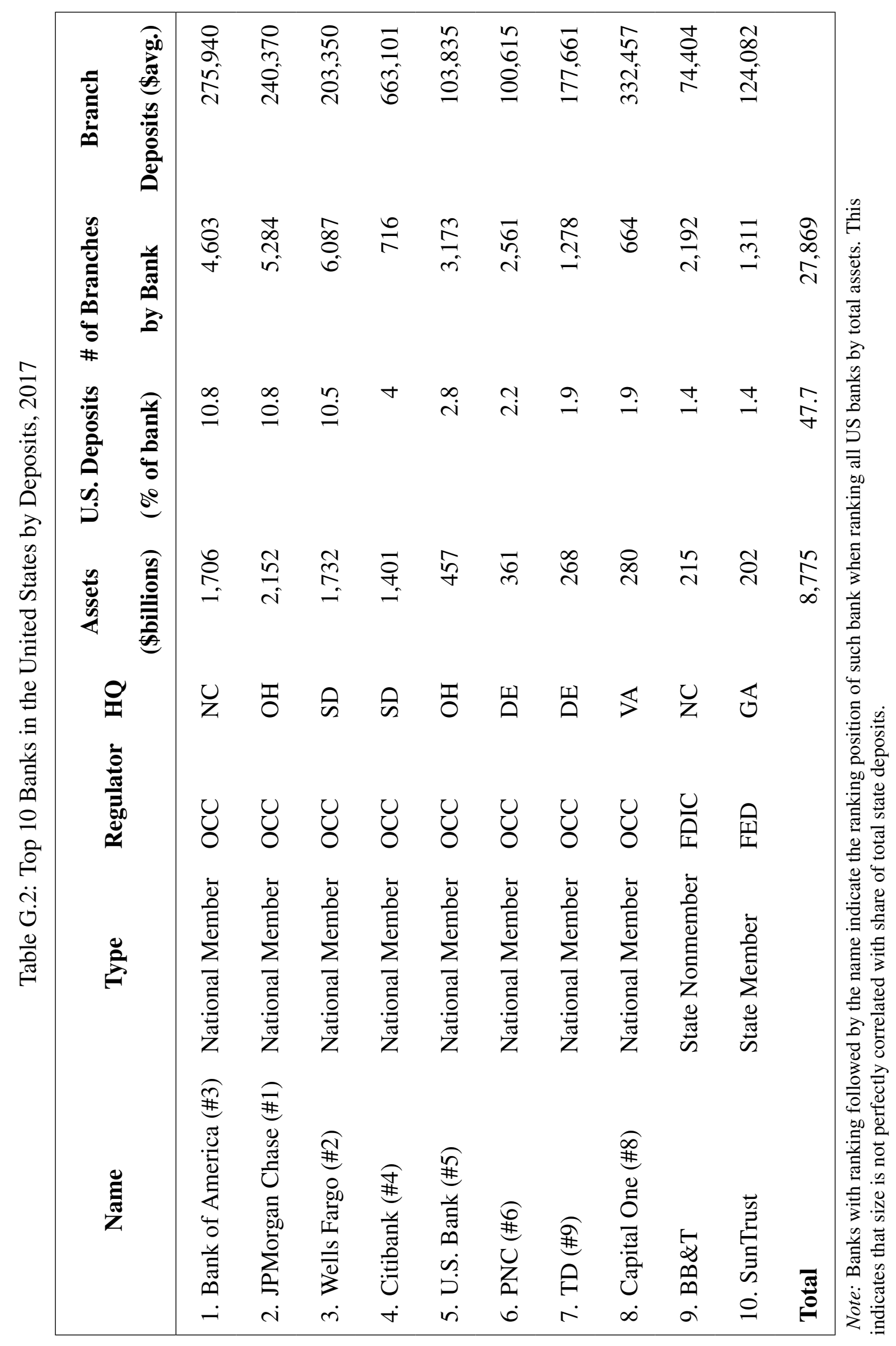




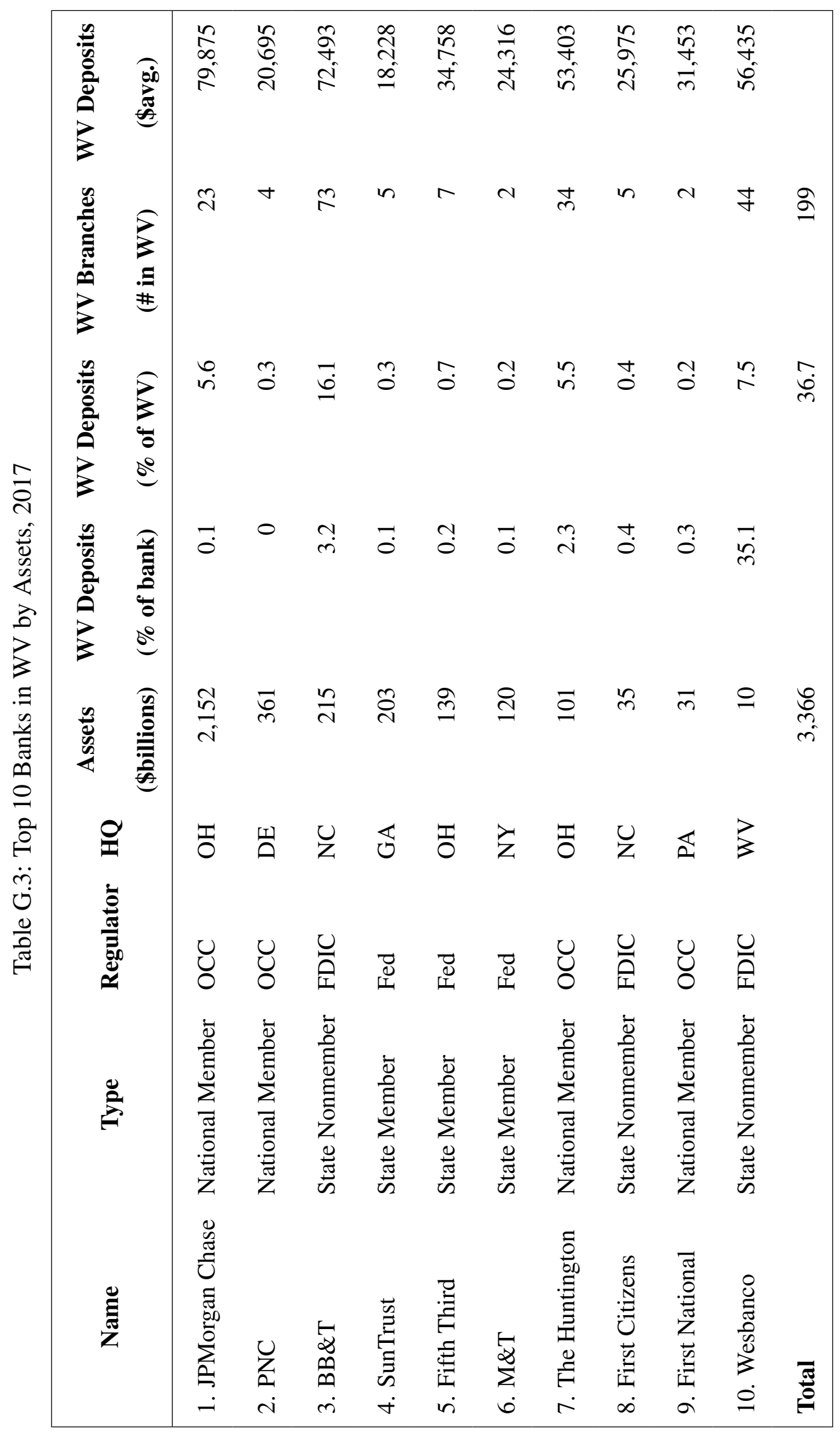




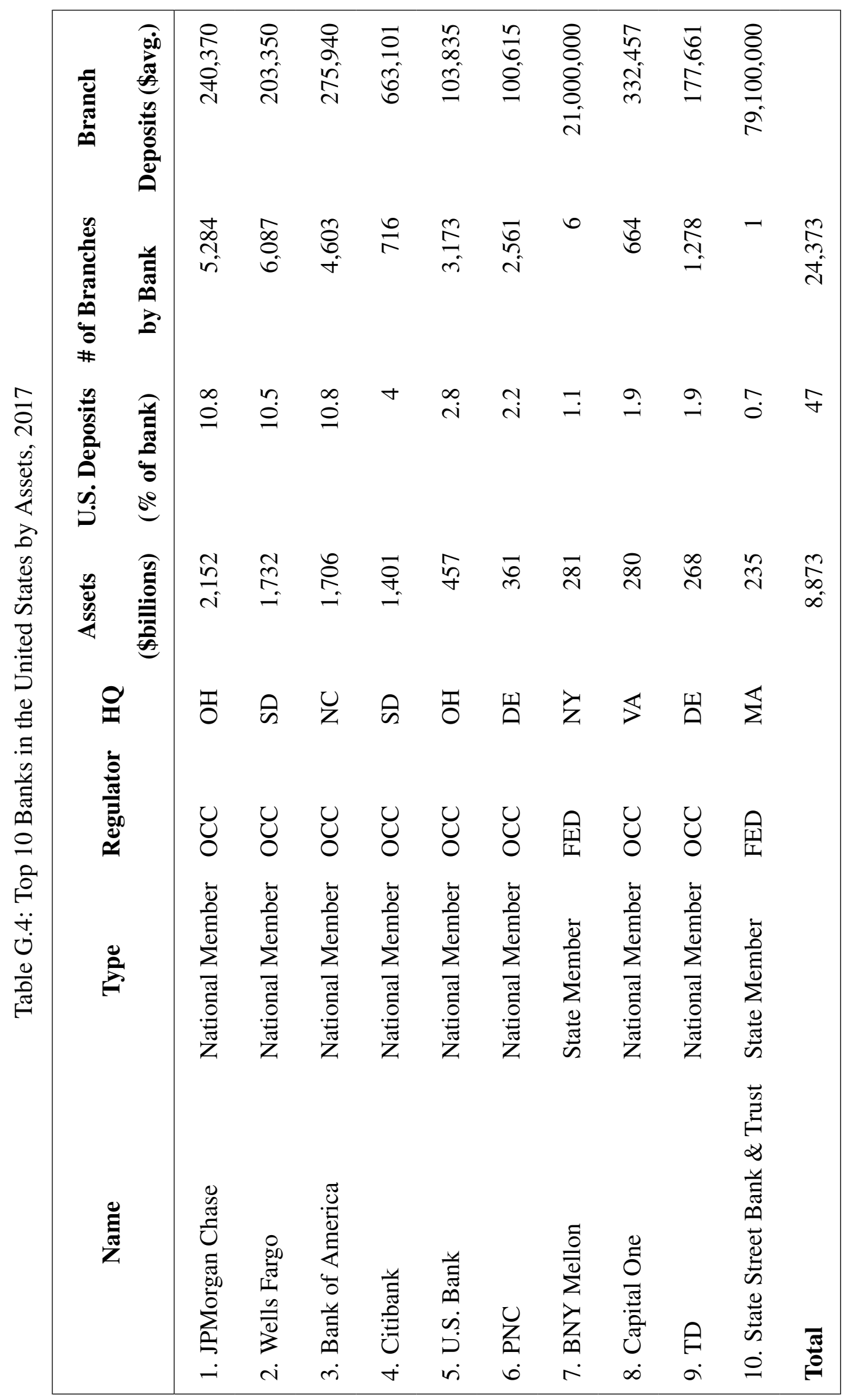


Table G.1: Data Description

\begin{tabular}{|c|c|c|}
\hline Variable Name & Unit & Description \\
\hline \multicolumn{3}{|l|}{ Explanatory Variables: } \\
\hline \multicolumn{3}{|l|}{ Bank Specific Variables: } \\
\hline WV & dummy & $\begin{array}{l}\text { Equal to } 1 \text { if bank's headquarter is located in West Vir- } \\
\text { ginia }\end{array}$ \\
\hline US* & dummy & $\begin{array}{l}\text { Equal to } 1 \text { if bank's headquarter is located outside of } \\
\text { West Virginia }\end{array}$ \\
\hline Class: Nonmember & dummy & $\begin{array}{l}\text { Equal to } 1 \text { if bank is a commercial bank, state chartered, } \\
\text { Fed nonmember, and supervised by the FDIC or OCC. }\end{array}$ \\
\hline Class: State Member & dummy & $\begin{array}{l}\text { Equal to } 1 \text { if bank is a commercial or savings bank, state } \\
\text { chartered, Fed member, and supervised by the Federal } \\
\text { Reserve. }\end{array}$ \\
\hline Class: Savings Bank & dummy & $\begin{array}{l}\text { Equal to } 1 \text { if bank is a savings bank, state chartered, and } \\
\text { supervised by the FDIC. }\end{array}$ \\
\hline Owned: Multi-BHC & dummy & $\begin{array}{l}\text { Equal to } 1 \text { if bank is owned by a multi-bank holding } \\
\text { company. }\end{array}$ \\
\hline Owned: Single-BHC & dummy & $\begin{array}{l}\text { Equal to } 1 \text { if bank is equal to } 1 \text { if bank is owned by a } \\
\text { single-bank holding company. }\end{array}$ \\
\hline Reg. by FDIC & dummy & Primarily Regulated by the FDIC. \\
\hline Age: $0-10$ yrs & dummy & $\begin{array}{l}\text { Equal to } 1 \text { if bank has been insured by the FDIC for } 10 \\
\text { or less years. }\end{array}$ \\
\hline Age: $10-20 \mathrm{yrs}$ & dummy & $\begin{array}{l}\text { Equal to } 1 \text { if bank has been insured by the FDIC for } \\
\text { more than } 10 \text { but less than } 20 \text { years. }\end{array}$ \\
\hline Bank Size: Nat. Share of Deposits & bps & Bank's share of total national deposits. \\
\hline \multicolumn{3}{|l|}{ Market Characteristics: } \\
\hline Market Size: Share of States & bps & Share of states banks operate in (counts DC as a state). \\
\hline Market Size: Share of Pop. & bps & $\begin{array}{l}\text { Share of national population in the bank's main market } \\
\text { area. The market area of a bank includes all the states } \\
\text { in which the bank has branches located in. }\end{array}$ \\
\hline Avg. Branch Dep. & $\log$ dollars & The log of the average branch deposits of the bank. \\
\hline Dependent Variables: & & \\
\hline
\end{tabular}




\begin{tabular}{|c|c|c|}
\hline Variable Name & Unit & Description \\
\hline \multicolumn{3}{|c|}{ Liabilities and Capital: } \\
\hline IntAccts & bps & $\begin{array}{l}\text { Bank's interest-bearing deposits in domestic and for- } \\
\text { eign offices as a share of the sum of the bank's total } \\
\text { liabilities and total equity capital. }\end{array}$ \\
\hline NonIntAccts & bps & $\begin{array}{l}\text { Bank's sum of total demand deposits and noninterest- } \\
\text { bearing time and savings deposits in domestic and for- } \\
\text { eign offices as a share of the sum of the bank's total } \\
\text { liabilities and total equity capital. }\end{array}$ \\
\hline Frepp & bps & $\begin{array}{l}\text { Bank's federal funds purchased and securities sold un- } \\
\text { der agreements to repurchase as a share of the sum of } \\
\text { the bank's total liabilities and total equity capital. }\end{array}$ \\
\hline OthBorFunds & bps & $\begin{array}{l}\text { Bank's other borrowed funds as a share of the sum of } \\
\text { the bank's total liabilities and total equity capital..Other } \\
\text { borrowed funds exclude deposits, federal funds pur- } \\
\text { chased, securities sold under agreements to repurchase } \\
\text { in domestic offices of the bank, and trading liabilities. }\end{array}$ \\
\hline OthLiab & bps & $\begin{array}{l}\text { Bank's other liabilities as a share of the sum of the } \\
\text { bank's total liabilities and total equity capital. Other } \\
\text { liabilities include trading liabilities, subordinated debt, } \\
\text { liability on acceptances executed and outstanding, in- } \\
\text { terest and other expenses accrued and unpaid, and other } \\
\text { liabilities. }\end{array}$ \\
\hline Capital & bps & $\begin{array}{l}\text { Bank's total equity capital as a share of the sum of the } \\
\text { bank's total liabilities and total equity capital. }\end{array}$ \\
\hline \multicolumn{3}{|l|}{ Deposits: } \\
\hline TransDep & bps & $\begin{array}{l}\text { Bank's transaction deposits as a share of the bank's total } \\
\text { assets. }\end{array}$ \\
\hline MMDAs & bps & $\begin{array}{l}\text { Bank's deposits from money market deposit accounts } \\
\text { (MMDAs) as a share of the bank's total assets. }\end{array}$ \\
\hline
\end{tabular}




\begin{tabular}{|c|c|c|}
\hline Variable Name & Unit & Description \\
\hline OthSav & bps & $\begin{array}{l}\text { Bank's deposits from savings accounts excluding MM- } \\
\text { DAs as a share of the bank's total assets. }\end{array}$ \\
\hline TmDep0-250k & bps & $\begin{array}{l}\text { Bank's time deposits under } \$ 250,000 \text { as a share of the } \\
\text { bank's total assets. }\end{array}$ \\
\hline TmDep250k & bps & $\begin{array}{l}\text { Bank's time deposits over or equal to } \$ 250,000 \text { as a } \\
\text { share of the bank's total assets. }\end{array}$ \\
\hline \multicolumn{3}{|l|}{ Assets: } \\
\hline RealEstLns & bps & $\begin{array}{l}\text { Bank's real estate loans as a share of the bank's total } \\
\text { assets. }\end{array}$ \\
\hline CILns & bps & $\begin{array}{l}\text { Bank's commercial and industrial loans as a share of } \\
\text { the bank's total assets. }\end{array}$ \\
\hline CrCdLns & bps & $\begin{array}{l}\text { Bank's credit card loans as a share of the bank's total } \\
\text { assets. }\end{array}$ \\
\hline OthConsLns & bps & $\begin{array}{l}\text { Bank's other consumer loans as a share of the bank's } \\
\text { total assets. Other loans represent all consumer loans } \\
\text { minus credit card loans. }\end{array}$ \\
\hline OthLns & bps & Bank's other loans as a share of the bank's total assets. \\
\hline Sct & bps & Bank's securities as a share of the bank's total assets. \\
\hline ChBal & bps & $\begin{array}{l}\text { Bank's cash \& balances due from depository institu- } \\
\text { tions as a share of the bank's total assets. }\end{array}$ \\
\hline Frepo & bps & $\begin{array}{l}\text { Bank's federal funds sold and reverse repurchase as a } \\
\text { share of the bank's total assets. }\end{array}$ \\
\hline OthAssets & bps & $\begin{array}{l}\text { Bank's other assets as a share of the bank's total assets. } \\
\text { Other assets include bank premises and fixed assets, di- } \\
\text { rect and indirect investments in real estate, trading ac- } \\
\text { count assets, intangible assets, and other assets. }\end{array}$ \\
\hline \multicolumn{3}{|l|}{ Real Estate Loans: } \\
\hline ConstDev & bps & $\begin{array}{l}\text { Bank's construction and land development loans se- } \\
\text { cured by real estate held in domestic offices as a share } \\
\text { of bank's total real estate loans. }\end{array}$ \\
\hline
\end{tabular}




\begin{tabular}{|c|c|c|}
\hline Variable Name & Unit & Description \\
\hline Agric & bps & $\begin{array}{l}\text { Bank's loans secured by farmland held in domestic of- } \\
\text { fices as a share of bank's total real estate loans. }\end{array}$ \\
\hline 1-4FamRes & bps & $\begin{array}{l}\text { Bank's Total loans secured by } 1-4 \text { family residential } \\
\text { properties held in domestic offices as a share of bank's } \\
\text { total real estate loans. }\end{array}$ \\
\hline 5+FamRes & bps & $\begin{array}{l}\text { Bank's multifamily ( } 5 \text { or more) residential property } \\
\text { loans secured by real estate held in domestic offices as } \\
\text { a share of bank's total real estate loans. }\end{array}$ \\
\hline NonResNonFarm & bps & $\begin{array}{l}\text { Bank's nonresidential loans, excluding farm loans, pri- } \\
\text { marily secured by real estate held in domestic offices as } \\
\text { a share of bank's total real estate loans. }\end{array}$ \\
\hline Foreign & bps & $\begin{array}{l}\text { Bank's loans secured by Real Estate held in foreign of- } \\
\text { fices as a share of bank's total real estate loans. }\end{array}$ \\
\hline \multicolumn{3}{|c|}{ Income: Interest and Noninterest } \\
\hline i.RE & bps & $\begin{array}{l}\text { Bank's interest and fee income on loans secured by real } \\
\text { estate in domestic offices as a share of bank's total in- } \\
\text { come. }\end{array}$ \\
\hline i.CI & bps & $\begin{array}{l}\text { Bank's interest and fee income on commercial and in- } \\
\text { dustrial (C\&I) loans in domestic offices as a share of } \\
\text { bank's total income. }\end{array}$ \\
\hline i.Cons & bps & $\begin{array}{l}\text { Bank's interest and fee income on consumer loans in } \\
\text { domestic offices as a share of bank's total income. } \\
\text { These include credit card and other consumer loans } \\
\text { listed in Assets. }\end{array}$ \\
\hline i.OthLns & bps & $\begin{array}{l}\text { Bank's interest and fee income on other loans as a share } \\
\text { of bank's total income. Other loans include loans to for- } \\
\text { eign governments and official institutions, and all other } \\
\text { loans in domestic offices. }\end{array}$ \\
\hline
\end{tabular}


...continued

\begin{tabular}{|c|c|c|}
\hline Variable Name & Unit & Description \\
\hline i.Sct & bps & $\begin{array}{l}\text { Bank's interest and dividend on securities as a share } \\
\text { of bank's total income. This variable includes inter- } \\
\text { est and dividend income from U.S. Treasury securities, } \\
\text { U.S. government agency and corporation obligations, } \\
\text { securities issued by states and political subdivisions, } \\
\text { other domestic debt securities, foreign debt securities, } \\
\text { and equity securities (including investments in mutual } \\
\text { funds). Excludes interest income from securities held } \\
\text { in trading accounts. }\end{array}$ \\
\hline i.FFandOth & bps & $\begin{array}{l}\text { Bank's other interest income as a share of bank's total } \\
\text { income. Other interest income includes interest income } \\
\text { from lease financing receivables, on balances due from } \\
\text { depository institutions, from assets held in trading ac- } \\
\text { counts, on federal funds sold and securities purchased } \\
\text { under agreements to resell, and other interest income. }\end{array}$ \\
\hline Nonint. & bps & $\begin{array}{l}\text { Bank's noninterest income as a share of bank's to- } \\
\text { tal income. Noninterest income includes income from } \\
\text { fiduciary activities, plus service charges on deposit ac- } \\
\text { counts in domestic offices, plus trading gains (losses) } \\
\text { and fees from foreign exchange transactions, plus other } \\
\text { foreign transaction gains (losses), plus other gains } \\
\text { (losses) and fees from trading assets and liabilities. }\end{array}$ \\
\hline \multicolumn{3}{|c|}{ Noninterest Income: } \\
\hline FiducAcvt & bps & $\begin{array}{l}\text { Bank's income from fiduciary activities as share of } \\
\text { bank's total noninterest income. }\end{array}$ \\
\hline DepAcctsChg & bps & $\begin{array}{l}\text { Bank's income from service charges on deposit account } \\
\text { as share of bank's total noninterest income. }\end{array}$ \\
\hline Trad & bps & $\begin{array}{l}\text { Bank's income from trading revenue as share of bank's } \\
\text { total noninterest income. }\end{array}$ \\
\hline
\end{tabular}




\begin{tabular}{|c|c|c|}
\hline Variable Name & Unit & Description \\
\hline Invest & bps & $\begin{array}{l}\text { Bank's income from other investments as share of } \\
\text { bank's total noninterest income. Other investments in- } \\
\text { clude venture capital revenue, fees and commissions } \\
\text { from securities brokerage, investment banking, advi- } \\
\text { sory, and underwriting fees and commissions, and oth- } \\
\text { ers. }\end{array}$ \\
\hline ServFees & bps & $\begin{array}{l}\text { Bank's net servicing fees as share of bank's total nonin- } \\
\text { terest income. Net servicing fees include income from } \\
\text { servicing real estate mortgages, credit cards, and other } \\
\text { financial assets held by others. }\end{array}$ \\
\hline Securiz & bps & $\begin{array}{l}\text { Bank's net securitization income as share of bank's to- } \\
\text { tal noninterest income. Securization income includes } \\
\text { net gains (losses) on assets sold in securitization trans- } \\
\text { actions. }\end{array}$ \\
\hline SalesAssets & bps & $\begin{array}{l}\text { Bank's income from sales of loans and leases, other real } \\
\text { estate owned, and other assets as share of bank's total } \\
\text { noninterest income. }\end{array}$ \\
\hline OthNonii & bps & $\begin{array}{l}\text { Bank's other noninterest income as share of bank's total } \\
\text { noninterest income. }\end{array}$ \\
\hline \multicolumn{3}{|c|}{ Expenses: Interest and Noninterest: } \\
\hline i.ExpDep & bps & $\begin{array}{l}\text { Bank's total interest expense on deposits as a share of } \\
\text { bank's total expenses. }\end{array}$ \\
\hline i.ExpOth & bps & $\begin{array}{l}\text { Bank's total interest expense excluding interest expense } \\
\text { on deposits as a share of bank's total expenses. }\end{array}$ \\
\hline non-i.Sal & bps & $\begin{array}{l}\text { Bank's salaries and employee benefits as a share of } \\
\text { bank's total expenses. }\end{array}$ \\
\hline non-i.As & bps & $\begin{array}{l}\text { Bank's expenses of premises and fixed assets (net of } \\
\text { rental income) as a share of bank's total expenses. }\end{array}$ \\
\hline
\end{tabular}




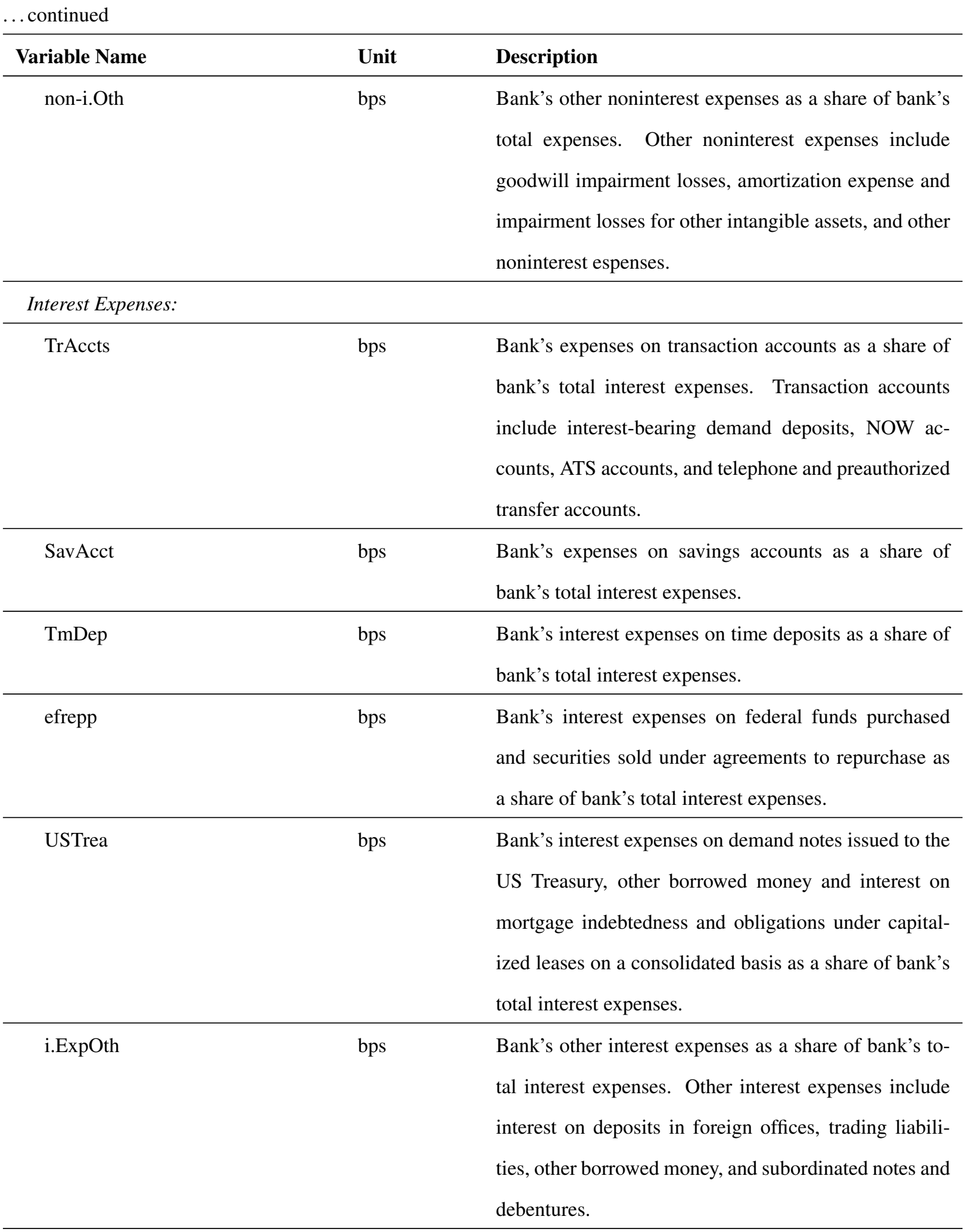

Performance Variables: 


\begin{tabular}{|c|c|c|}
\hline Variable Name & Unit & Description \\
\hline ROA & bps & $\begin{array}{l}\text { Bank's net income after taxes and extraordinary items } \\
\text { (annualized) as a percent of average total asset. }\end{array}$ \\
\hline EfficR & bps & $\begin{array}{l}\text { Bank's noninterest expense less amortization of intan- } \\
\text { gible assets as a percent of net interest income plus non- } \\
\text { interest income. This ratio measures the proportion of } \\
\text { net operating revenues that are absorbed by overhead } \\
\text { expenses, so that a lower value indicates greater effi- } \\
\text { ciency. }\end{array}$ \\
\hline NetIntMg & bps & $\begin{array}{l}\text { Bank's total interest income less total interest expense } \\
\text { (annualized) as a percent of average earning assets. }\end{array}$ \\
\hline Tier1Cap & bps & $\begin{array}{l}\text { Bank's tier } 1 \text { (core) capital as a percent of average total } \\
\text { assets minus ineligible intangibles. Tier } 1 \text { (core) capital } \\
\text { includes common equity plus noncumulative perpetual } \\
\text { preferred stock plus minority interests in consolidated } \\
\text { subsidiaries less goodwill and other ineligible intangi- } \\
\text { ble assets. }\end{array}$ \\
\hline nLnsAsR & bps & $\begin{array}{l}\text { Bank's loan and lease financing receivables, net of un- } \\
\text { earned income, allowances, and reserves, as a percent } \\
\text { of total assets. }\end{array}$ \\
\hline nLnsDepR & bps & $\begin{array}{l}\text { Bank's loans and lease financing receivables net of un- } \\
\text { earned income, allowances and reserves as a percent of } \\
\text { total deposits. }\end{array}$ \\
\hline EqAsR & bps & Bank's total equity capital as a percent of total assets. \\
\hline DebtEqR & bps & Bank's total liability as a percent of total equity capital. \\
\hline \multicolumn{3}{|l|}{ Z Variables: } \\
\hline inc & $\log$ units & Log of state real income per capita. \\
\hline pop5yrg & bps & State 5-year population growth rate. \\
\hline busi5yrg & bps & State 5 -year business growth rate. \\
\hline age65over & bps & State share of population over 65 years old. \\
\hline DebtInc.pc & dollars & State household debt to income per capita ratio. \\
\hline
\end{tabular}




\begin{tabular}{cll}
... continued & & \\
\hline Variable Name & Unit & Description \\
\hline RPP & index & State regional price parity (proxy for state inflation). \\
\hline SBPI & index & Small Business Policy Index which measures how well \\
& & a state, through public policies, creates a nurturing en- \\
& & vironment for entrepreneurial activity and the develop- \\
& & ment of small businesses. \\
\hline GeoExpansion.st & bps & Average geographical expansion of banks in a state. \\
\hline SB.st & bps & Share of savings banks in a state. \\
\hline
\end{tabular}

